\title{
GEOTHERMAL AND HEAVY-OIL RESOURCES IN TEXAS
}

\section{TOPICAL REPORT}

\author{
By Steven J. Seni and Timothy G. Walter
}

January 1994

\section{DISCLAIMER}

This report was prepared as an account of work sponsored by an agency of the United States Government. Neither the United States Government nor any agency thereof, nor any of their employees, makes any warranty, express or implied, or assumes any legal liability or responsibility for the accuracy, completeness, or usefulness of any information, apparatus, product, or process disclosed, or represents that its use would not infringe privately owned rights. Reference herein to any specific commercial product, process, or service by trade name, trademark, manufacturer, or otherwise does not necessarily constitute or imply its endorsement, recommendation, or favoring by the United States Government or any agency thereof. The views and opinions of authors expressed herein do not necessarily state or reflect those of the United States Government or any agency thereof.

\author{
NV \\ Work Performed Under Contract DE-FC07-85 10412 \\ For \\ U. S. Department of Energy \\ Office of Industrial Technologies \\ Washington, D.C.
}

\section{By}

Bureau of Economic Geology

The University of Texas at Austin Austin, Texas 78713-7508 


\section{DISCLAIMER}

Portions of this document may be illegible in electronic image products. Images are produced from the best available original document. 


\section{Contents}

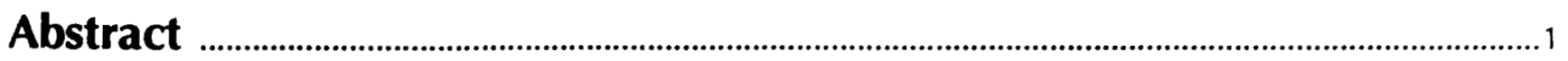

Introduction ....................................................................................................................................

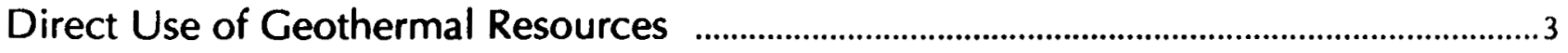

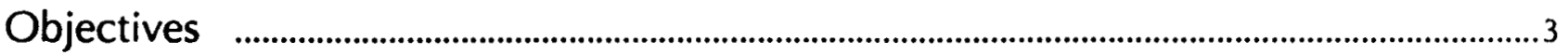

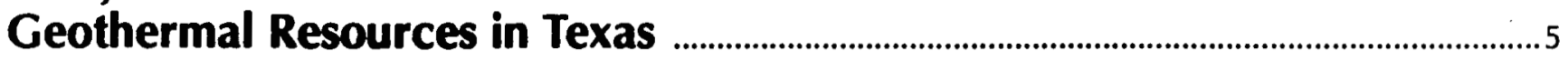

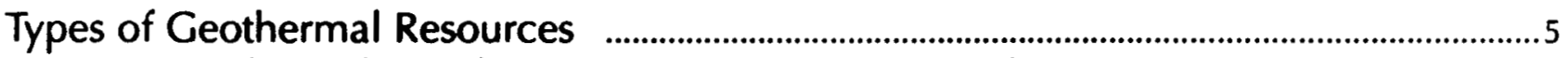

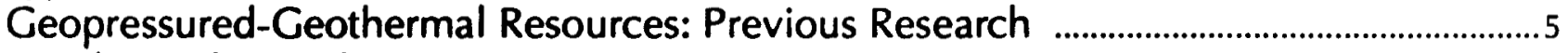

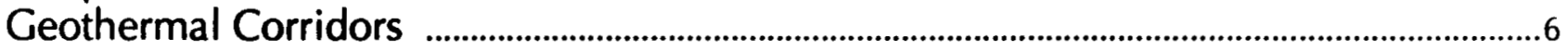

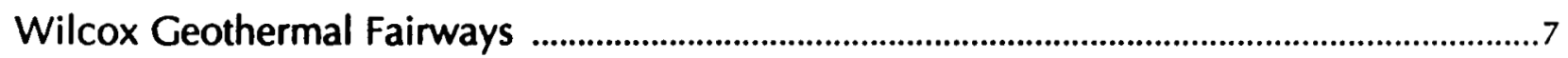

Model I -South Texas upper Wilcox Fairways ......................................................................................

Model II-Lower Wilcox De Witt, Colorado, and Harris Fairways ........................................................11

Frio Geothermal Fairways ...............................................................................................................11

Model III—Hidalgo and Armstrong Fairways..............................................................................11

Model IV - Corpus Christi Fairway ....................................................................................................11

Model V_Brazoria and Matagorda Fairways .....................................................................................12

DOE Geothermai Well Testing Program .....................................................................................13

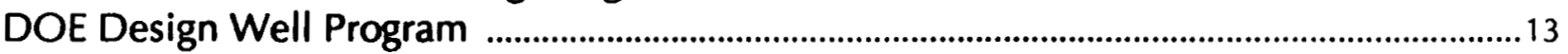

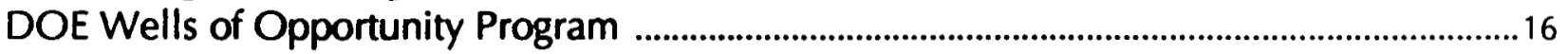

Summary of Geopressured-Geothermal Resources in Texas ..................................................17

Direct Use of Geothermal Fluids for

Improved Oil Recovery ..................................................................................................................18

Hot-Water Flooding .............................................................................................................18

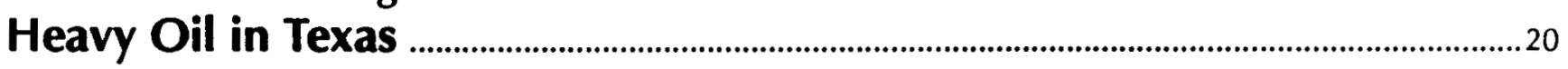

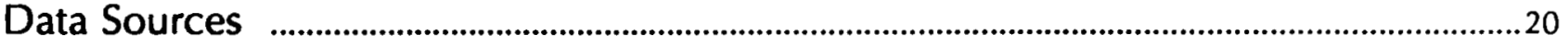

Texas Medium- and Heavy-Oil Plays ……………….................................................................2

Medium- and Heavy-Oil Reservoirs

in Jackson-Yegua Barrier/Strandplain Sandstones ...................................................................2.

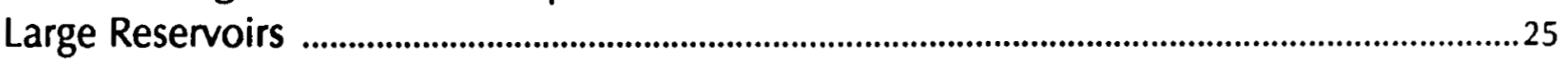

Heavy-Oil Reservoirs ....................................................................................................................29

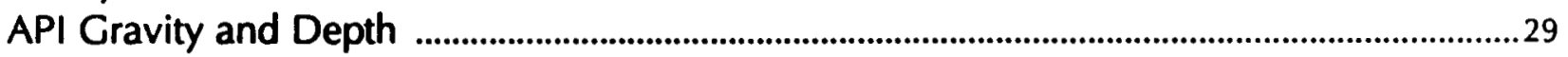

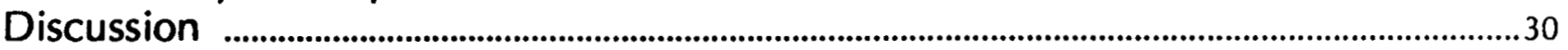

Jackson Group Sand-Body Geometry, Facies,

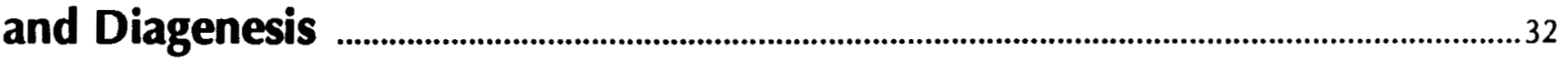

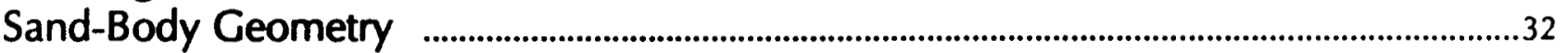

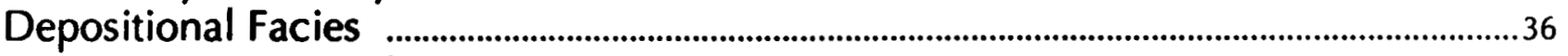

Reservoir Texture and Diagenesis .............................................................................................

Suitability of South Texas Heavy-Oil Reservoirs for

Thermally Enhanced Oil Recovery ..................................................................................41

Favorable Colocation Characteristics …………….............................................................42

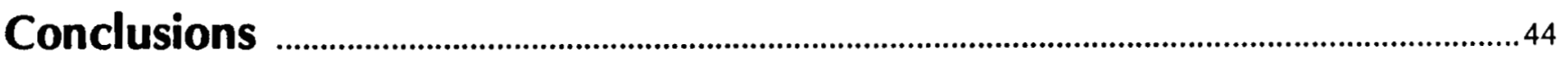




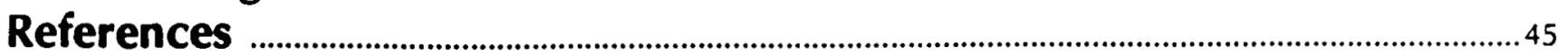

Appendix 1: Medium- and Heavy-Oil Reservoirs ......................................................49

Appendix 2: Wells on Cross Sections ...............................................................................50

Appendix 3: Abandoned Deep Gas Wells in South Texas .....................................51

\section{Figures}

1. Map of geothermal corridors

2. Flowchart illustrating a geothermally enhanced oil-recovery method ........................................................ 4

3. Schematic cross section of Cenozoic strata ............................................................................................6

4 Cenozoic formations and groups of Texas Gulf Coast ..........................................................................

5. Ceopressured-geothermal reservoir models $A$.

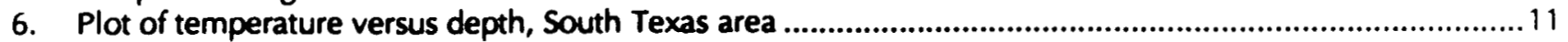

7. Location of geopressured-geothermal test well and structure of T5 marker ...........................................12

8. Location of geopressured-geothermal corridors and test wells ......................................................13

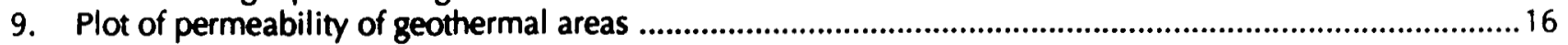

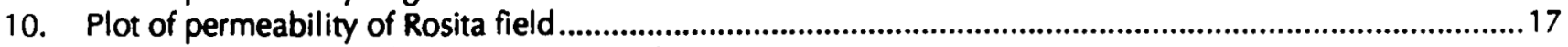

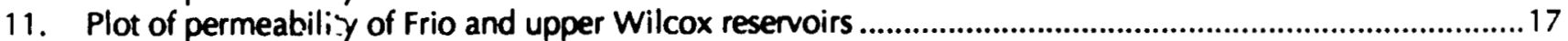

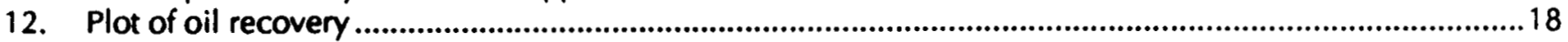

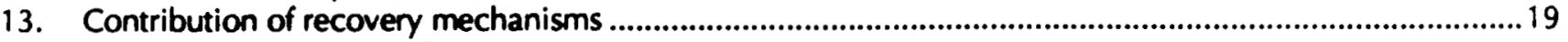

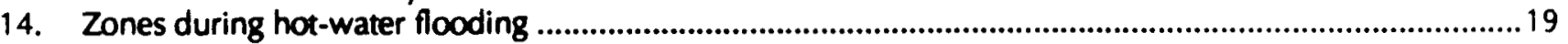

15. Map of Texas oil plays containing medium- and heavy-oil reservoirs .....................................................21

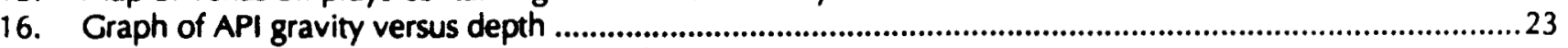

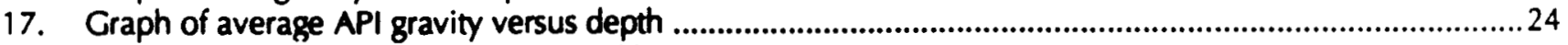

18. Geopressured-geothermal fairways and heavy-oil reservoirs ...................................................................25

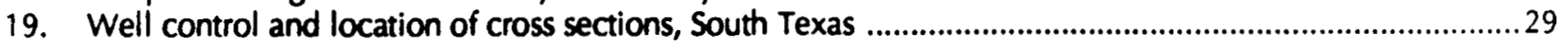

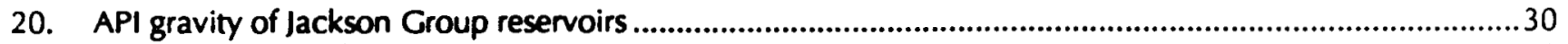

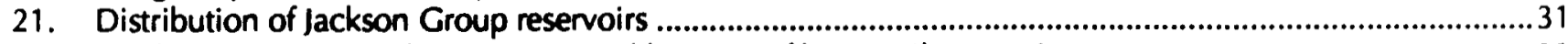

22. Sand-percent map, Jackson Group, and location of heavy-oil reservoirs..................................................33

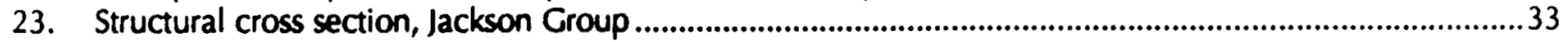

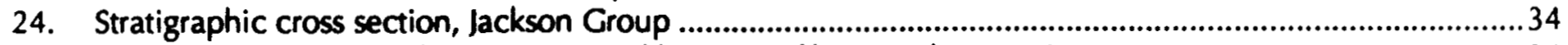

25. Net-sandstone map, Jackson Group, and location of heavy-oil reservoirs .................................................34

26. Net-sandstone map, Jackson Group, first Cole sand, and location of heavy-oil reservoirs ...........................35

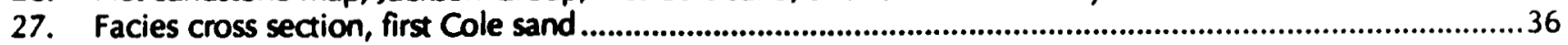

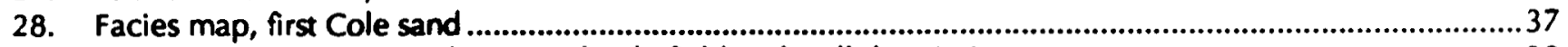

29. Structural cross section, Charco Redondo field and well description ..........................................................38

30. Well description, Texaco C-180-D, Charco Redondo field ............................................................................3.

31. Clay mineralogy, Texaco C-180-D, Charco Redondo field ......................................................................4

32. Core cross section, Charco Redondo field ................................................................................................40

33. Plot of porosity and permeability, first Cole sand .................................................................................40

34. Distribution of abandoned gas wells and heavy-oil reservoirs ..................................................................4 43

\section{Tables}

1. Characteristics of geopressured-geothermal reservoir models .................................................................10

2. Characteristics of geopressured-geothermal test wells ................................................................................14

3. Production statistics from large oil reservoirs in Texas ..............................................................................22

4. Comparative statistics of large heavy-, medium-, and light-oil reservoirs in Texas .................................23

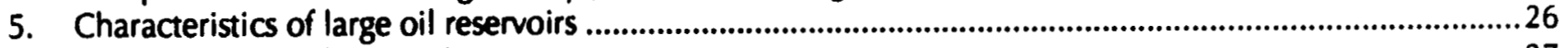

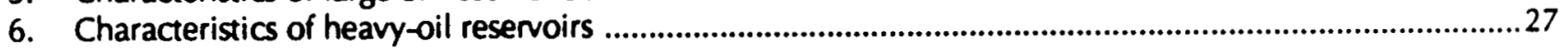




\section{Abstract}

In a five-county area of South Texas, geopressured-geothermal resenoirs in the Paleocene-Eocene Wilcox Group lie below medium- to heavy-oil reservoirs in the Eocene Jackson Group. This fortuitous association suggests the use of geothermal fluids for thermally enhanced oil recovery (TEOR). Ceothermal fainways are formed where thick deltaic sandstones are compartmentalized by growth faults. Wilcox geothermal reservoirs in South Texas are present at depths of 11,000 to $15,000 \mathrm{ft}(3,350$ to $4,570 \mathrm{~m})$ in laterally continuous sandstones 100 to $200 \mathrm{ft}(30$ to $60 \mathrm{~m}$ ) thick. Permeability is generally low (typically $1 \mathrm{md})$, porosity ranges from 12 to 24 percent, and temperature exceeds $250^{\circ} \mathrm{F}\left(121^{\circ} \mathrm{C}\right)$.

Reservoirs containing medium ( $20^{\circ}$ to $25^{\circ}$ API gravity) to heavy $\left(10^{\circ}\right.$ to $20^{\circ}$ API gravity) oil are concentrated along the Texas Coastal Plain in the Jackson-Yegua Barrier/Strandplain (Mirando Trend), Cap Rock, and Piercement Salt Dome plays and in the East Texas Basin in Woodbine Fluvial/Deltaic Strandplain and Paluxy Fault Line plays. The Jackson-Yegua Barrier/Strandplain (Mirando Trend) is the most favorable play for TEOR of medium to heavy oil because of the abundance of candidate reservoirs, relative simplicity of reservoir architecture, and shallow depth of burial. Updip pinch-out of shallow barrier bar/strandplain sandstones largely controls the distribution of medium- to heavy-ail reservoirs in the Jackson Group. Subtle structure, small faults, and sandstone-body pinch-outs form lateral barriers of the reservoirs. Structural, depositional, and diagenetic variations cause reservoir compartmentalization. The medium- to heavy-oil reservoirs are typically porous (25 to 35 percent) and permeable (100 to 1,000 mo), slightly clayey, fine- to medium-grained sand and sandstones. Calcite-cemented zones of low porosity (approximately 5 percent) and permeability (approximately $0.01 \mathrm{md}$ ) compartmentalize the reservoirs.

Injection of hot, moderately fresh to saline brines will improve oil recovery by lowering viscosity and decreasing residual oil saturation. Smectite clay matrix could swell and clog pore throats if injected waters have low salinity. The high temperature of injected fluids will collapse some of the interlayer clays, thus increasing porosity and permeability. Reservoir heterogeneity resulting from facies variation and diagenesis must be considered when siting production and injection wells within the heavy-oil reservoir. The ability of abandoned gas wells to produce sufficient volumes of hot water over the long term will also affect the economics of TEOR.

Keywords: geopressured-geothermal reservoirs, hot-water flood, Jackson Group, Mirando Trend, oil plays, South Texas, thermally enhanced oil recovery, Wilcox Group

\section{Introduction}

In Texas, geothermal resources are largely untapped despite their wide distribution. Three regions in the State that contain geothermal resources include the (1) geopressured-geothermal zone along the Texas Culf Coast, (2) rift-associated hydrothermal area of the Trans-Pecos, and (3) fault-associated hydrothermal area of Central Texas (fig. 1). Ceothermal resources could provide an auxiliary source of energy for diverse applications as well as a possible supply of potable water at some localities. Low-temperature hydrothermal resources associated with the Balcones and Mexia-Talco Fault Zones have experienced the most, albeit limited, development in Texas (Woodruff, 1982). Geopressured- geothermal resources along the Texas Gulf Coast have received the most study (for example, Meriwether, 1977; Bebout and Bachman, 1981; Dorfman and Morton, 1985; Negus-de Wys, 1990, 1991; Riggs and others, 1991) because they possess the highest temperatures and have associated natural gas. In the $1970^{\prime}$ s, early estimates indicated that vast energy resources associated with the geopressured-geothermal fluids might be able to generate electricity and produce natural gas (Jones, 1976; Wallace and others, 1979). Subsequent resource estimates using data gathered from geopressured-geothermal research programs drastically shrank the earlier overly optimistic estimates of the size of the resource base 


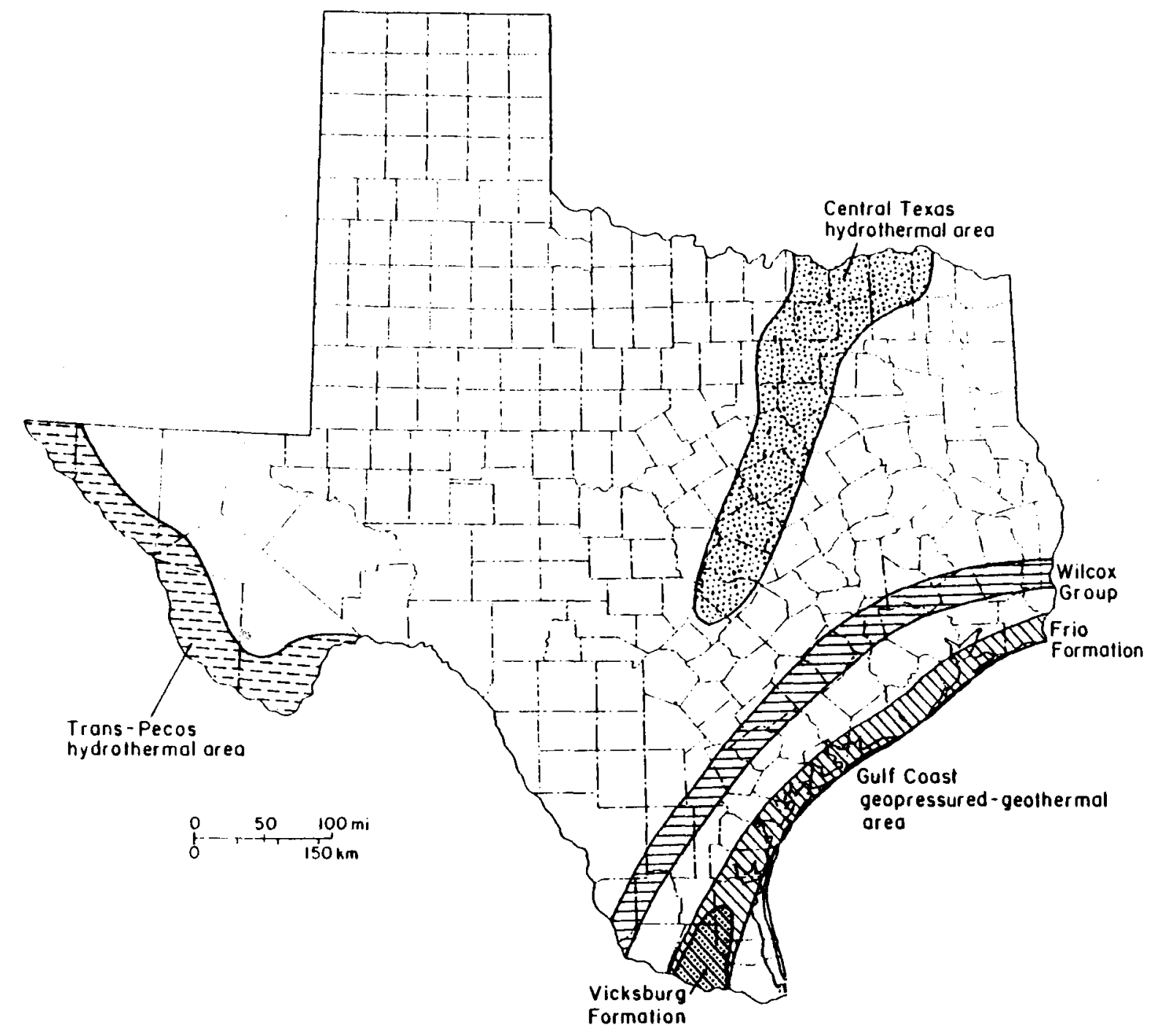

Figure 1. Map outlining areas containing geothermal resources in Texas and geopressured-geothermal corridors along Texas Gulf Coast (Bebout and others, 1978, 1982; Gregory and others, 1980; Woodruff, 1982).

(Gregory and others, 1980). Declines in the price of oil and gas also had a negative impact on the economics of geothermal resource utilization (Wrighton, 1981). Without price or tax incentives, the generation of electricity through production of geopressured-geothermal energy is unlikely to be economical, given the current price (1990-1992) for competitive energy sources such as oil $(\$ 20$ to $\$ 25 / \mathrm{bbl}$ ) and gas ( $\$ 1.50$ to $\$ 2.00 / \mathrm{Mct}$ ).

Ceothermal waters in Texas range in temperature from less than $100^{\circ} \mathrm{F}$ to greater than $350^{\circ} \mathrm{F}\left(<38^{\circ} \mathrm{C}\right.$ to $\left.>177^{\circ} \mathrm{C}\right)$ but are not hot enough to directly generate electricity using steam-driven turbines. These geothermal resources may be suitable for binary-cycle conversion, in which the geothermal fluids vaporize a working fluid (freon, isobutane, or isopentane), which would then drive a turbine generator. The technology for commercial use of moderate-temperature geothermal fluids to generate electricity has been proven in California and has also been successfully tested in a geopressured-geothermal well in Texas.

Generating electricity efficiently from geopressuredgeothermal resources requires using all of the multiple components of the resource, such as thermal energy (hot water), chemical energy (dissolved natural gas), and kinetic energy (hydraulic power), each of which is uneconomical to exploit individually. The large initial 
investment inhibits developing geothermal resources that are a relatively low unit value commodity. In Texas, the commercial success of such a procedure is currently hampered by uncertainties about the size and productivity of individual geothermal reservoirs, low prices for natural gas, flat demand for electricity, higher rate of return from competing energy resources such as oil and gas, high costs of drilling and completing geothermal wells, high costs of customized plant design and fabrication, and high costs of disposal of spent fluids. Geothermal fluid must also be produced cheaply and in large quantities to be economically feasible. The economics are especially sensitive to the flow rate and productive life of individual wells, which are best determined on the basis of long-term flow tests. Many variables can affect well productivity and flow rates, and reservoir performance must be individually determined for each well. However, the direct use of geopressured-geothermal fluids for applications that require varying temperatures is the most likely way the energy will be used in the near term (Lunis and others, 1991).

\section{Direct Use of Geothermal Resources}

Direct uses include space heating or other industrial processes that require moderate temperatures, such as agriculture, aquaculture, or thermally enhanced oil recovery (TEOR). First proposed by Negus-de Wys (1989), recovery of heavy oil by injecting geopressuredgeothermal fluids for hot-water flooding is one directuse method with particularly attractive economic incentives (Negus-de Wys and others, 1991). Heavy-oil reservoirs are characterized by poor recovery efficiencies because the oil is highly viscous and resists extraction. Enhanced recovery strategies that apply geothermal energies to reduce viscosity in medium- to heavy-oil reservoirs have the potential to improve recovery efficiency, resource conservation (heat would not be generated by combustion), and environmental protection (no release of greenhouse gases). Because of the difficulty of conserving the heat energy during long-distance transport (Hannah, 1975), geothermal resources must be located close to heavy-oil reservoirs.

In the Gulf Coast region, geothermal and heavy-oil resources are located together in South Texas where a geothermal fairway in the Paleocene-Eocene Wilcox Group lies 2 to $3 \mathrm{mi} \mathrm{(} 3$ to $5 \mathrm{~km}$ ) below a trend of heayoil reservoirs in the shallow Eocene Jackson Group. Geothermal fluids produced from the deeply buried Tertiary geopressured-geothermal reservoirs could be injected into shallow oil reservoirs to supply both the heat energy and fluid for enhanced oil recovery by steam or hot-water flooding (fig. 2). Although the incremental gain in production from injecting hot water is substantial compared with that gained from injecting cold water during a typical waterflood, such improvements are less significant than those resulting from injecting steam (Burger and others, 1985). A TEOR process would result in energy savings and resource conservation by maximizing the percentage of oil recovered from the reservoir and by eliminating the standard practice of heating the injection fluids through combustion of hydrocarbons. In situations where steam injection is impractical or uneconomical, injection of geothermally heated water may offer an economically attractive alternative. Although Negus-de Wys and others (1991) suggested that TEOR geopressured-geothermal fluids could be economically viable in South Texas because of the colocation of geothermal resources below heavy-oil reservoirs and because of the size of the heavy-oil and geothermal resources, the geothermal-well productivity and dissolved gas content may have been overestimated.

\section{Objectives}

This report characterizes geothermal resources and medium- to heavy-oil reservoirs in Texas, with emphasis on the South Texas area where geothermal and mediumto heavy-oil reservoirs are colocated. Specifically, we consider the feasibility of using geothermal brines to supply heat and fluids for a TEOR program to increase production from medium- to heavy-oil reservoirs. The report is organized in five sections that (1) provide background information on types of geothermal resources and review geologic and engineering characteristics of the geopressured-geothermal resources in Texas, (2) examine the use of geothermal fluids for TEOR, (3) characterize medium- to heavy-oil reservoirs and plays in Texas, (4) characterize medium- to heavyoil reservoirs in the Mirando Trend in South Texas, and (5) discuss suitability of medium- and heavy-oil reservoirs in South Texas for geothermally sourced TEOR. We focus on characterizing aspects of heavy-oil reservoirs that would affect use of geopressured-geothermal fluids in a TEOR program. The study area includes five counties in South Texas (Duval, Jim Hogg, Starr, Webb, and Zapata Counties) where known geothermal fairways in the deep Wilcox Group (Gregory and others, 1980; Bebout and others, 1982) are favorably located below the shallow Mirando Trend of medium- to heavy-oil reservoirs (Galloway and others, 1983; Hamlin and others, 1989; Seni and Walter, 1990; Negus-de Wys and others, 1991). 
Fandango field

Shell No. 2 Leyendecker
Alworth field

Price No. 5 Garza

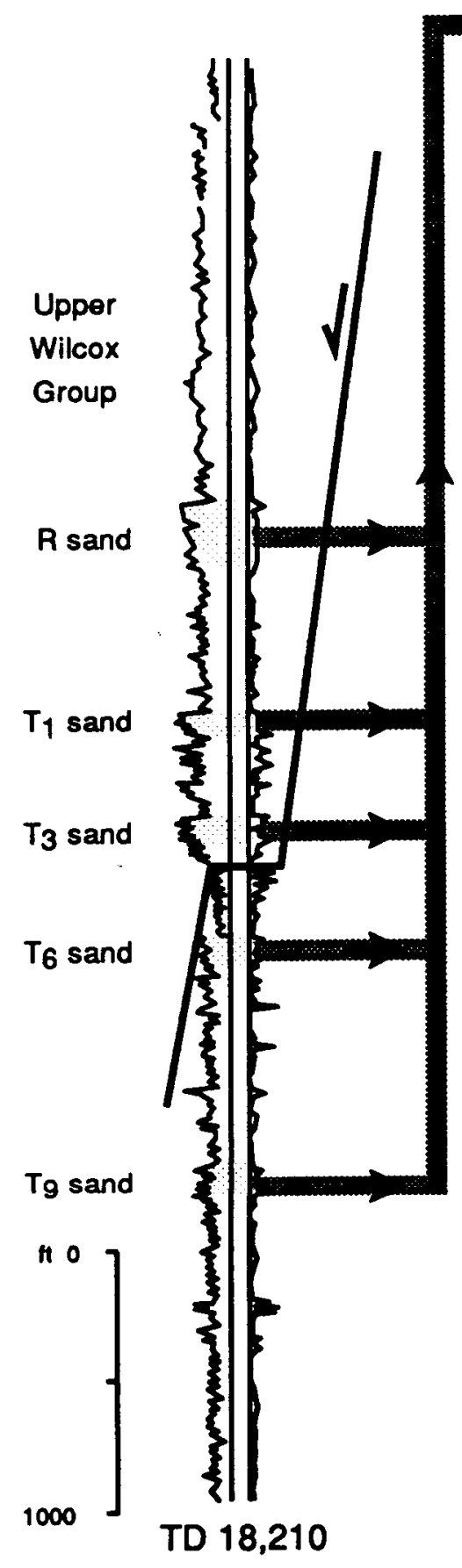

Hot-water production well

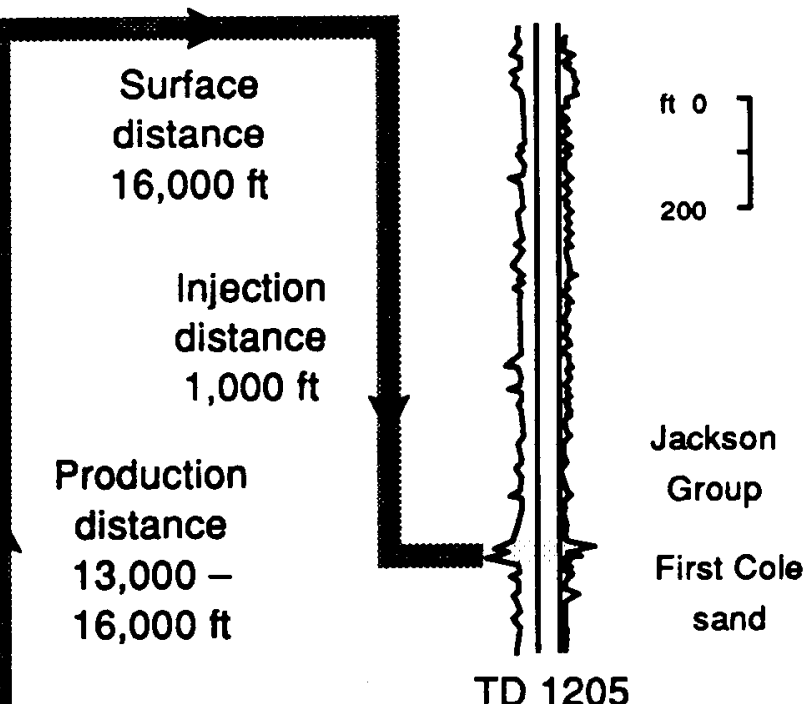

TD 1205

Injection well

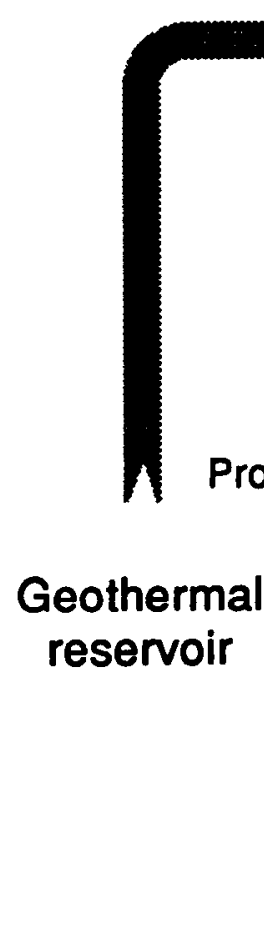

Production

Heavy-oil

reservoir

Injection

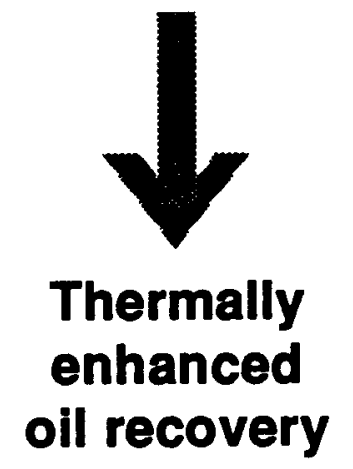

QA

$14767 c$

Figure 2. Schematic flow chart illustrating a geothermally enhanced oil recovery method utilizing geothermal water from reservoirs in the Wilcox to inject into shallow heavy-oil reservoirs in the Jackson Group. 


\section{Geothermal Resources in Texas}

\section{Types of Geothermal Resources}

Geothermal resources can be divided into categories on the basis of the nature and origin of the resource: hydrothermal, petrothermal (hot-dry rocks), and geopressured-geothermal. The heat energy for the first two categories is generally supplied by a large body of hot rock, or magma. In a hydrothermal system, ground water becomes heated or vaporized after contacting surrounding hot rock. Such resources are considered renewable if ground water is replenished by seasonal rainfall or snowmelt. In petrothermal systems, the energy content of hot rocks is abundant but not inexhaustible. The phase of the geathermal fluid is dependent on depth and pressure and may include hot water, steam, or a mixture of the two. The Geysers, California, is an example of a vapor-dominated system that provides electrical power at a relatively low cost because the single steam phase contains no liquids that need to be separated (Barker and others, 1991).

In geopressured-geothermal systems, water trapped within a subsurface sandstone reservoir is heated by pressure and surrounding hot strata during rapid, deep burial of sediments within young sedimentary basins (Dorfman and Kehle, 1974; Bebout and others, 1978). The depositional and structural style of the Cenozoic strata along the Texas Gulf Coast favored the accumulation of thick lenses of permeable sandstone that became hydrologically isolated during burial (fig. 3). The geopressured-geothermal reservoir is sealed by relatively impermeable shale and faults. Insulating layers of thick shales encase the reservoir sandstones and retain heat within the geopressured resenoirs. The high temperature of the geopressured fluids is a result of the normal increase in temperature during burial and convective transport of heat by fluid flow. The typical geothermal gradient in the Gulf of Mexico region is $1.6^{\circ} \mathrm{F} / 100 \mathrm{ft}\left(25^{\circ} \mathrm{C} \mathrm{km}^{-1}\right)$ (Bodner and others, 1985). Regionally, temperatures and geothermal gradients in the subsurface generally decrease from as high as $2.7^{\circ} \mathrm{F} / 100 \mathrm{ft}\left(42^{\circ} \mathrm{C} \mathrm{km}^{-1}\right)$ along the inner coastal plain to $1.1^{\circ} \mathrm{F} / 100 \mathrm{ft}\left(17^{\circ} \mathrm{C} \mathrm{km}^{-1}\right)$ offshore. In addition, gradients are higher toward the southwest, increasing by as much as $0.53^{\circ} \mathrm{F} / 100 \mathrm{ft}\left(8^{\circ} \mathrm{C} \mathrm{km}^{-1}\right)$ across South Texas (Bodner and others, 1985). Abrupt increases in temperature gradients at depth commonly correspond to overpressuring (Lewis and Rose, 1970), particularly near growth faults. Gradients then decrease to nearly normal levels at greater depths.
The fluids become overpressured by partially supporting the weight of the overlying column of rock during continued burial. In a normally pressured area, fluid pressure increases with increasing depth as a function of the weight of the overlying column of water. This normally pressured area is referred to as the hydrostatic zone. In the Gulf Coast region, formation fluids are considered geopressured when fluid pressure gradients exceed $0.465 \mathrm{psi} / \mathrm{ft}\left(10.5 \mathrm{kPa} \mathrm{m}^{-1}\right)$ (Bebout and others, 1982). Limited fluid circulation within the overpressured interval causes the pressure gradient to rise from 0.7 to $1.0 \mathrm{psi} / f \mathrm{t}$ (15.8 to $22.6 \mathrm{kPa} \mathrm{m}^{-1}$ ). Ceothermal fairways are typically characterized by temperatures greater than $300^{\circ} \mathrm{F}\left(>149^{\circ} \mathrm{C}\right)$, fluid pressures above $0.7 \mathrm{psi} / \mathrm{tt}$ $\left(>15.8 \mathrm{kPa} \mathrm{m}^{-1}\right)$, and sandstone thicknesses exceeding $300 \mathrm{ft}(>91 \mathrm{~m})$. Because geopressured-geothermal fluids are sealed within deep reservoir strata, they should be considered nonrenewable resources similar to oil and gas. Although geopressured-geothermal resources are best known in the northern Gulf of Mexico basin, geopressured basins are common in the United States and worldwide (Fertl and others, 1976).

\section{Geopressured- Geothermal Resources: Previous Research}

The Bureau of Economic Geology and the Center for Geosystems Engineering of The University of Texas at Austin have participated in a long-term research program funded by the U.S. Department of Energy (DOE) to evaluate geopressured-geothermal resources in Texas (Dorfman and Deller, 1975, 1976; Podio and others, 1976; Bebout and others, 1978, 1982; Dorfman and Fisher, 1979; Gregory and others, 1980; Bebout and Báchman, 1981; Dodge and Posey, 1981; Morton and others, 1983; Dorfman and Morton, 1985; Riggs and others, 1991). Similar programs have been funded by DOE to evaluate geopressured-geothermal reservoirs in Louisiana (Bebout and Gutierrez, 1981; McCulloh and Pino, 1981; Snyder and Pilger, 1981). As a result of this research program, a substantial body of information is now available concerning the location, distribution, and productivity of the resource. The initial research task was to assess the potential for electrical generation from the deep subsurface brines in onshore Tertiary strata. Primary goals were to locate prospective reservoirs that met the following specifications: fluid temperatures of 


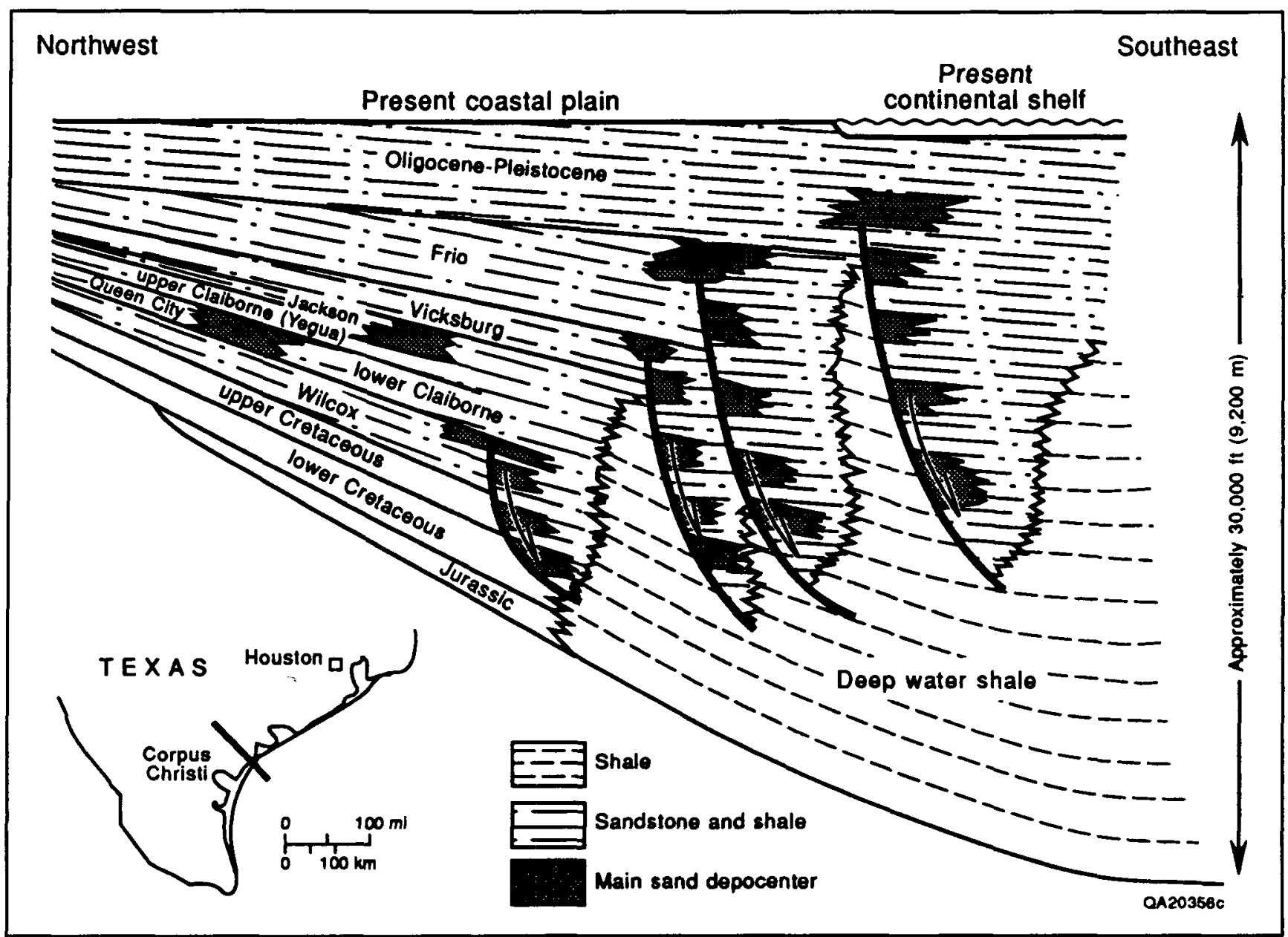

Figure 3. Schematic model of depositional and structural style of Cenozoic strata along Texas Culf Coast (after Bebout and others, 1982).

$300^{\circ} \mathrm{F}\left(149^{\circ} \mathrm{C}\right)$ or higher, pressure gradients higher than $0.7 \mathrm{psi} / \mathrm{ft}\left(>15.8 \mathrm{kPa} \mathrm{m}^{-1}\right)$, a reservoir volume of $3 \mathrm{mi}^{3}\left(12.5 \mathrm{~km}^{3}\right)$, and minimum permeability of $20 \mathrm{md}$ $\left(0.02{\mu \mathrm{m}^{2}}^{2}\right.$ (Bebout and others, 1978; Monton, 1981). The recognition that geothermal brine contained substantial dissolved natural gas focused research on quantifying the gas component. Early, optimistic projections (Jones, 1976) suggested that brines contained as much as 40 to $120 \mathrm{sct} / \mathrm{bbl}\left(7.2\right.$ to $21.6 \mathrm{~m}^{3} \mathrm{gas} \mathrm{m}-3$ brine). However, gas solubility was found to be a function of the salinity of the brine; high salinities reduced gas solubility (Blount and others, 1979; Gregory and others, 1980). Long-term well tests of geothermal wells indicated that gas content of the brines ranged from 20 to $34 \mathrm{sct} / \mathrm{bbl}$ (3.6 to $6.1 \mathrm{~m}^{3}$ gas m-3 brine) (Negus-de Wys and others, 1991). More detailed information on regional-assessment and site-selection studies of Tertiary formations in the Texas Culf Coast has concentrated on the Frio, Vicksburg, and Wilcox strata (Bebout and others, 1975a, b, 1976, 1978, 1982;
Loucks, 1979; Gregory and others, 1980; Edwards, 1981; Morton and others, 1983; Winker and others, 1983).

\section{Geothermal Corridors}

Broad geopressured-geothermal corridors within Tertiary formations in the Gulf Coast of Texas (figs. 1 and 4) contain localized geothermal fairways or prospects that are characterized by the coexistence of high subsurface fluid temperatures $\left(>250^{\circ} \mathrm{F}\left[>121^{\circ} \mathrm{C}\right]\right.$ ) and thick permeable sandstones. Ceopressured-geothermal aquifers develop when thick sandstone bodies are hydrologically isolated by subsidence and rapid burial within fault blocks (Winker and others, 1983). Thick sandstone bodies provide the necessary large reservoirs for the geothermal fluids. In the Gulf Coast Basin, such corridors typically are present where deltaic, shoreline, and shelf-margin sandstones accumulated syndepositionally on the downthrown side of regional growth faults 


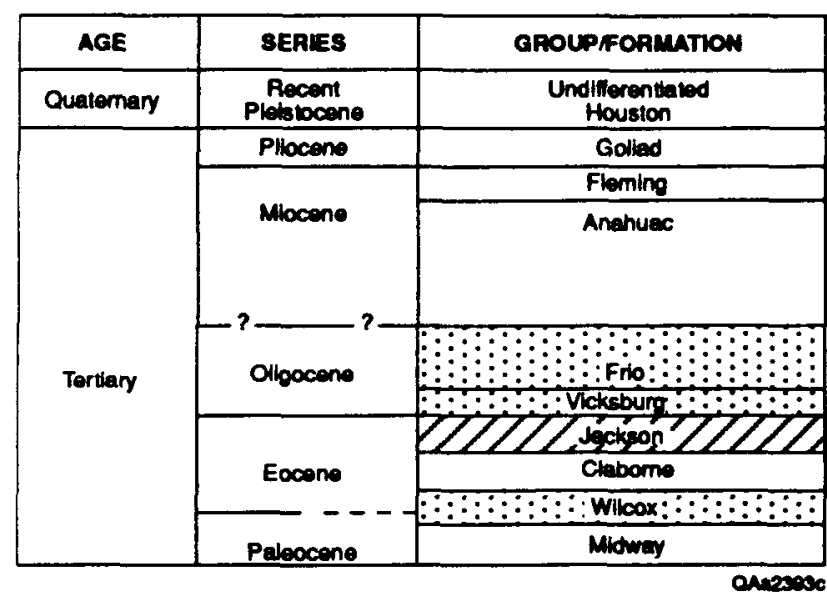

Figure 4. Stratigraphic chart of Texas Gulf Coast Cenozoic formations and groups. Ceopresured-geothemal units are in stippled pattem (Bebout and others, 1978). Mediumand heavy-oil reservoirs are most common in Jackoon Group (lined pattern).

(fig. 3). Belts of growth faults were formed by large-scale basinward sliding of the unstable shelf edge and by salt and shale tectonics (Ewing, 1986). In addition to determining the thickness of reservoir sandstones and the temperatures of geothermal fluids, examining permeability is necessary to characterize first-order geothermal prospectivity (Bebout and others, 1978).

Around the northern and western arc of the Gulf of Mexico depositional basin, reservoirs of geopressuredgeothermal fluids lie in major sandstone-rich Tertiary sequences, including: (1) the Paleocene-Eocene Wilcox Group, (2) the Eocene Yegua Formation, (3) the Oligocene Vicksburg Group, (4) the Oligocene Frio Formation, and (5) Miocene formations. Yegua and Vicksburg strata contain geothermal resources that are less favorable for production because reservoir sandstones at suitable depths are laterally restricted or have low permeability (Loucks, 1979). In Texas, Miocene strata have not been buried to sufficient depth to host favorable geothermal resources. In Louisiana, however, Miocene strata have been buried more deeply, and a DOE geothermal design well-Gladys McCall No. 1 - has been completed in Miocene strata (Clark, 1985; Durrett, 1985; Prichett and Riney, 1985). Both the Wilcox and Frio depositional units in Texas contain the thick, sandstonerich corridors at the appropriate depth and structural setting to produce geothermal fluids (Bebout and others, 1978, 1982). Within these broad corridors are smaller geothermal fairways or prospects that contain thick potential reservoir sandstones with elevated reservoir temperatures and pressures.

\section{Wilcox Geothermal Fairways}

The Wilcox Group, together with the underlying Midway Group, constitutes the oldest thick sandstone/ shale wedge within the Gulf Coast Tertiary System. The faulted downdip section of the Wilcox Group constitutes the Wilcox geothermal corridor. Sediments within the updip part of the Wilcox wedge were deposited primarily by fluvial systems. Large delta systems deposited thick, sandstone-rich sequences in the lower and upper Wilcox (Edwards, 1981; Bebout and others, 1982). Marine processes reworked some deltaic sediments and redistributed sediments alongshore in barrier bar/strandplain environments. Growth faults developed between the shoreline and shelf margin of the larger delta lobes, where thick deposits of sand and mud accumulated over unconsolidated offshore mud of the underlying sediment wedge. Subsidence along these faults isolated thick sandstone sequences, which prevented escape of pore fluids during burial.

Six geothermal fairways are identified within the corridor on the basis of sandstone distribution and reservoir temperature (fig. 5). The geology of these six geothermal fairways is represented by two Wilcox reservoir models (Bebout and others, 1982; Gregory and others, 1980). Table 1 summarizes characteristics of the resenoir models.

\section{Model I-South Texas upper Wilcox Fairways}

Model I represents upper Wilcox geopressuredgeothermal reservoirs in South Texas. High-constructive lobate deltas of the upper Wilcox are growth faulted along the lower Wilcox shelf margin, forming vertically stacked reservoirs of delta-front sandstones (Edwards, 1981). Zapata, Duval, and Live Oak Fairways represent major sand depocenters associated with three deltalobe complexes. In the Zapata Fainway, more than $1,500 \mathrm{ft}(>457 \mathrm{~m})$ of net sandstone accumulated in growth-faulted compartments (Seni and Walter, 1990). The maximum thickness of individual sandstone bodies is as much as $200 \mathrm{ft}(61 \mathrm{~m})$. To the north, in the Duval and Live Oak Fairways, individual sandstone bodies are thinner, and net sandstone packages are 300 to $700 \mathrm{ft}$ (91 to $213 \mathrm{~m}$ ) thick. Reservoir temperatures are moderate to high $\left(250^{\circ}\right.$ to $471^{\circ} \mathrm{F}\left[121^{\circ}\right.$ to $\left.\left.244^{\circ} \mathrm{C}\right]\right)$ as a result of high geothermal gradients and substantial reservoir depth (fig. 6). Reservoir sandstones in the upper Wilcox are relatively continuous along strike, but numerous growth faults restrict continuity in a dip direction. Average porosity in model I fairways, which ranges from 17 to 22 percent, is favorable, but permeability is the restraint on geothermal reservoir potential in the upper 


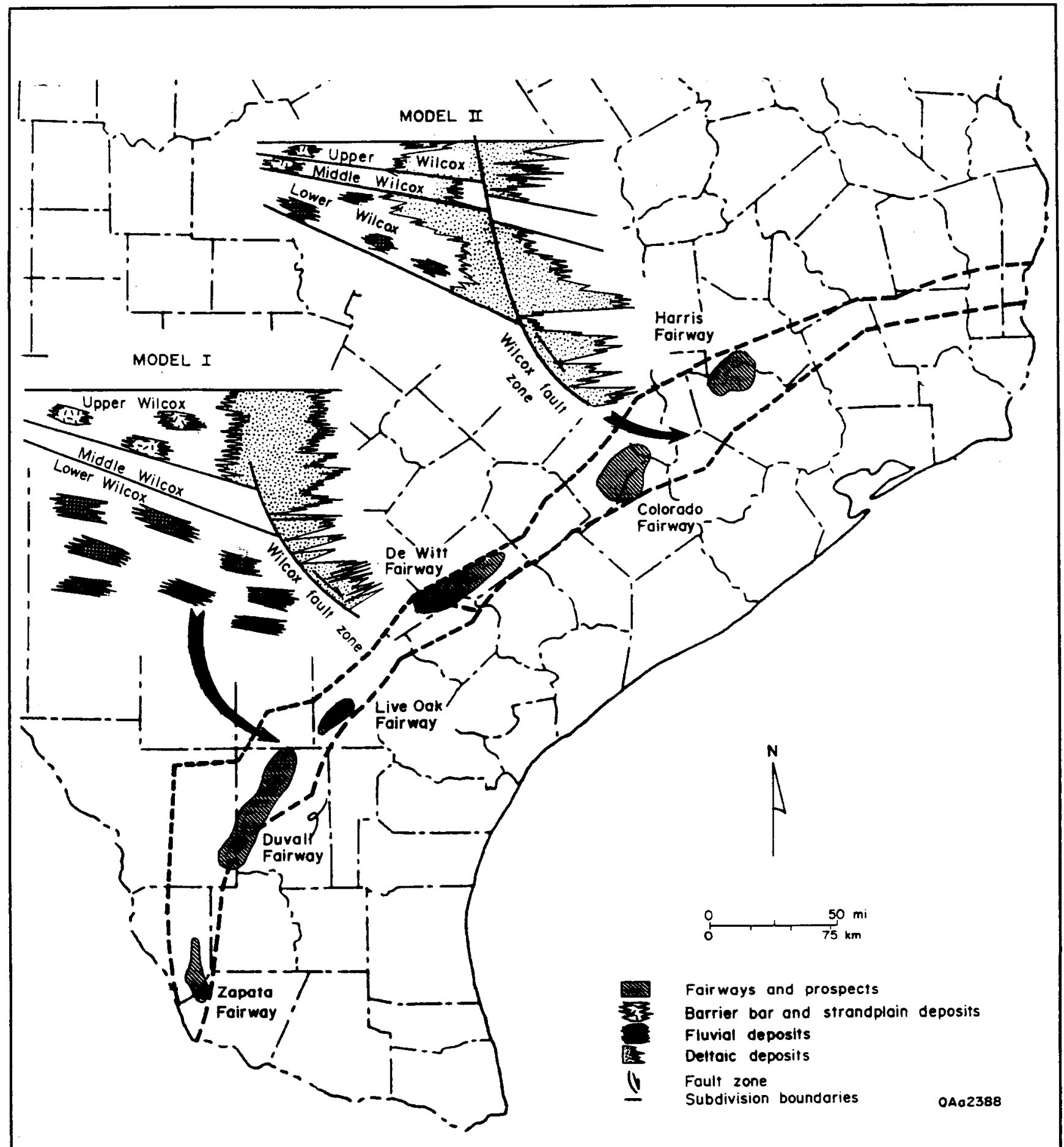

(a)

Figure 5. (a) Wilcox geopressured-geothermal reservoir models I and II and geopressured-geothermal corridor and fairways (Gregory and others, 1980; Bebout and other3, 1982). (b) Frio geopressured-geothermal reservoir models II, IV, and $V$ and geopressured-geothermal corridor, fairways, and prospects (Bebout and others, 1978; Gregory and others, 1980). 





Table 1. Characteristics of geopressured-geothermal reservoir models.*

\begin{tabular}{|c|c|c|c|c|c|c|c|}
\hline Model & Sand geometry & Temperature & Pressure & Salinity & $\begin{array}{l}\text { Methane } \\
\text { solubility }\end{array}$ & $\begin{array}{l}\text { Porosity and } \\
\text { permeability }\end{array}$ & $\begin{array}{l}\text { Factors limiting } \\
\text { reservoir potential }\end{array}$ \\
\hline \multicolumn{8}{|l|}{ Model I } \\
\hline Upper Wilcox & $\begin{array}{l}\text { Thick, laterally extensive } \\
\text { sands }\end{array}$ & $\begin{array}{l}\text { Moderate to } \\
\text { high }\end{array}$ & $\begin{array}{l}\text { Moderate to } \\
\text { high }\end{array}$ & $\begin{array}{l}\text { Low to } \\
\text { moderate }\end{array}$ & $\begin{array}{l}\text { Low to } \\
\text { moderate }\end{array}$ & Low & $\begin{array}{l}\text { Low to moderate methane } \\
\text { solubility, low porosity and } \\
\text { permeability }\end{array}$ \\
\hline Lower Wilcox & $\begin{array}{l}\text { Thin, areally extensive } \\
\text { sands }\end{array}$ & High & High & Low & High & Very low & $\begin{array}{l}\text { Thin sands, very low porosity } \\
\text { and permeability }\end{array}$ \\
\hline \multicolumn{8}{|l|}{ Model II } \\
\hline Upper Wilcox & $\begin{array}{l}\text { Moderately thick sands, } \\
\text { moderately continuous }\end{array}$ & $\begin{array}{l}\text { Low to } \\
\text { moderate }\end{array}$ & $\begin{array}{l}\text { Low to } \\
\text { moderate }\end{array}$ & Low to high & $\begin{array}{l}\text { Low to } \\
\text { moderate }\end{array}$ & Low & $\begin{array}{l}\text { Low porosity and permeability, } \\
\text { low pressure in updip areas }\end{array}$ \\
\hline Lower Wiloox & $\begin{array}{l}\text { Thick, laterally extensive } \\
\text { sands }\end{array}$ & High & High & High & High & $\begin{array}{l}\text { Low, locally high } \\
\text { in De Witt Fairway }\end{array}$ & Low porosity and permeability \\
\hline \multicolumn{8}{|l|}{ Model III } \\
\hline Upper Frio & Thick, areally limited sands & $\begin{array}{l}\text { Moderate to } \\
\text { high }\end{array}$ & $\begin{array}{l}\text { Moderate to } \\
\text { high }\end{array}$ & $\begin{array}{l}\text { Low to } \\
\text { moderate }\end{array}$ & High & Low & $\begin{array}{l}\text { Areally limited sands, low } \\
\text { porosity and permeability }\end{array}$ \\
\hline Lower Frio & $\begin{array}{l}\text { Thin, basal sands, laterally } \\
\text { continuous }\end{array}$ & Very high & Very high & $\begin{array}{l}\text { Low to } \\
\text { moderate }\end{array}$ & High & Very low & Low porosity and permeability \\
\hline Vicksburg & Thick, areally limited sands & High & High & $\begin{array}{l}\text { Low to } \\
\text { moderate }\end{array}$ & High & Very low & $\begin{array}{l}\text { Areally limited sands, low } \\
\text { porosity and permeability }\end{array}$ \\
\hline \multicolumn{8}{|l|}{ Model IV } \\
\hline Upper Frio & $\begin{array}{l}\text { Thick, areally extensive } \\
\text { sands }\end{array}$ & Low & Low & High & $\begin{array}{l}\text { Low to } \\
\text { moderate }\end{array}$ & High & $\begin{array}{l}\text { Low to moderate methane } \\
\text { solubility, low pressure }\end{array}$ \\
\hline Lower Frio & Thin, areally limited sands & $\begin{array}{l}\text { Moderate to } \\
\text { high }\end{array}$ & $\begin{array}{l}\text { Moderate to } \\
\text { high }\end{array}$ & Low & $\begin{array}{l}\text { Moderate to } \\
\text { high }\end{array}$ & Low & $\begin{array}{l}\text { Areally limited sands, low } \\
\text { porosity and permeability }\end{array}$ \\
\hline \multicolumn{8}{|l|}{ Model V } \\
\hline Upper Frio & $\begin{array}{l}\text { Thin to moderately thick } \\
\text { sands, areal extent variable }\end{array}$ & $\begin{array}{l}\text { Low to } \\
\text { moderate }\end{array}$ & $\begin{array}{l}\text { Low to } \\
\text { moderate }\end{array}$ & $\begin{array}{l}\text { Moderate to } \\
\text { high }\end{array}$ & $\begin{array}{l}\text { Low to } \\
\text { moderate }\end{array}$ & High & $\begin{array}{l}\text { Low to moderate methane } \\
\text { solubility and pressure, low total } \\
\text { sand volume }\end{array}$ \\
\hline $\begin{array}{l}\text { Matagorda } \\
\text { Fainway }\end{array}$ & Thin, areally limited sands & High & $\begin{array}{l}\text { Moderate to } \\
\text { high }\end{array}$ & High & $\begin{array}{l}\text { Moderate to } \\
\text { high }\end{array}$ & High & Thin, areally limited sands \\
\hline Brazoria Fainway & $\begin{array}{l}\text { Thick, areally extensive } \\
\text { sands }\end{array}$ & High & $\begin{array}{l}\text { Moderate to } \\
\text { high }\end{array}$ & High & $\begin{array}{l}\text { Moderate to } \\
\text { high }\end{array}$ & High & Thin, areally limited sands \\
\hline
\end{tabular}




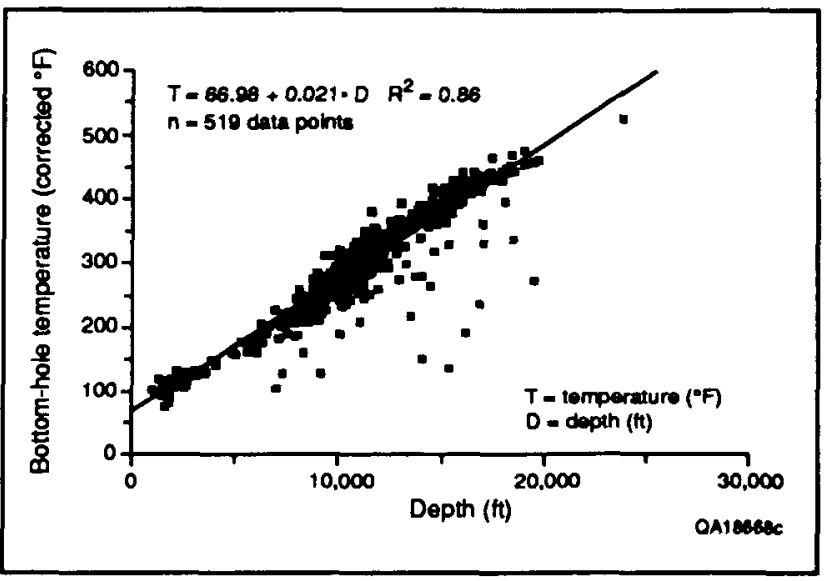

Figure 6. Plot of temperature as a function of depth for deep upper Wilcox wells in South Texas. Well log bottomhole temperature corrected to equilibrium temperature after the method of Kehle (1971).

Wilcox. At depths where geothermal reservoirs are developed, average permeabilities are very low, ranging

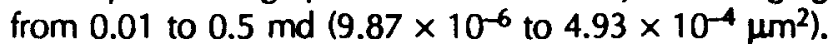
Core analysis indicates that low porosities and permeabilities will limit production from potential geopressuredgeothermal reservoirs (Bebout and others, 1982).

\section{Model II- Lower Wilcox De Witt, Colorado, and Harris Fairways}

Model II represents potential geothermal reservoirs in the lower Wilcox along the middle and upper Texas Coastal Plain (Gregory and others, 1980; Bebout and others, 1982). The sandstone geometry and structure in De Witt, Colorado, and Harris Fairways are characteristic of this model. High-constructive, lobate lower Wilcox deltas were extensively growth faulted when they prograded across the underlying Cretaceous carbonateshelf margin. Delta-front sheet sands accumulated to great thicknesses across growth-fault zones. Reservoir size is limited by restricted dip extent and lateral facies changes. In the De Witt Fairway, from 400 to $1,000 \mathrm{ft}$ $(121$ to $305 \mathrm{~m})$ of net sandstone accumulated. A maximum net sandstone thickness of 1,200 to $1,600 \mathrm{ft}$ $(366$ to $488 \mathrm{~m})$ is found in the lower Wilcox in the Colorado Fairway. Maximum net sandstone thickness is more than 2,000 ff $(>610 \mathrm{~m})$ in the Harris Fainway. Available core data show that most permeabilities of model II sandstones in the deep subsurface are less than $1 \mathrm{md}\left(<9.87 \times 10^{-4} \mu \mathrm{m}^{2}\right)$. Locally, permeabilities are highest in the De Witt Fainway, where permeabilities range from less than 2.1 to greater than $100 \mathrm{md}$ $\left(<2.07 \times 10^{-3} \mu \mathrm{m}^{2}\right.$ to $\left.>9.87 \times 10^{-2} \mu \mathrm{m}^{2}\right)$. The highest permeability is typically at the top of sandstone-bearing intervals in thick channel-fill sandstones.

\section{Frio Geothermal Fairways}

Five geothermal fairways and three prospects that lie within the Frio geothermal corridor along the Coastal Zone of Texas were simplified into three reservoir models (Bebout and others, 1978; Gregory and others, 1980) (fig. 5b). The geothermal fairways are present where contemporaneous growth faults promoted the accumulation of thick deposits of sandstone at a depth currently characterized by high subsurface temperature and pressure. A substantial body of data had been previously collected for geothermal resources in the Frio Formation in Texas (Bebout and others, 1975a, b, 1976, 1978). Reservoir-specific information relevant to the production of geothermal energy in the Frio formation of Texas has been evaluated in one DOE design well (Morton, 1981; Morton and others, 1983; Winker and others, 1983).

\section{Model III- Hidalgo and Armstrong Fairways}

The Hidalgo and Armstrong Fairways in South Texas contain geothermal waters having temperatures from $250^{\circ}$ to more than $300^{\circ} \mathrm{F}\left(121^{\circ}\right.$ to $\left.>149^{\circ} \mathrm{C}\right)$. Fluid temperatures in the Armstrong Fainway are relatively low. Thick, extensive sandstones characterize both fairways. Total net sandstone of more than $300 \mathrm{ft}(>91 \mathrm{~m})$ extends over an area of $50 \mathrm{mi}^{2}\left(129 \mathrm{~km}^{2}\right)$ in the Armstrong Fairway. Numerous thick sandstone reservoirs of adequate size are present at depths greater than $13,000 \mathrm{ft}(>3,962 \mathrm{~m})$ in the Hidalgo Fairway. However, both fairways are limited by extremely low permeabilities. Near the Frio Hildago Fainway, a favorable resource fairway was mapped in the underlying Vicksburg Formation that is also characterized by low permeabilities (Loucks, 1979). Swanson and others (1976), analyzing fields producing from the geothermal zone, found that most sandstone permeabilities are less than or equal to $1 \mathrm{md}\left(\mathrm{s} 9.87 \times 10^{-4} \mu \mathrm{m}^{2}\right)$.

\section{Model IV-Corpus Christi Fairway}

The Corpus Christi Fairway contains high-temperature geothermal waters in the range of $300^{\circ}$ to $340^{\circ} \mathrm{F}$ $\left(149^{\circ}\right.$ to $\left.171^{\circ} \mathrm{C}\right)$ in both upper and lower Frio sandstones. Updip strandplain sandstones grade downdip across closely spaced fault zones into thin sandstone beds separated by thin shale beds representing shelf and slope deposits. Although sandstone-prone zones are 400 to $900 \mathrm{ft}(122$ to $274 \mathrm{~m})$ thick, individual sandstone beds 




Figure 7. Location of Ceneral Crude OiVDOE Pleasant Bayou Nos. 1 and 2 geopreseured-geothermal test wells (single location for both wells is at black dot) and structure on Frio T5 marker (Morton and others, 1983).

range in thickness from 1 to $10 \mathrm{ft}(0.3$ to $3.0 \mathrm{~m})$. Limited core data indicate that porosities range from 9 to 22 percent and permeabilities average less than $5.3 \mathrm{md}$

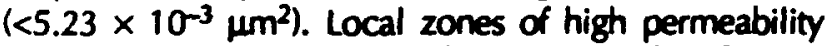
( 80 to 300 md $\left[7.90 \times 10^{-2}{\mu m^{2}}^{2}\right.$ to $\left.2.96 \times 10^{-1} \mu \mathrm{m}^{2}\right]$ ) exist at the top of some sandstones. Reservoirs in the Corpus Christi Fairway are relatively small because of restricted sand deposition and syndepositional and later faulting.

\section{Model V-Brazoria and Matagorda Fairways}

Along the upper Texas coast in Brazoria and Calveston Counties, thick, porous, and highly permeable lower
Frio sandstones accumulated in the Brazoria Fairway. Bebout and others (1978) mapped and identified the Brazoria Fainway as the most favorable site for testing geopressured-geothermal resources in the Frio Formation in Texas (fig. 5b). Sandstone reservoirs in the Matagorda Fainway are thin downdip equivalents of thick sandstone reservoirs in the Brazoria Faimay (Gregory and others, 1980). The Matagorda Fairway contains sandstone reservoirs with high fluid temperatures $\left(>340^{\circ} \mathrm{F}\left(>171^{\circ} \mathrm{C}\right)\right.$ ), but the reservoirs are thin and limited in lateral extent (Bebout and others, 1978). Ceological characterization of potential Tertiary geopressured-geothermal reservoirs led to the Austin Bayou Prospect (within the Brazoria Fairway) as a site for the first DOE design well to evaluate the geopressured-geothermal energy resource (fig. 7). 


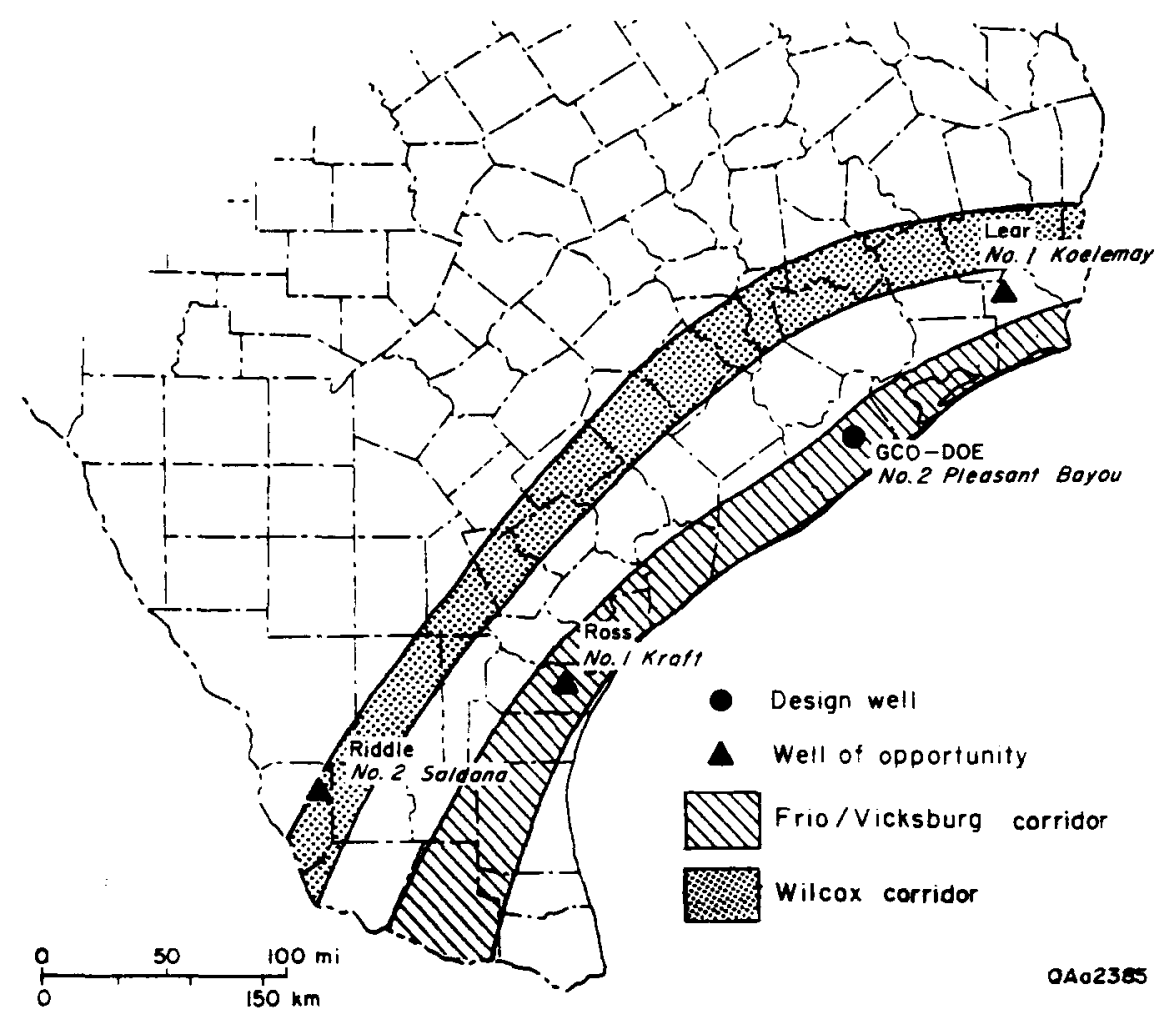

Figure 8. Location map of geopressured-geothermal corridors and geothermal test wells, Texas Culf Coast (Morton and others, 1983).

Structural style in the Brazoria Fairway represents the interaction between deltaic sedimentation, growth faulting, and salt dome growth. Thick reservoir sandstones accumulated in a large salt-withdrawal basin that is bounded on the updip side by a major regional growth fault. Several hundred feet of potential geothermal reservoir sandstones contain fluids at temperatures higher than $300^{\circ} \mathrm{F}\left(>149^{\circ} \mathrm{C}\right)$. Permeability values from cores of sandstone units in the Brazoria Fainway range from less than $0.1 \mathrm{md}\left(<9.87 \times 10^{-5} \mu \mathrm{m}^{2}\right)$ for cores with low porosities of less than 15 percent to several hundred millidarcys $\left(<140\right.$ to 1,050 md $\left[<1.38 \times 10^{-1} \mu \mathrm{m}^{2}\right.$ to $1.04 \mu \mathrm{m}^{2}$ ]) when porosity exceeds 20 percent. Ceneration of secondary porosity at reservoir depths has improved the permeability of Frio sandstones in the Brazoria Fairway (Loucks and others, 1980, 1981).

\section{DOE Geothermal Well Testing Program}

Reservoir data were collected from wells drilled in various potential geothermal reservoirs in Texas and
Louisiana (Could and others, 1981; Morton and others, 1983; Clark, 1985; Durrett, 1985; Carg and Riney, 1985; Pritchett and Riney, 1985; Rodgers and Durham, 1985; Rodgers and others, 1985). These wells include oil and gas wells drilled by industry and used for short-term tests (Wells of Opportunity program) and DOE geothermal wells used for long-term reservoir testing, characterization, and fluid production (Design Well program) (fig. 8). The short-term and long-term tests were designed to (1) document reservoir conditions, (2) define the productivity and life of the geothermal reservoir, (3) analyze geothermal fluids and dissolved gases, and (4) demonstrate potential for technical transfer to private companies.

\section{DOE Design Well Program}

Four design wells were drilled and tested (Lombard, 1985) (table 2). An additional well was drilled as a gas well and was transferred to DOE. The first design well, the Ceneral Crude-DOE Pleasant Bayou No. 1 was drilled in 1978 and completed as a disposal well after drill pipe became stuck in the geothermal section. Pleasant Bayou No. 2 was offset $500 \mathrm{ft}(152 \mathrm{~m})$ and 
Table 2a. Characteristics of geopressured-geothermal test wells. DOE design wells.*

\begin{tabular}{|c|c|c|c|c|c|}
\hline Well name & $\begin{array}{l}\text { General Crude/DOE } \\
\text { Pleasant Bayou No. } 2\end{array}$ & $\begin{array}{l}\text { Technadril-F and S/DOE } \\
\text { Gladys McCall No. } 1\end{array}$ & $\begin{array}{c}\text { Dow/DOE } \\
\text { L. R. Sweery Na. } 1\end{array}$ & $\begin{array}{l}\text { Gulf-Technadril/DOE } \\
\text { Amoco Fee No. } 1\end{array}$ & $\begin{array}{l}\text { Superior Oil Co. } \\
\text { Hulin No. } 1\end{array}$ \\
\hline Age/formation & Oligocene/Frio & Miocene/lower Miocene & Oligocene/Anahuac & Oligocene/Frio & Oligocene/Frio \\
\hline Unit & T5 sand & No. 8 sand & Cibicides jeffersonensis & $\begin{array}{l}\text { Miogypsinoides } \\
\text { (No. } 5 \text { sand) }\end{array}$ & Miogypsinoides \\
\hline Depth (ft) & 16,500 & $15,158-15,490$ & 13,340 & $15,387-15,414$ & 21,546 \\
\hline Thickness (ft) & 60 & 300 & 50 & 27 & 500 \\
\hline Bottom hole pressure (pwi) & 11,050 & 12,783 & 11,410 & 12,052 & 18,500 \\
\hline Flowing prescure (pai) & 3,000 & 2,000 & - & 4,749 & 3,500 \\
\hline Bottom hrole temperature ( $\left.{ }^{\circ} \mathrm{F}\right)$ & 301 & 298 & 237 & 279 & 360 \\
\hline Surface temperature ( $\left.{ }^{\circ} \mathrm{F}\right)$ & 292 & 268 & - & - & 330 \\
\hline Gas/water ratio & 23.7 & 27 & 17.5 & 20.9 & 34 \\
\hline Percent methane & 85 & 85 & - & - & 93 \\
\hline Percent $\mathrm{CO}_{2}$ & 10.5 & 10 & 10 & - & 4 \\
\hline Reservoir size (Bbbl) & 8 & 4 & - & - & 14 \\
\hline Total discolved solids (mg/L) & 131,320 & 95,000 & - & - & 195,000 \\
\hline $\mathrm{Cl}(\mathbf{m g} / \mathbf{l})$ & 70,000 & 57,000 & - & - & 115,000 \\
\hline Porosity (\%) & 19 & 23.8 & 27 & 20 & - \\
\hline Permeability (md) & 200 & 64 & $\begin{array}{c}6-1,526(817 \text { on } \\
\text { buildup) }\end{array}$ & $42-140$ & - \\
\hline Sustained flow rate & 20,000 & 19,837 & 9,800 & $2,046-2,648$ & 15,000 \\
\hline Long-term production (MMbbl) & 19.5 & 27.3 & - & 1.1 & - \\
\hline Limiting factors & $\begin{array}{l}\text { Well sanding when } \\
\text { production }>20,000 \mathrm{bbl}\end{array}$ & - & $\begin{array}{l}\text { Well sanding when } \\
\text { production }>10,000 \mathrm{bbl}\end{array}$ & $\begin{array}{l}\text { High production rates not } \\
\text { sustainable; reservoir } \\
\text { barriers }\end{array}$ & No long-term tests \\
\hline
\end{tabular}

-Modified from Klauzinski (1981), Monton (1981), Morton and others (1983), Clark (1985), Garg and Riney (1985), Peterson (1985), Negus-de Wys and others (1990), and Eaton Operating Company (1991). Dashes indicate information is not available. 
Table 2b. Characteristics of geopressured-geothermal test wells. DOE Wells of Opportunity.*

\begin{tabular}{|c|c|c|c|c|}
\hline Well name & $\begin{array}{l}\text { Riddle Saldana } \\
\text { No. } 2\end{array}$ & $\begin{array}{l}\text { Lear Koelemay } \\
\text { No. } 1\end{array}$ & $\begin{array}{c}\text { Ross Kraft } \\
\text { No. } 1\end{array}$ & $\begin{array}{l}\text { Wainoco Oil and Gas } \\
\text { P. R. Girouard No. } 1\end{array}$ \\
\hline Age/formation & Eocene/upper Wilcox & Eocene/Yegua & Oligocene/Frio & Oligocene/upper Frio \\
\hline Unit & First Hinnant & Leger sand & Anderson sand & Marginulina texana \\
\hline Depth (ft) & $9,745-9,835$ & $11,590-11,729$ & 12,750 & $14,720-14,827$ \\
\hline Gross sand thickness (ft) & 90 & 139 & 120 & 107 \\
\hline Net sand thickness (ft) & 79 & 77 & 109 & 91 \\
\hline Bottom hole preseure (psi) & 6,627 & 9,450 & 10,986 & 13,203 \\
\hline Shut-in surface presoure (psi) & 2,443 & 4,373 & 9,507 & 6,695 \\
\hline Bottom-hole temperature ( $\left.{ }^{\circ} \mathrm{F}\right)$ & 300 & 260 & 263 & 274 \\
\hline Gas/water ratio & $47-54$ & 30 (plus gas cap) & - & 40 (estimate) \\
\hline Total dissolved solids (mg/L) & 13,000 & 15,000 & 23,000 & 23,500 \\
\hline Porosity $(\%)$ & 20 & 26 & 23 & 26 \\
\hline Permeability (md) & 7 & 85 & 39 & - \\
\hline Sustained flow rate & 1,950 & - & 34 & 15,000 \\
\hline Limiting factors & Tight & Restricted reservoir & Damaged reservoir & Restricted reservoir \\
\hline
\end{tabular}

"Modified from Klauzinski (1981), Morton (1981), Morton and others (1983), Clark (1985), Carg and Riney (1985), Peterson (1985), Negus-de Wys and others (1990), and Eaton Operating Company (1991). Dashes indicate information is not available. 
successfully completed to $16,500 \mathrm{ft}(5,029 \mathrm{~m})$ in 1979 (Bebout and others, 1978; Morton and others, 1983). The DOE Pleasant Bayou No. 2, in Brazoria County, Texas, is the only well in the geothermal-geopressured program that has successfully produced energy. An experimental hybrid power system (Hughes and Campbell, 1985; Eaton Operating Company, 1991) produced approximately 1 megawatt per day through (1) a binary-cycle turbine utilizing heat from geothermal brines to vaporize isobutane and (2) gas-engine combustion heat from separated natural gas. Natural gas from this well was also sold to a pipeline. This test extended from September 1989 to June 1990. The DOE Pleasant Bayou No. 2 sustained production of 20,000 to $23,000 \mathrm{bbl} / \mathrm{d}\left(3.68 \times 10^{-2} \mathrm{~m}^{3} \mathrm{~s}^{-1}\right.$ to $\left.4.23 \times 10^{-2} \mathrm{~m}^{3} \mathrm{~s}^{-1}\right)$ of brine at a well-head temperature of $268^{\circ} \mathrm{F}\left(131^{\circ} \mathrm{C}\right)$ (Eaton Operating Company, 1991). Approximately $20 \mathrm{MMbbl}\left(\sim 3.18 \times 10^{6} \mathrm{~m}^{3}\right)$ have been withdrawn, and $39 \mathrm{MMcf}\left(1.10 \times 10^{6} \mathrm{~m}^{3}\right)$ of gas were extracted from the well's estimated $7.8 \mathrm{Bbbl}\left(1.24 \times 10^{9} \mathrm{~m}^{3}\right)$ fluid reservoir (Eaton Operating Company, 1991). The test facility successfully dernonstrated the ability to convert multicomponent geopressured-geothermal energy into useful power. However, the costs of electricity and gas produced from the test were not economically viable when compared with that produced from conventional energy resources.

\section{DOE Wells of Opportunity Program}

The DOE Wells of Opportunity program used existing oil and gas wells for short-term reservoir tests. Six conventional oil and gas wells that were tested in the program during 1980 and 1981 sustained fluid production rates of 1,950 to $15,000 \mathrm{bbl} / \mathrm{d}\left(3.59 \times 10^{-3} \mathrm{~m}^{3} \mathrm{~s}^{-1}\right.$ to $2.76 \times 10^{-2} \mathrm{~m}^{3} \mathrm{~s}^{-1}$ ) from conventional $23 / 8$ - to $31 / 2$-inch (6.0- to 8.9-cm) tubing (Klauzinski, 1981). Riddle No. 2 Saldana in Martinez field, Zapata County, South Texas, is a well of opportunity that has tested the First Hinnant sandstone (upper Wilcox), which correlates with the Live Oak delta complex in McMullen and Live Oak Counties (Morton and others, 1983). This well provides the most direct data on the geothermal well productivity of the upper Wilcox in South Texas. The sandstone has good reservoir continuity and poor to excellent reservoir quality. For the Riddle No. 2 Saldana, average porosity from the sonic log was 16 percent, average permeability was $7 \mathrm{md}\left(6.91 \times 10^{-3} \mu \mathrm{m}^{2}\right)$, salinity was $13,000 \mathrm{ppm}$ TDS, maximum temperature was $300^{\circ} \mathrm{F}\left(149^{\circ} \mathrm{C}\right)$ (Morton and others, 1983), and maximum flow rate was $1,950 \mathrm{bbl} / \mathrm{d}\left(3.59 \times 10^{-3} \mathrm{~m}^{3} \mathrm{~s}^{-1}\right)$ (table 2$)$.

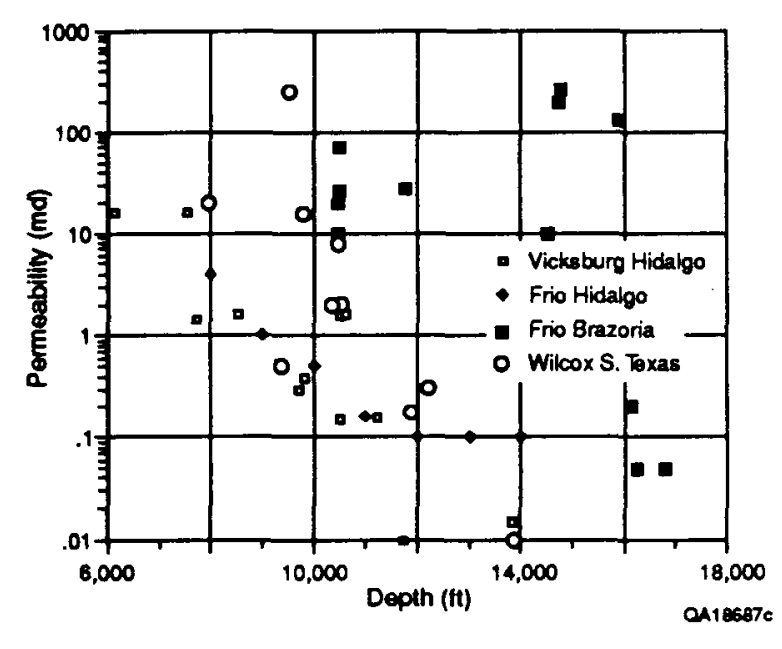

Figure 9. Average permeability plotted as a function of depth for various Texas geothermal corridors: Wilcox (Klauzinaki, 1981; Bebout and others, 1982; Morton and others, 1983); Vicksburg (Swanson and others, 1976; Loucks, 1979); and Frio (Bebout and others, 1978; Morton and others, 1983).

Average permeability data from previous geopressured-geothermal research programs (fig. 9) represent permeabilities derived from diamond core, sidewall core, drill-stem tests, pumping tests, and median values averaged from many samples. These undesirable variations in measurement techniques impose an additional scatter to data that characteristically have a wide natural dispersion. Despite the scatter in the data, there is a clear distinction between the relatively low permeabilities of Vicksburg, Frio, and Wilcox strata in South Texas and the extraordinarily high permeabilities measured in the Frio in the Brazoria Fainway. In the South Texas area, where Wilcox and younger Tertiary strata are deeply buried $(11,000$ to $14,000 \mathrm{ft}[3,353$ to $4,267 \mathrm{ml})$ in the hot geothermal zone, typical permeabilities range from less than 0.01 to $1 \mathrm{md}$

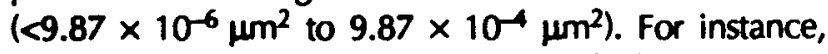
Morton and others (1983) reported that average permeability was $17 \mathrm{md}\left(1.68 \times 10^{-2} \mu^{2}\right)$ in the First Hinnant sandstone (17 measurements) over a depth range of 9,720 to $9,840 \mathrm{ft}(2,963$ to $2,999 \mathrm{~m})$ at the Riddle No. 2 Saldana. In contrast, at Pleasant Bayou No. 2, average permeabilities are $230 \mathrm{md}\left(2.27 \times 10^{-1} \mu \mathrm{m}^{2}\right)$ in the Andrau Sand (27 measurements) over a depth range of 14,484 to $14,766 \mathrm{ft}(4,415$ to $4,501 \mathrm{~m}$ ) (Morton and others, 1983, p. 54-57). Rosita field in Duval County, an upper Wilcox gas field from which abundant 


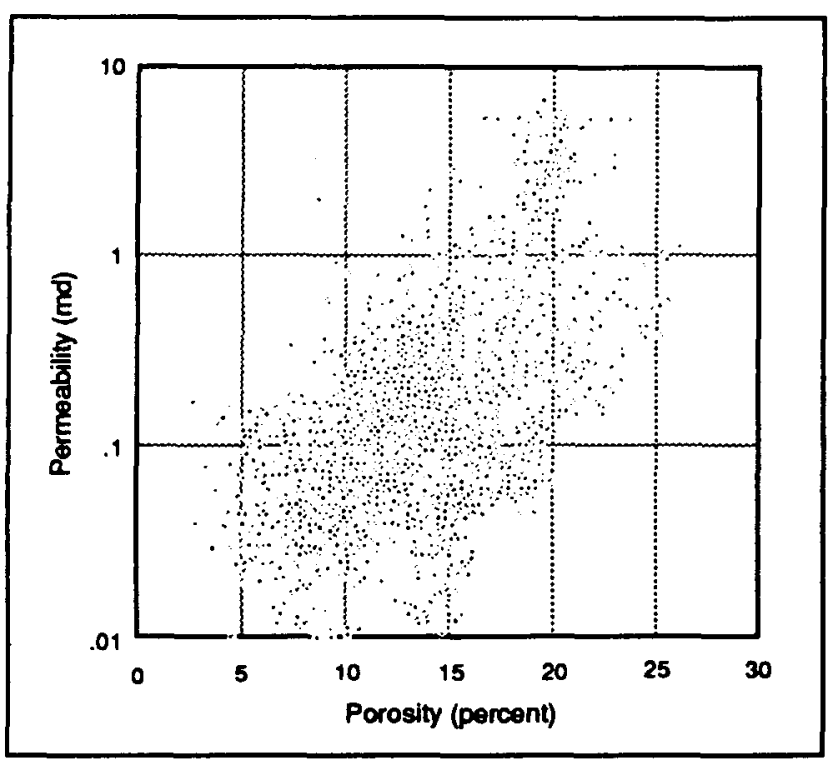

Figure 10. Permeability (unstressed air permeability) versus porosity in upper Wilcox gas wells, Duval County, Texas.

porosity/permeability data are available, shows that in the deepest and hottest reservoirs, most permeability values are less than $1 \mathrm{md}\left(<9.87 \times 10^{-4}{\left.\mu \mathrm{m}^{2}\right)}^{2}\right.$ (fig. 10). Permeabilities from the Frio Pleasant Bayou No. 2 geothermal well in Brazoria County, when compared with those from the upper Wilcox Fandango field in Zapata County (fig. 11), are typically one to two orders of magnitude greater for a given constant porosity.

\section{Summary of}

\section{Geopressured-Geothermal Resources in Texas}

The thick reservoir sandstones and locally high porosity and permeability characterize reservoirs of model $V$ in the Frio Formation of the central Texas Gulf Coast as the most favorable for production of geopressured-geothermal resources in Texas. Both the Frio Formation and Wilcox Group contain sandstone reservoirs of sufficient thickness and temperature to be viable geothermal resources. Maximum temperatures of thick reservoir sandstones in the Frio are approximately $300^{\circ} \mathrm{F}\left(-149^{\circ} \mathrm{C}\right)$. Locally, upper Wilcox reservoirs (model 1) contain geothermal fluids in excess of $450^{\circ} \mathrm{F}\left(>232^{\circ} \mathrm{C}\right)$ and thick reservoir sandstones. The favorable trend of high fluid temperature, low salinity/high gas saturation, and thick reservoir sandstone in the South Texas Wilcox Group must be balanced

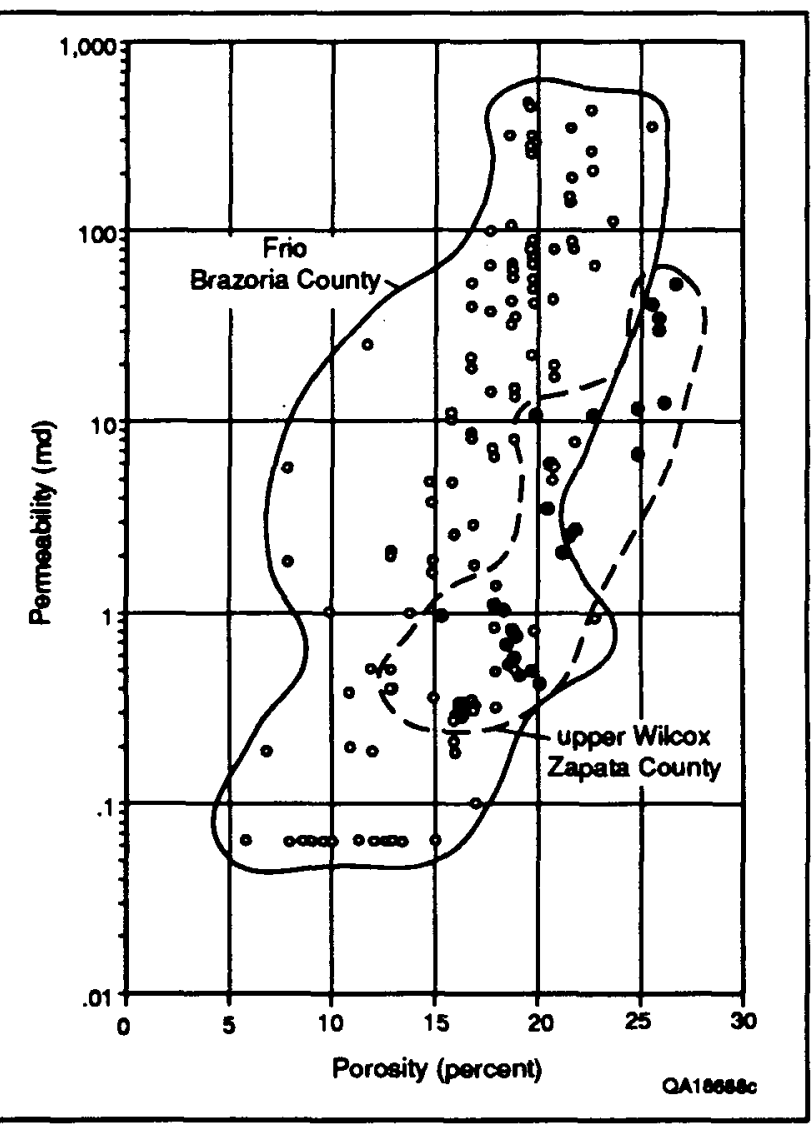

Figure 11. Permeability (unstressed air permeability) versus porcesty, Frio Chocolate Bayou field, Brazoria County, Texas, and an upper Wilcox field in Zapata County, South Texas.

against the consistent trend of decreasing porosity and permeability with depth.

The limiting factor affecting geothermal productivity is the low permeability of potential reservoir sandstones. Low permeability is endemic for South Texas Wilcox, Frio, and Vicksburg Fairways (Swanson and others, 1976; Bebout and others, 1978, 1982; Loucks, 1979). Comparison of porosity/permeability relationships between South Texas Wilcox reservoirs and ideally favorable Frio resenoirs along the central Texas Gulf Coast indicates that the Frio reservoirs at similar reservoir depth typically have permeabilities that are one to two orders of magnitude greater. The abundance of unstable volcanic rock fragments in South Texas favors a burial diagenesis pathway that results in reduction of original primary porosity by cementation. Along the middle Texas coastal area, secondary porosity by feldspar dissolution in the deep subsurface (Loucks and others, 1980, 1981; Milliken and others, 1981) has enhanced porosity and permeability of deeply buried sandstones. 


\section{Direct Use of Geothermal Fluids for Improved Oil Recovery}

The role of hot-water flooding in the mobilization of heavy oil is poorly documented (DuBar, 1990), and relatively few field applications have been designed to assess the effectiveness of hot-water floods to increase production of heavy crude. Important exceptions are the pilot test in the Schoonebeek field, the Netherlands (Dietz, 1972), and the Loco field in southern Oklahoma (Martin and others, 1972). According to DuBar (1990), these two tests demonstrated that, although the process was more complicated than originally anticipated, hotwater flooding could increase heavy-oil production. Currently, Amoco Production Company is using geathermal fluids in a hot-water flood of oil reservoirs in Wyoming (Lunis, 1990).

\section{Hot-Water Flooding}

Raising the temperature of the reservoir and the oil is the primary method employed in thermal recovery techniques for decreasing in situ viscosities and increasing production from heavy-oil reservoirs. Hot-water flooding is one method of heating the reservoir to decrease the oil viscosity and thus improve the displacement efficiency over that obtainable from conventional waterfoods (Craig, 1971). Hot-water flooding is essentially a displacement process in which both hot and cold water mobilize oil. A hot-water flood, whether using geothermally heated fluids or conventionally heated water, involves the flow of two phases: water and oil. Steam and combustion processes include a third, gaseous, phase. The displacement efficiency of hot water is greater than that of cold water, but much less than that of steam (fig. 12). Hot water has a lower transport capacity and sweep efficiency than steam injection (Burger and others, 1985).

Burger and others (1985) showed schematically how (1) thermal expansion, (2) viscosity reduction, (3) wettability, and (4) oil/water interfacial tension affect displacement efficiency of crudes of varying oil density (fig. 13). Qualitatively, viscosity reduction is the most important mechanism that contributes to increasing displacement efficiency of heavy crudes, whereas thermal expansion is more important in displacing light crudes. Burger and others (1985) recognized three principal zones that develop in a reservoir flooded by hot water (fig. 14):

Zone 1: At each point in the heated zone, the temperature increases with time, which reduces the

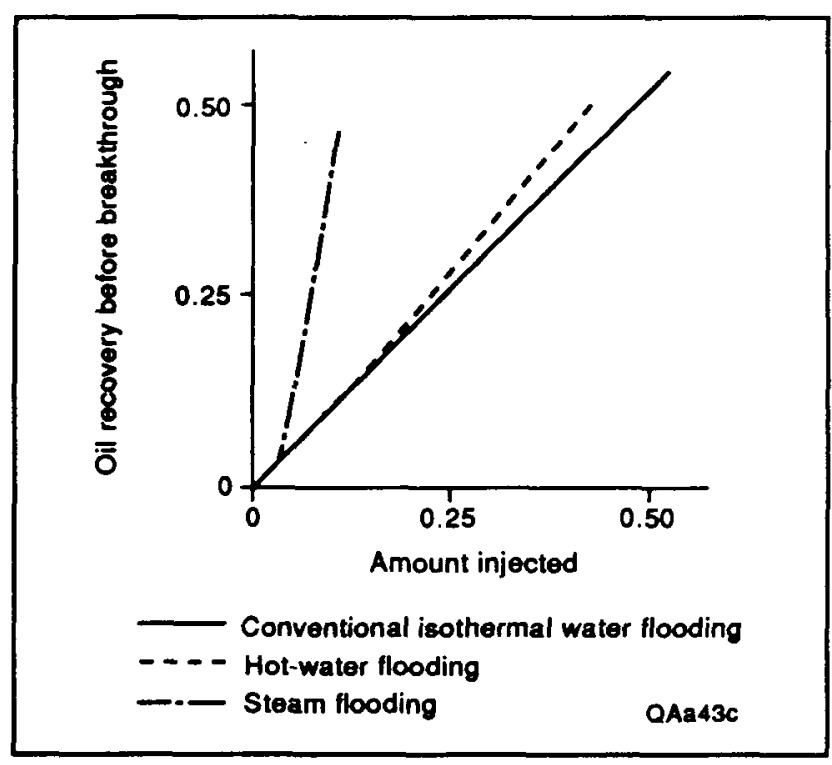

Figure 12. Oil recovery before breakthrough of water versus the amount of water injected: curve $A$ comventional (cold) water flood, curve B-hot water flood, and curve $\mathbf{C} \rightarrow$ steam flood. Modified from Burger and others (1985); printed by permission of the publisher.

residual oil saturation. The temperature within the reservoir decreases with increasing lateral distance from the injection well. In addition, expansion of fluids and matrix leads to a reduction of the specific gravity of the oil left in the pore space at the same saturation.

Zone 2: Oil is being displaced by water that has cooled to the temperature of the formation. The oil saturation at any point in the zone will decrease with time, and under certain conditions may reach residual saturation corresponding to the prevailing temperature in the zone. The oil saturation will then increase with increasing lateral distance from the injection well.

Zone 3: Reservoir conditions in this zone are consistent with the ambient conditions that existed before the hot fluids were injected. In contrast to the three zones that develop during injection of hot water, four zones develop during steam injection: (1) the steam zone, (2) the condensation zone, (3) the hot-water zone, and (4) the unaffected zone (Burger and others, 1985).

Heavy-oil reservoirs are the focus of the colocation research program because literature and laboratory data 


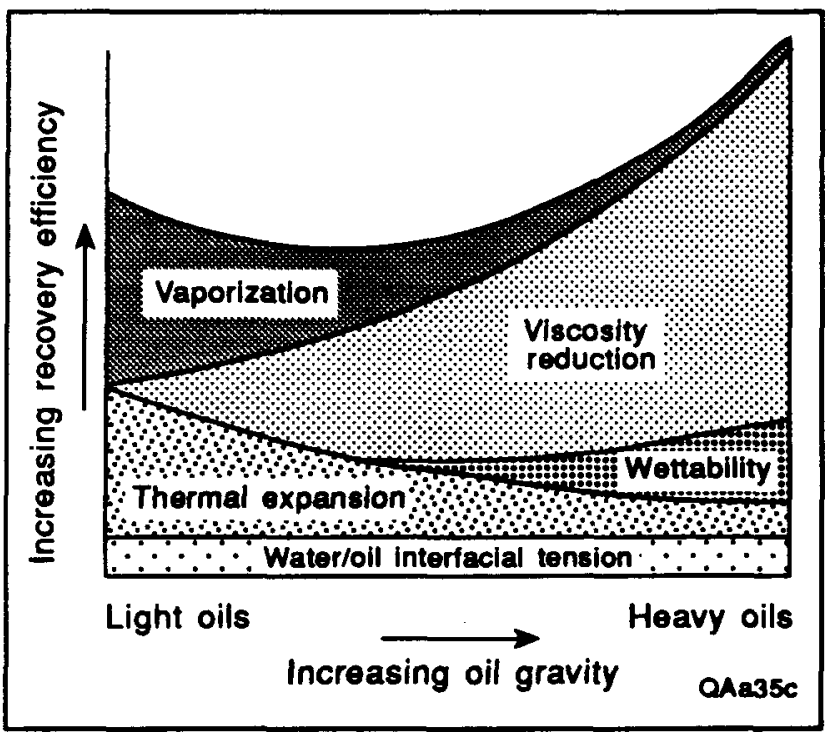

Figure 13. Relative contribution of viscosity reduction, vaporization, themal expansion, wettability, and water/ oil interfacial tension to the improvement of oil displacement by hot water or steam. In oils with high densities, reduction in viscosity is the most important process. Modified from Burger and others (1985); printed by permission of the publisher.

indicated that heavy oil from these reservoirs would exhibit a greater visccsity reduction during hot-water flooding than would light oil (Tissot and Welte, 1984; Negus-de Wys and others, 1991). Traditionally, oil is classified primarily by its API gravity, and a heavy oil has an API gravity greater than $10^{\circ}$ and less than or equal to $20^{\circ}$ (Lane and Carton, 1925; Smith, 1968; Tissot and Welte, 1984). The boundary of $20^{\circ}$ API gravity between heavy and medium oil, however, is not universally accepted. North (1985) used $22^{\circ}$ as the boundary between heavy and medium oil. In some areas characterized by abundant light oil, such as the Arabian Peninsula, oil below $27^{\circ}$ is considered heavy (North, 1985).

In this report, heavy oil is defined as having API gravity between $10^{\circ}$ and $20^{\circ}$, viscosities of 100 to 10,000 centipoise (cP) (1 to $\left.100 \mathrm{~g} \mathrm{~cm}^{-1} \mathrm{~s}^{-1}\right)$ at reservoir conditions, and specific gravity of 0.93 to $1.0 \mathrm{~g} \mathrm{~cm}^{-3}$ (Tissot and Welte, 1984). Medium oil is defined as having API gravity between $20^{\circ}$ and $25^{\circ}$. Dense, viscous oils having low API gravities and high viscosity characterize the heavy oils reported in this study. Viscosity, the internal friction of a fluid that causes resistance to flow, is defined by force $\times$ distance / area $\times$ velocity. Oil viscosities are commonly unavailable in public sources of information, whereas oil densities and API gravities are typically reported. Viscosities vary directly with densities, and thus oil viscosity is a function of the number of carbon atoms and the amount of gas dissolved in the oil (North, 1985). According to Tissot and Welte (1984), API gravity is strongly correlated (correlation coefficient of 0.916 for high-sulfur crude oils) to log viscosity. According to Negus-de Wys and others (1991), for $20^{\circ}$ API-gravity oil at a reservoir temperature of $86^{\circ} \mathrm{F}\left(30^{\circ} \mathrm{C}\right)$, viscosity can be reduced by an order of magnitude from 100 to $10 \mathrm{cP}$ (1.0 to $1.0 \times 10^{-1} \mathrm{~g} \mathrm{~cm}^{-1} \mathrm{~s}^{-1}$ ) if reservoir temperature is increased to $212^{\circ} \mathrm{F}\left(100^{\circ} \mathrm{C}\right)$. The operational difficulty is in distributing heat throughout the reservoir and avoiding channeling of injected hot fluids. The disadvantages of hot-water flooding are substantially mitigated if an ample supply of geothermally heated water exists near a heavyoil reservoir.

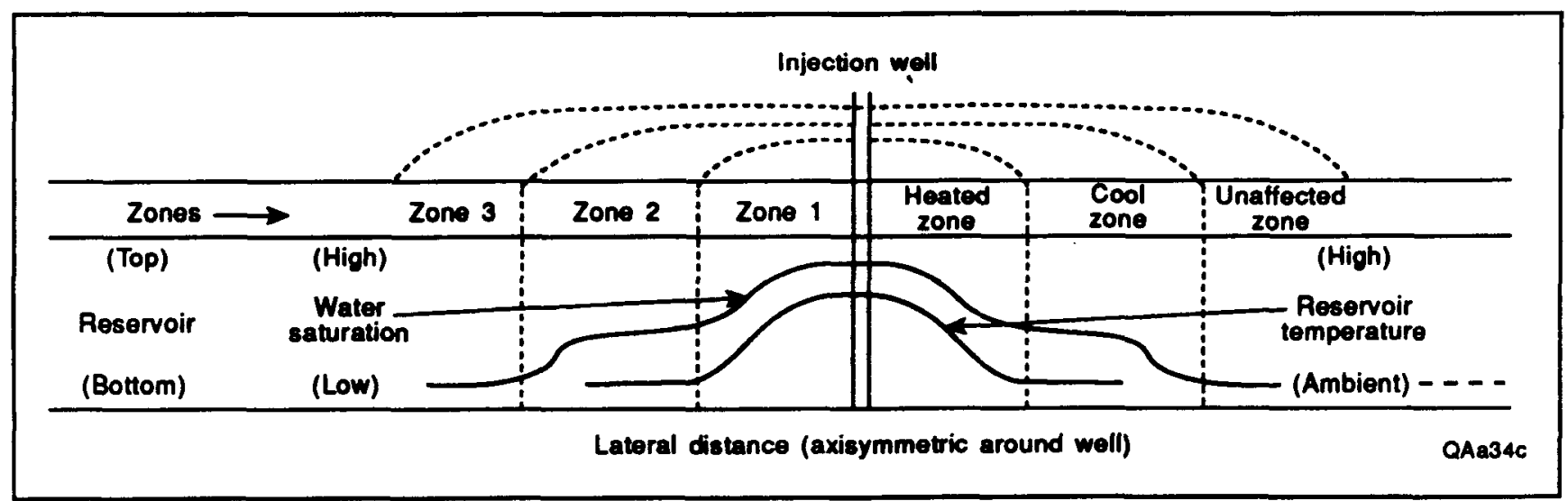

Figure 14. Displacement zones, water saturation, and temperature profiles around a well bore during injection of hot water into a heavy-oil reservoir. Zone 1-heated zone, zone 2-cod zone, and zone 3-unaffected zone. Excludes the effects of vaporization of the light fractions of the oil, themal overnuming within the reservoir, and resenvoir heterogeneities. Modified from Bunger and others (1985); printed by permission of the publisher. 


\section{Heavy Oil in Texas}

Heavy-oil fields compose approximately 25 percent of the 100 largest fields in the United States in terms of 1980 reserves (Interstate Oil Compact Commission, 1984). Reservoirs containing heavy oil are concentrated in California and Texas; the two states respectively contain 32 and 31 percent of the nation's 1,108 heavy-oil reservoirs (Interstate Oil Compact Commission, 1984). Heavy-oil fields in California have produced more than $12 \mathrm{Bbbl}\left(>1.91 \times 10^{9} \mathrm{~m}^{3}\right)$ of oil (Interstate Oil Compact Commission, 1984), and thermal recovery techniques, such as steam flooding or cyclic steam injection, are commonly used to improve recovery from these fields. Ten percent of the large oil reservoirs in Texas ("large" reservoirs are defined as those having a cumulative production greater than $\left.10 \mathrm{MMbbl}\left[>1.59 \times 10^{6} \mathrm{~m}^{3}\right]\right)$ produce medium and heavy oil (Galloway and others, 1983). In Texas, medium- and heavy-oil reservoirs, like light-oil resenoirs, are typically produced without thermal recovery techniques. These medium- and heavy-oil reservoirs represent an underutilized resource because high oil viscosities result in low average recovery efficiencies of 20 to 35 percent (Galloway and others, 1983; Interstate Oil Compact Commission, 1984). In contrast, recovery efficiencies for light-oil reservoirs average 50 percent (Calloway and others, 1983).

\section{Data Sources}

To assess the potential of geothermal fluids for enhanced recovery of heavy oil, a review was conducted during this study to determine the distribution of mediumand heavy-oil reservoirs in Texas. The Railroad Commission of Texas' annual report is the primary source of public information on oil and gas reservoirs in Texas. Although the Railroad Commission of Texas does not report reserves, reservoir data include depth, API gravity, current annual production, and cumulative production.

Galloway and others (1983) selectively analyzed large Texas oil reservoirs with production of greater than $10 \mathrm{MMbbl}\left(>1.59 \times 10^{6} \mathrm{~m}^{3}\right)$ and grouped reservoirs into geologically defined plays. Reservoir statistics for the large oil resenoirs in Texas that originally were tabulated in Galloway and others (1983) were computerized and updated (cumulative production statistics current to January 1, 1990) by Tyler and others (1991). The 460 large oil reservoirs studied by Galloway and others (1983) represent approximately 70 percent of the total state oil production. Logically, these large reservoirs represent the most favorable resource targets for TEOR because their larger resource base, in comparison with that of small oil reservoirs, is needed to support the additional infrastructure expense of developing geothermal fluids. Previous compilations of the heavy-oil (and tar sands) resources in the United States include Ball and Associates (1962) and the Interstate Oil Compact Commission (1984). The Interstate Oil Compact Commission (1984) provided detailed field reports on major tar sands in the United States (typically fields with API gravity $<10^{\circ}$ ) and listed public information on the heavy-oil fields (API gravity between $10^{\circ}$ and $20^{\circ}$ ).

\section{Texas Medium- and Heavy-Oil Plays}

Plays containing multiple large medium- and heavyoil reservoirs are concentrated along the Texas Gulf Coast and in the East Texas Basin (fig. 15). The play, API gravity, depth, and cumulative production for all mediumand heavy-oil reservoirs in Texas that have exceeded 10 MMbbl ( $\left.>1.6 \times 10^{6} \mathrm{~m}^{3}\right)$ cumulative production are listed in table 3 (Tyler and others, 1991). These medium- and heavy-oil reservoirs account for $\mathbf{8 . 4}$ percent of the total oil production from the large reservoirs in Texas (table 4). The API gravity of the large reservoirs is strongly dependent on resenvoir depth (fig. 16). The dominant trend is for the oils to become heavier (lower API gravity) and more viscous with decreasing depth. All heavy-oil resenoirs are shallower than $6,000 \mathrm{ft}(<1,828 \mathrm{~m})$ and have an average depth of less than $3,200 \mathrm{ft}(<975 \mathrm{~m})$. The average depth of the medium-oil reservoirs is 3,500 $\mathrm{ft}(1,067 \mathrm{~m})$. The average size of the heavy-oil reservoirs (125 MMbbl [2.0 $\left.\times 10^{7} \mathrm{~m}^{3}\right]$ ), on the basis of cumulative production (table 2), is large, reflecting the few (9) large heavy-oil reservoirs and the inclusion of one supergiant reservoir-Hawkins Woodbine-that has a cumulative production of $814 \mathrm{MMbbl}\left(1.3 \times 10^{8} \mathrm{~m}^{3}\right)$.

The gravity of oil varies among a group of related reservoirs and even between wells within a single reservoir. Despite this variability, reasonable trends are illustrated in figure 17 for average API gravity and depth of all reservoirs within plays of the large Texas oil reservoirs. As in individual reservoirs, the average API gravity in shallow plays is lower than the average API 


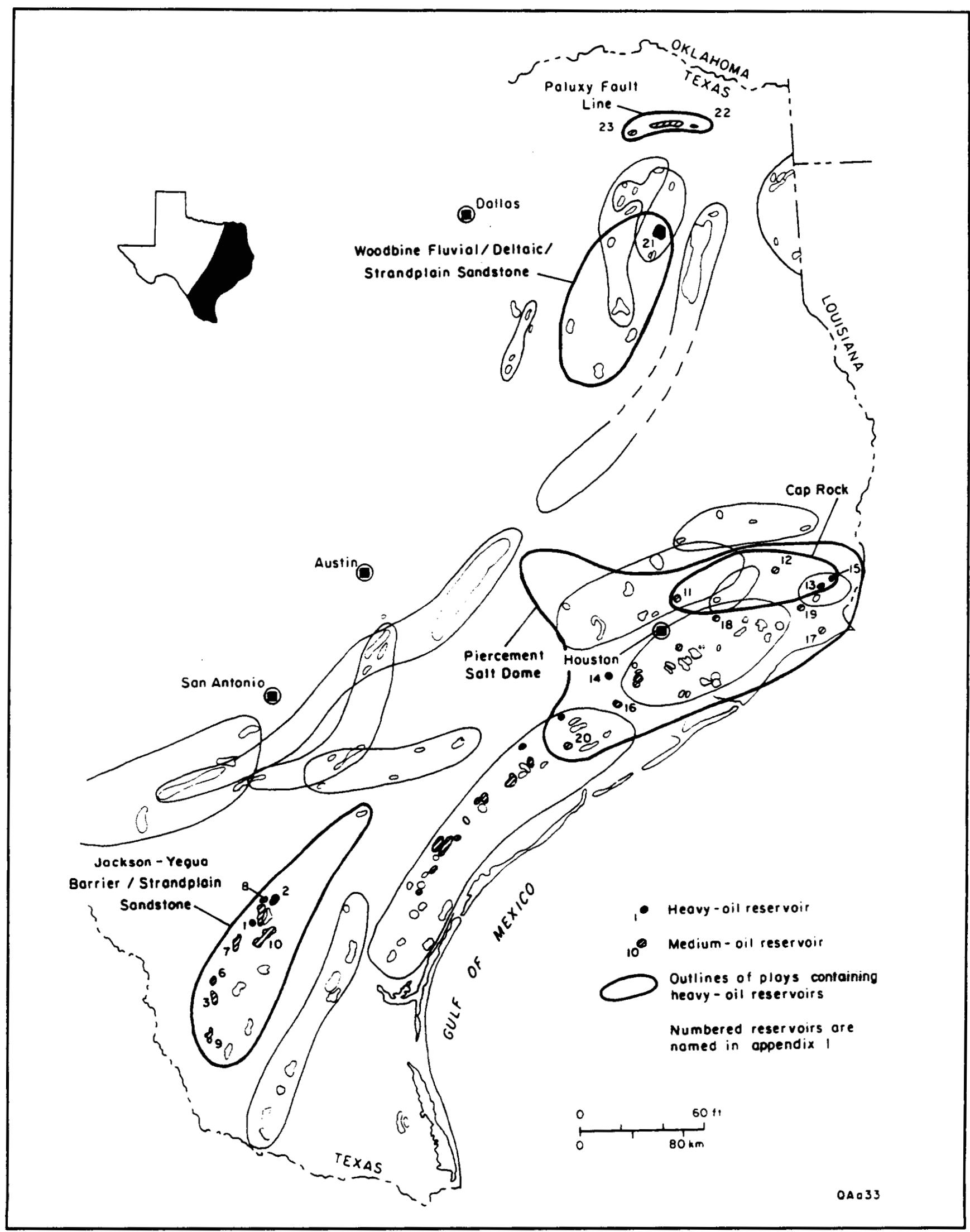

Figure 15. Map of oil plays in Texas containing medium- to heavy-oil reservoirs. Modified from Galloway and others (1983). Names of fields and reservoirs are listed in appendix 1. 
Table 3. Production statistics from large oil reservoirs in Texas.*

\begin{tabular}{|c|c|c|c|c|}
\hline Field and reservoir & Play & $\begin{array}{l}\text { APl gravity } \\
\text { (degrees) }\end{array}$ & $\begin{array}{l}\text { Depth } \\
\text { (ft) }\end{array}$ & $\begin{array}{l}\text { production } \\
\text { (MMbbl) }\end{array}$ \\
\hline Big Creek & Salt Dome & 18 & 4,500 & 25.173 \\
\hline Olson & San Andres/Ozona Arch & 18 & 1,800 & 14.04 \\
\hline Pewitt Ranch Paluxy & Paluxy Fault & 19 & 4,300 & 23.378 \\
\hline Port Neches & Salt Dome & 19 & 6,000 & 24.568 \\
\hline Toborg, Cretaceous & Yates Area & 19 & 500 & 41.231 \\
\hline Hawkins, Woodbine & Woodbine Sandstone & 19 & 4,500 & 814.212 \\
\hline Lundell & Jackson/Yegua & 19 & 1,500 & 10.4 \\
\hline Seven Sisters, G. W. & Jackson/Yegua & 20 & 2,330 & 55.955 \\
\hline Aviators, Mirando & Jackson/Yegua & 21 & 1,700 & 10.37 \\
\hline Govt. Wells N & JacksonYYegua & 21 & 2,200 & 80.026 \\
\hline Govt. Wells S & Jackson/Vegua & 21 & 2,300 & 18.148 \\
\hline Mirando City, Mirando & Jackson/regua & 21 & 1,600 & 12.302 \\
\hline Sulphur Bluff, Paluxy & Paluxy Fault & 21 & 4,500 & 32.136 \\
\hline Damon Mound & Salt Dome & 21 & 3,800 & 16.941 \\
\hline Houston S, Miocene & Frio Deep-Seated Dome & 22 & 4,000 & 14.9 \\
\hline Humble, Cap Rock & Cap Rock & 22 & 1,200 & 168.134 \\
\hline Lopez First, Mirando & Jackson/Yegua & 22 & 2,200 & 31.352 \\
\hline Piedre Lumbre, G. W. & Jackson/Yegua & 22 & 1,900 & 21.128 \\
\hline Sour Lake, Cap Rock & Cap Rock & 22 & 600 & 132.749 \\
\hline Spindletop, Cap Rock & Cap Rock & 22 & 800 & 154.681 \\
\hline Talco, Paluxy & Paluxy Fault & 22 & 4,300 & 279.615 \\
\hline Bloomington, 46.00 & Frio Barrier/Strandplain & 23 & 4,600 & 31.568 \\
\hline Escobas, Mirando & Jackson/Yegua & 23 & 1,200 & 13.067 \\
\hline Hoffman, Dougherty & Jackson/Yegua & 23 & 2,000 & 48.805 \\
\hline Taft, 4000 & Frio Barrier/Strandplain & 23 & 4,000 & 25.284 \\
\hline Clam Lake & Salt Dome & 23 & 1,179 & 12.79 \\
\hline Bonnie View & Frio Barrier/Strandplain & 24 & 4,500 & 19.624 \\
\hline Gannado W, 4700 & Frio Barrier/Strandplain & 24 & 4,700 & 27.6 \\
\hline Greta, 4400 & Frio Barrier/Strandplain & 24 & 4,400 & 133.232 \\
\hline Lake Pasture, H-440 S & Frio Barrier/Strandplain & 24 & 4,500 & 51.815 \\
\hline Placedo, 4700 sand & Frio Barrier/Strandplain & 24 & 4,700 & 43.076 \\
\hline Tom O'Connor, 4400 & Frio Barrier/Strandplain & 24 & 4,400 & 14.22 \\
\hline Tom O'Connor, 4500 & Frio Barrier/Strandplain & 24 & 4,500 & 18.895 \\
\hline Weigang, Carrizo & Wilcox Fluvial/Deltaic & 24 & 3,900 & 11.193 \\
\hline West Ranch, Greta & Frio Barrier/Strandplain & 24 & 5,100 & 99.237 \\
\hline Westbrook & East Shelf Permian Carb. & 24 & 2,900 & 90.737 \\
\hline Barbers Hill & Salt Dome & 24 & 7,200 & 131.067 \\
\hline Maurbro, Marginulina & Frio Barrier/Strandplain & 25 & 5,200 & 26.031 \\
\hline McFaddin, 4400 & Frio Barrier/Strandplain & 25 & 4,400 & 30.334 \\
\hline Pickett Ridge & Frio Barrier/Strandplain & 25 & 4,700 & 16.077 \\
\hline Quitman, Eagle Ford & Cretaceous Sandstone & 25 & 4,200 & 10.654 \\
\hline Thompson, Frio & Frio Deep-Seated Dome & 25 & 5,400 & 360.417 \\
\hline Thompson S, 4400 & Frio Deep-Seated Dome & 25 & 4,400 & 24.798 \\
\hline Thompson S, 5400 & Frio Deep-Seated Dome & 25 & 5,300 & 10.7 \\
\hline Fannett & Salt Dome & 25 & 8,350 & 53.88 \\
\hline Markham & Salt Dome & 25 & 4,385 & 17.917 \\
\hline
\end{tabular}

*Statistics current as of January 1, 1990. List generated from data in Tyler and others (1991). 
Table 4. Comparative statistics of large heavy-, medium-, and light-oil reservoirs in Texas.*

$\begin{array}{lccccc}\text { Category } & \begin{array}{c}\text { Reservoirs } \\ \text { (number) }\end{array} & \begin{array}{c}\text { Total } \\ \text { production } \\ \text { (MMbbl) }\end{array} & \begin{array}{c}\text { Production } \\ \text { (percentage) }\end{array} & \begin{array}{c}\text { Average } \\ \text { reservoir production } \\ \text { (MMbbl) }\end{array} & \begin{array}{c}\text { Average } \\ \text { depth } \\ \text { (ft) }\end{array} \\ \text { Heavy oil } & 8 & 999 & 2.5 & 125 & 3,178 \\ \text { Medium oil } & 38 & 2,296 & 5.8 & 60 & 3,506 \\ \text { Light oil } & 415 & 36,046 & 91.6 & 87 & 6,173 \\ \text { Total } & 461 & 39,340 & 100.0 & 85 & 5,940\end{array}$

*List generated from data in Tyler and others (1991).

gravity in the deeper plays. Five plays containing medium- and heavy-oil reservoirs are significant for TEOR: Jackson-Yegua Barrier/Strandplain Sandstone, Cap Rock, Piercement Salt Domes, Paluxy Fault Line, and Woodbine Fluvial/Deltaic/Strandplain Sandstone. Of these five plays, four are characterized by a shallow average reservoir depth of less than $4,500 \mathrm{ft}(<1,370 \mathrm{~m})$, low average API gravity of less than $29^{\circ}$, and tight grouping greater than one standard deviation below the API depth trend line. The Cap Rock and Paluxy Fault Line plays both contain a small number of reservoirs, and the individual reservoirs are in an advanced stage of

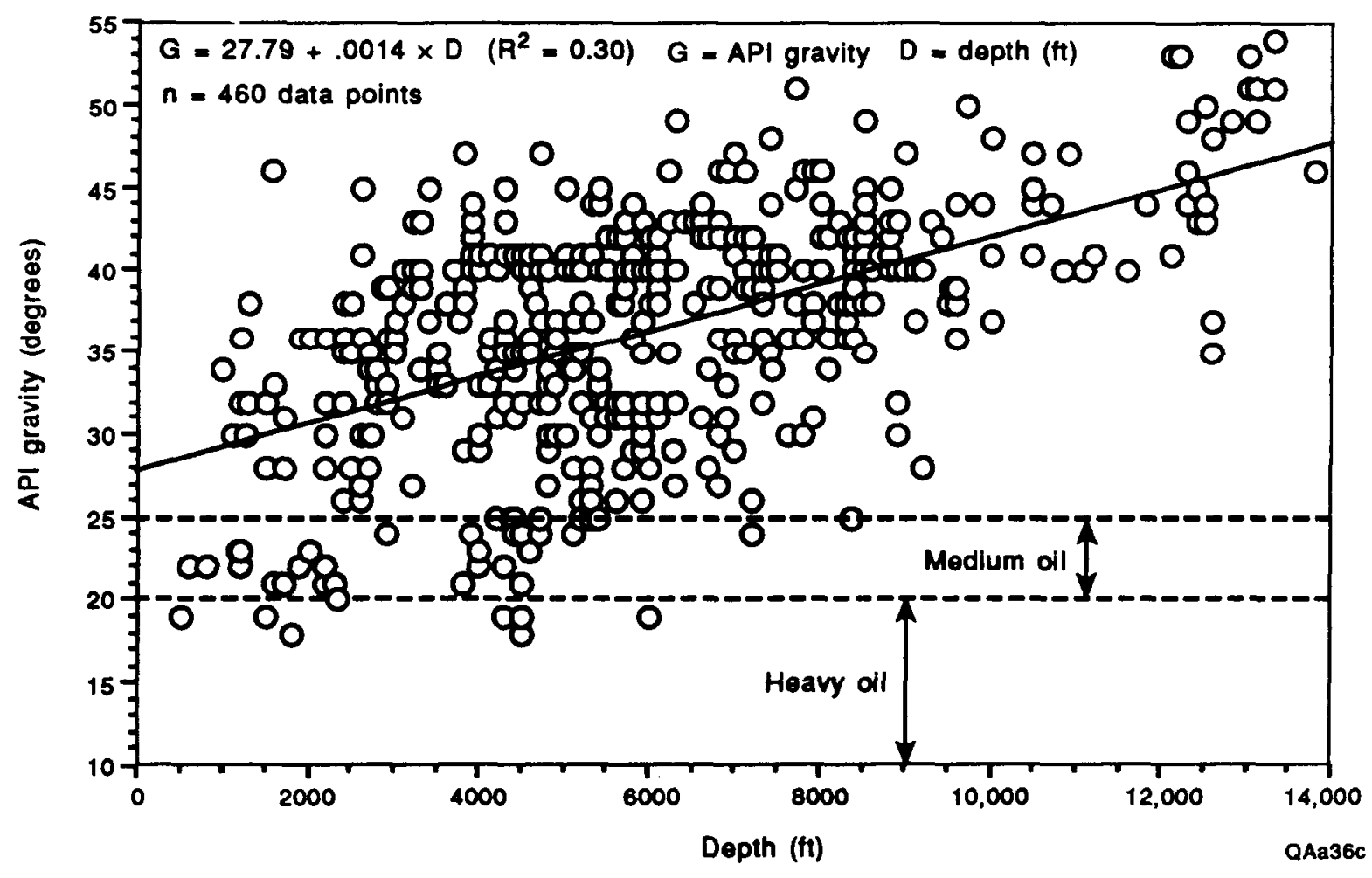

Figure 16. Graph of API gravity versus depth for all large oil reservoirs in Texas. Graph generated from data in Tyler and others (1991). 


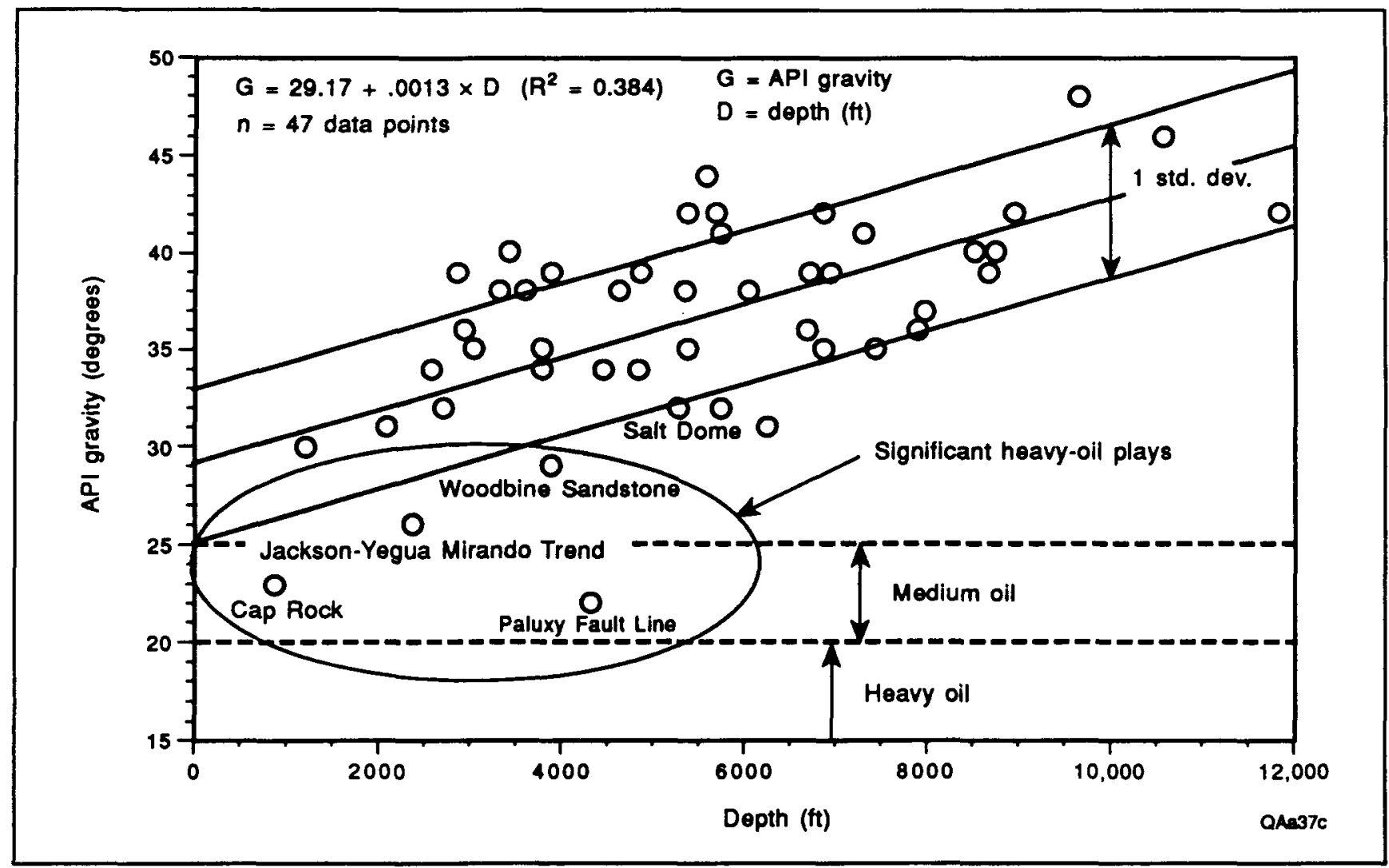

Figure 17. Graph of average API gravity versus average depth for all oil plays in Texas. Graph generated from data in Galloway and others (1983) and Tyler and others (1991).

depletion. The Woodbine Fluvial/Deltaic/Strandplain Sandstone play contains a single supergiant medium- to heavy-oil reservoir, Hawkins Woodbine. Oil gravity of individual wells within the Woodbine reservoir varies widely. Hawkins field produces from a faulted (individual faults are typically nonsealing) domal trap over a salt anticline in the East Texas Basin (Galloway and others, 1983). The base of the reservoirs is sealed by a 50 - to 100 -ft-thick (15- to $30-\mathrm{m}$ ) asphalt layer containing less than $12^{\circ}$ gravity hydrocarbons (King and Lee, 1976). The Piercement Salt Dome and Jackson-Yegua Barrier/ Strandplain Sandstone plays contain both heavy- and medium-gravity reservoirs. The greater average depth of the Piercement Salt Dome play results in the slightly higher average API gravity of this play. Medium gravity is characteristic of the shallow reservoirs in the Piercement Salt Domes. The Jackson-Yegua Barrier/Strandplain Sandstone play has the highest percentage of heavyand medium-gravity reservoirs of the large plays that include more than three reservoirs. The following section will discuss in greater detail the distribution of medium- and heavy-oil reservoirs in the Jackson-Yegua Barrier/Strandplain Sandstone play in South Texas.

\section{Medium- and Heavy-Oil Reservoirs in Jackson-Yegua Barrier/Strandplain Sandstones}

In the South Texas area (Bee, Duval, Jim Hogg, McMullen, Starr, Webb, and Zapata Counties), large oil reservoirs in the Jackson Group compose the JacksonYegua Barrier/Strandplain Sandstone play (Galloway and others, 1983), whereas both large and small JacksonYegua fields constitute the Mirando Trend (West, 1963) (fig. 15). For convenience, in this report the term large resenoirs refers only to reservoirs in the Jackson-Yegua Barrier/Strandplain Sandstone play, all of which have exceeded $10 \mathrm{MMbbl}\left(>1.6 \times 10^{6} \mathrm{~m}^{3}\right)$ cumulative production, and the term Mirando Trend refers to both the play and the continuum of fields in the trend.

Sandstone-rich sequences in the Jackson Group in South Texas are informally referred to as the Mirando, Loma Novia, Covernment Wells, and Cole sandstones. Although the Mirando Trend derived its name from 


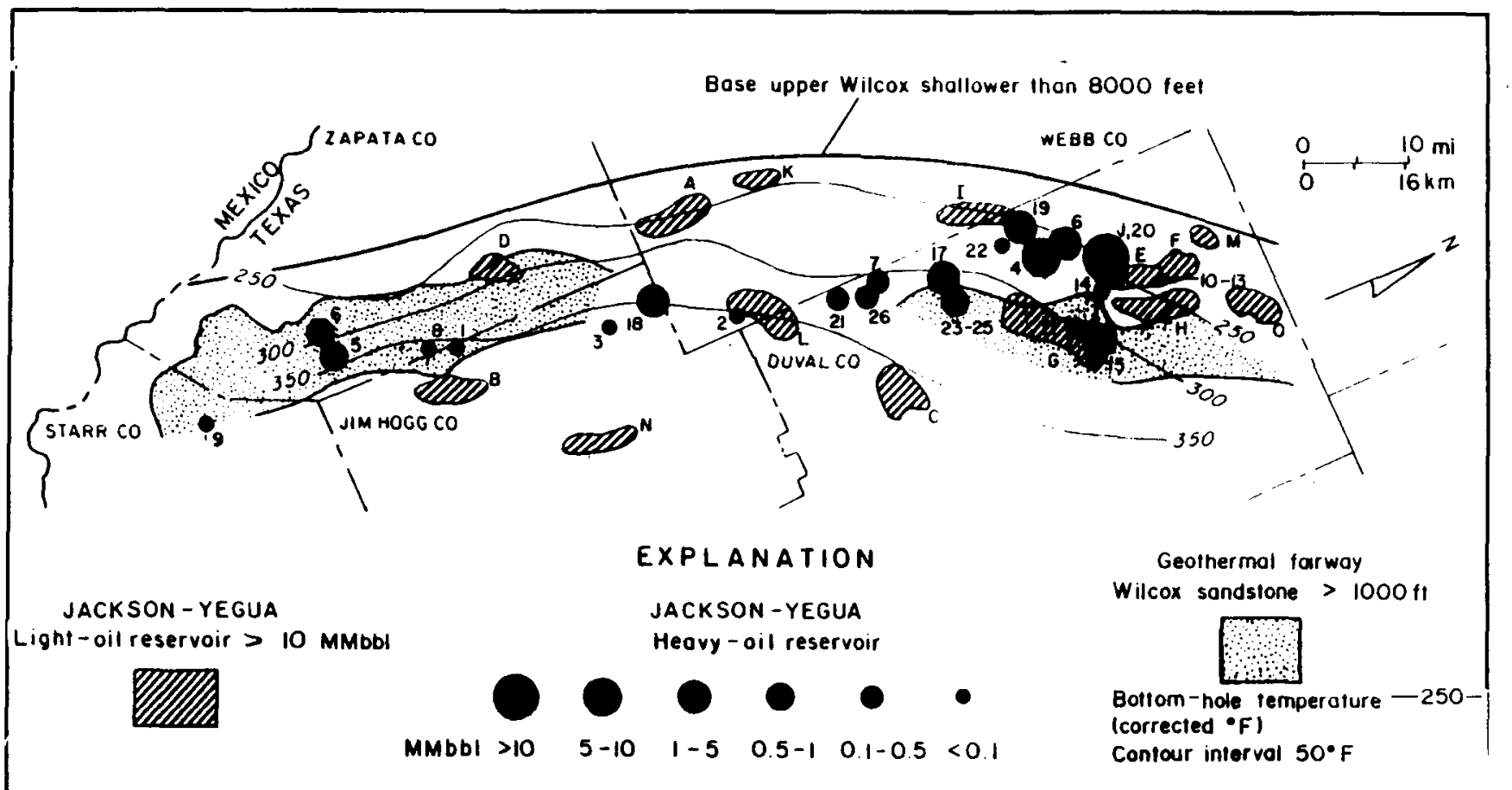

$0 \triangle 15238$

Figure 18. Map showing geopressured geothermal corridor of the deep upper Wilcox in South Texas (Gregory and others, 1980; Hamlin and others, 1989), the location of two geothermal fainways (stippled) aseociated with net sandstone in the upper Wilcox thicker than 1,000 $\mathrm{ft}(300 \mathrm{~m})$, the distribution of large oil reservoirs (Ewing, 1983), and the location of heavy-oil reservoirs within the geopreseured-geothermal corridor. Heavy-oil reservoin are represented by solid circles whose size is proportional to the size of the reservoir. Letters associated with each lange oil reservoir refer to reservoir names listed in appendix 1 . Numbers aseociated with each heavy-oil resenoir refer to reservoir names listed in appendix 1. Updip of the corridor, the base of the upper Wilcox is shallower than $8,000 \mathrm{ft}(<2,450 \mathrm{~m})$. The corridor includes the area downdip of the $250^{\circ} \mathrm{F}\left(121^{\circ} \mathrm{C}\right)$ isotherm in the upper Wilcox.

reservoirs in the Mirando sandstone, it includes reservoirs in all of the informally named jackson Group sandstones, as well as in Yegua sandstones such as the Pettus sandstone. The Covernment Wells and Cole sandstones lie within the upper Jackson, whereas the Loma Novia and Mirando sandstones are in the lower Jackson.

Two classes of oil reservoirs were analyzed in the Jackson Group in South Texas: (1) all large oil reservoirs (16) with cumulative production greater than $10 \mathrm{MMbbl}$ $\left(>1.6 \times 10^{6} \mathrm{~m}^{3}\right)$ that compose the Jackson-Yegua Barrier/ Strandplain Sandstone play (Galloway and others, 1983) and (2) all heavy-oil reservoirs (26) with API gravity less than or equal to $20^{\circ}$ that are colocated within the South Texas geothermal corridor (fig. 18; tables 5 and 6). In this report, the South Texas Wilcox geothermal corridor is defined by the area where the base of the upper Wilcox is deeper than $8,000 \mathrm{ft}(2,438 \mathrm{~m})$ (fig. 18). The corridor is downdip of the $250^{\circ} \mathrm{F}\left(121^{\circ} \mathrm{C}\right)$ temperature contour in the upper Wilcox and is associated with thick net sandstones in the deep upper Wilcox (Gregory and others, 1980; Hamlin and others, 1989) in the five-county area of Duval, Jim Hogg, Starr, Webb, and Zapata Counties. Well control and locations of cross sections are shown in figure 19.

\section{Large Reservoirs}

Our survey of large oil reservoirs within the JacksonYegua Barrier/Strandplain Sandstone play (Galloway and others, 1983; Tyler and others, 1991) includes those that have produced heavy- $\left(S 20^{\circ}\right)$, medium- $\left(>20^{\circ}\right.$ to $\left.25^{\circ}\right)$, and light- $\left(>25^{\circ}\right)$ gravity oil (table 5$)$. The large reservoirs have oil with an average API gravity of $25^{\circ}$. One additional field and reservoir — Lundell (Cole)—was added to the play compilation because it achieved cumulative production greater than $10 \mathrm{MMbbl}\left(>1.6 \times 10^{6} \mathrm{~m}^{3}\right)$. Not all of the large oil reservoirs lie within the geothermal 
Table 5. Characteristics of large oil reservoirs.

\begin{tabular}{|c|c|c|c|}
\hline $\begin{array}{c}\text { RRC } \\
\text { district }\end{array}$ & Field and reservoir & $\begin{array}{l}\text { Discovery } \\
\text { date }\end{array}$ & Lithology \\
\hline 4 & Aviators, Mirando & 1922 & Sandstone \\
\hline 4 & Colorado, Cockfield & 1936 & Sandstone \\
\hline 4 & Conoco Driscoll & 1937 & Sandstone \\
\hline 4 & Escobas, Mirando & 1928 & Sandstone \\
\hline 4 & Govt. Wells $N$ & 1928 & Sandstone \\
\hline 4 & Govt. Wells S & 1928 & Sandstone \\
\hline 4 & Hoffman, Dougherty & 1947 & Sandstone \\
\hline 4 & Loma Novia, Loma Novia & 1935 & Sandstone \\
\hline 4 & Lopez, First Mirando & 1935 & Sandstone \\
\hline 4 & Lundell & 1937 & Sandstone \\
\hline 4 & Mirando City, Mirando & 1921 & Sandstone \\
\hline 4 & O'Hem, Petus & 1930 & Sandstone \\
\hline 4 & Piedre Lumbre & 1935 & Sandstone \\
\hline 4 & Prado Middle, Loma Novia & 1956 & Sandstone \\
\hline 4 & Seven Sisters & 1935 & Sandstone \\
\hline
\end{tabular}

$\begin{array}{lcccccc}\text { Trap* } & \text { Drivet } & \begin{array}{c}\text { Depth } \\ \text { (ft) }\end{array} & \begin{array}{c}\text { Oil } \\ \text { column } \\ \text { (ft) }\end{array} & \begin{array}{c}\text { Pororsity } \\ (\boldsymbol{\%})\end{array} & \begin{array}{c}\text { Permeability } \\ \text { Average } \\ \text { (md) }\end{array} & \begin{array}{c}\text { Log } \\ \text { range }\end{array} \\ \text { UPP } & \text { SG + WD } & 1,700 & 51 & 32 & 357 & 1-3 \\ \text { UPP } & \text { SG } & 2,600 & 300 & 28 & 800 & 2-3 \\ \text { NPP } & \text { GCE } & 2,800 & 54 & 31 & 458 & - \\ \text { NPP } & \text { SG } & 1,200 & 70 & 30 & 500 & 1-3 \\ \text { UPP } & \text { SG + WD } & 2,200 & 60 & 32 & 800 & 2-3 \\ \text { UPP } & \text { SG } & 2,300 & 89 & 30 & 600 & 2-3 \\ \text { NPP } & \text { SG } & 2,000 & 250 & 34 & 757 & - \\ \text { UPP } & \text { SG } & 2,600 & 240 & 26 & 800 & 1-3 \\ \text { UPP } & \text { Combined } & 2,200 & 70 & 35 & 250 & 1-3 \\ \text { UPP } & \text { SG } & 1,528 & 10 & -3 & -1 & - \\ \text { UPP } & \text { Combined } & 1,600 & 35 & 33 & 1,600 & 2-3 \\ \text { NPP } & \text { SG } & 2,700 & 200 & 28 & 286 & 1-3 \\ \text { NPP } & \text { WD + SG } & 1,900 & 65 & 30 & 300 & 1-3 \\ \text { UPP } & \text { SG + GCE } & 3,700 & 65 & 32 & 850 & 1-4 \\ \text { NPP } & \text { SG + WD } & 2,330 & 75 & 28 & 225 & 1-2 \\ & & & & & & \end{array}$

నั

\begin{tabular}{|c|c|c|c|}
\hline $\begin{array}{l}\text { RRC } \\
\text { diastrict }\end{array}$ & Field and reservoir & $\begin{array}{l}\text { Initial } \\
\text { presoure }\end{array}$ & $\begin{array}{c}\text { Temperature } \\
\text { (F) }\end{array}$ \\
\hline 4 & Aviators, Mirando & 700 & 107 \\
\hline 4 & Colorado, Cockfield & 1,125 & 145 \\
\hline 4 & Conoco Driscoll & 1,290 & 153 \\
\hline 4 & Escobas, Mirando & 575 & 100 \\
\hline 4 & Govt. Wells N & 875 & 114 \\
\hline 4 & Gont. Wells S & 850 & - \\
\hline 4 & Hoffman, Dougherty & 795 & 131 \\
\hline 4 & Loma Novia, Loma Novia & 1,003 & 114 \\
\hline 4 & Lopez, First Mirando & 780 & 111 \\
\hline 4 & Lundell & 700 & - \\
\hline 4 & Mirando City, Mirando & 665 & - \\
\hline 4 & O'Hern, Pettus & 990 & 136 \\
\hline 4 & Piedre Lumbre & 820 & 100 \\
\hline 4 & Prado Middle, Loma Novia & 1,407 & 109 \\
\hline \multirow[t]{2}{*}{ 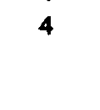 } & Seven Sisters & $\underline{1,150}$ & 132 \\
\hline & $\begin{array}{l}15 \text { helds, } 15 \text { reservours } \\
\text { Mean }\end{array}$ & 915 & 121 \\
\hline
\end{tabular}

Table 5 (cont.)

\begin{tabular}{|c|c|c|c|c|c|c|c|}
\hline $\begin{array}{l}\text { Production } \\
\text { tecturologr" }\end{array}$ & $\begin{array}{l}\text { Uniti- } \\
\text { zation } \\
\text { dace }\end{array}$ & $\begin{array}{c}\text { Well } \\
\text { spacing } \\
\text { (acres) }\end{array}$ & $\begin{array}{l}\text { Residual oil } \\
\text { saturation } \\
\text { (\%) }\end{array}$ & $\begin{array}{c}\text { Oil } \\
\text { in place } \\
\text { (MMbb) }\end{array}$ & $\begin{array}{l}\text { Cumulative } \\
\text { production } \\
\text { (Mubb) }\end{array}$ & $\begin{array}{l}\text { Ultimate } \\
\text { recovery } \\
\text { (MMbb) }\end{array}$ & $\begin{array}{c}\text { Recovery } \\
\text { efficiency } \\
\left(\chi_{0}\right)\end{array}$ \\
\hline WF & 1966 & 10 & 25 & 37 & 10.1 & 10.3 & 28 \\
\hline WF & - & $10-40$ & 31 & 52 & 21.7 & 21.8 & 42 \\
\hline PMG & 1937 & 20 & 9 & 69 & 20.0 & 23.7 & 34 \\
\hline$W F, T$ & - & 10 & 30 & 28 & 12.8 & 12.9 & 46 \\
\hline WF, P, T & - & 10 & 36 & 150 & 77.3 & 78.0 & 52 \\
\hline PMG, WF & - & 10 & 20 & 40 & 16.6 & 18.0 & 45 \\
\hline WF, P & - & 16 & 18 & 55 & 20.5 & 21.0 & 38 \\
\hline WF, PMG & - & 10 & 35 & 176 & 47.7 & 48.0 & 27 \\
\hline PMG, WF, T & 1955 & 10 & 25 & 75 & 30.4 & 33.0 & 44 \\
\hline WF & - & - & - & - & 10.4 & - & - \\
\hline WF, T & - & - & 25 & 46 & 12.1 & 12.1 & 26 \\
\hline PMG, WF, T & 1957 & 10 & 20 & 83 & 22.2 & 30.0 & 36 \\
\hline PMG, WF, LPG & - & 10 & 25 & 95 & 20.7 & 22.0 & 23 \\
\hline PMG, WF & 1957 & 10 & 30 & 38 & 10.4 & 23.7 & 62 \\
\hline \multirow[t]{2}{*}{ PMG, WF } & - & 10 & 15 & 142 & $\underline{35.0}$ & $\underline{56.0}$ & $\underline{39}$ \\
\hline & & & 25 & 1086 & 3679 & $A d 05$ & 39 \\
\hline
\end{tabular}


Table 6. Characteristics of heavy-oil reservoirs.

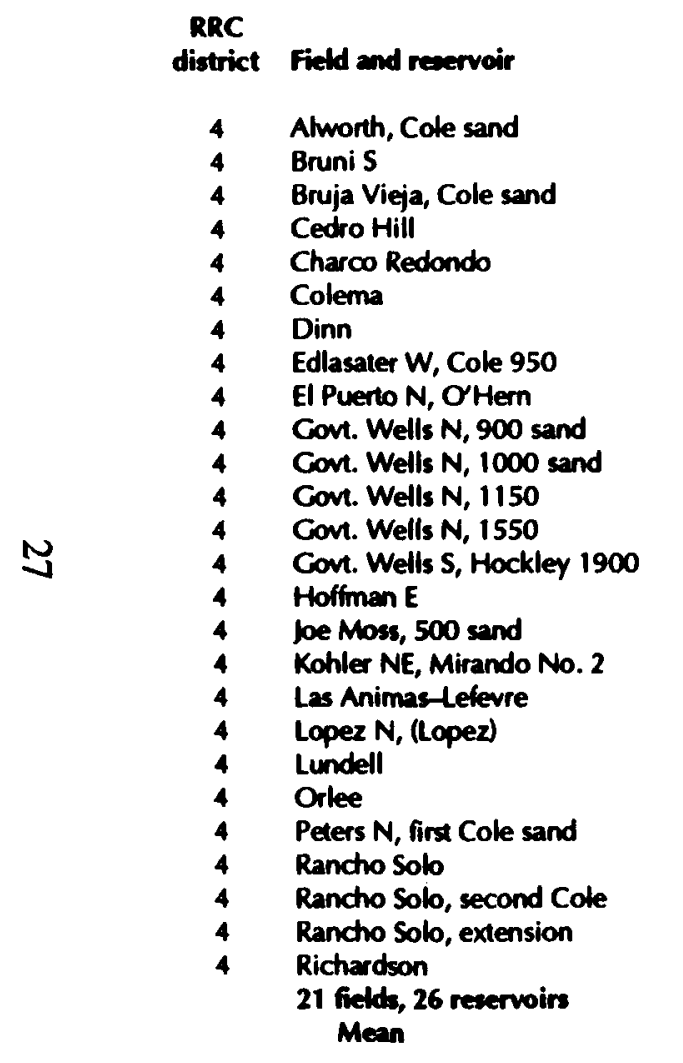

$\begin{array}{ccc}\begin{array}{c}\text { Diacovery } \\ \text { date }\end{array} & \text { Lithology } & \text { Trap* } \\ 1965 & \text { Sandstone } & \text { NPP } \\ 1944 & \text { Sandstone } & \text { UPP } \\ 1950 & \text { Sandstone } & \text { UPP } \\ 1938 & \text { Sandstone } & \text { UPP } \\ 1913 & \text { Sandstone } & \text { UPP } \\ 1936 & \text { Sandstone } & \text { UPP } \\ 1949 & \text { Sandstone } & \text { UPP } \\ 1968 & \text { Sandstone } & \text { UPP } \\ 1965 & \text { Sandstone } & \text { NPP } \\ 1948 & \text { Sandstone } & \text { UPP } \\ 1950 & \text { Sandstone } & \text { UPP } \\ 1978 & \text { Sandstone } & \text { UPP } \\ 1949 & \text { Sandstone } & \text { UPP } \\ 1965 & \text { Sandstone } & \text { UPP } \\ 1950 & \text { Sandstone } & \text { UPP } \\ 1952 & \text { Sandstone } & \text { UPP } \\ 1980 & \text { Sandstone } & \text { SSF } \\ 1937 & \text { Sandstone } & \text { UPP } \\ 1951 & \text { Sandstone } & \text { UPP } \\ 1937 & \text { Sandstone } & \text { UPP } \\ 1949 & \text { Sandstone } & \text { NPP } \\ 1959 & \text { Sandstone } & \text { SSF } \\ 1937 & \text { Sandstone } & \text { SSF } \\ 1959 & \text { Sandstone } & \text { UPP } \\ 1939 & \text { Sandstone } & \text { UPP } \\ 1944 & \text { Sandstone } & \text { UPP } \\ & & \\ & & \end{array}$

Oit

$\begin{array}{crcc}\text { Drivet } & \begin{array}{c}\text { Depth } \\ \text { (ft) }\end{array} & \begin{array}{c}\text { Oil } \\ \text { colum } \\ \text { (ft) }\end{array} & \begin{array}{c}\text { Porosity } \\ \text { (\%) }\end{array} \\ \text { WD } & 1,040 & 6 & 29 \\ - & 1,804 & - & 31 \\ \text { - WD } & 1,755 & - & - \\ \text { SG + } & 1,440 & 12 & 31 \\ \text { SG } & 339 & 14 & 33 \\ \text { SG + WD } & 1,500 & 20 & 32 \\ \text { WD } & 1,805 & 5 & - \\ - & 950 & - & - \\ - & 760 & - & - \\ - & 918 & - & - \\ - & 1,062 & - & - \\ - & 1,167 & - & - \\ - & 1,547 & - & - \\ \overline{\text { SG }} & 1,919 & - & - \\ - & 2,038 & 20 & - \\ \text { SG } & 2,633 & - & - \\ \text { SG } & 1,793 & 20 & - \\ \text { SG } & 2,064 & 10 & 31 \\ \text { SG } & 1,528 & 10 & - \\ \text { WD } & 1,697 & 10 & 25 \\ - & 1,746 & - & - \\ - & 1,849 & - & - \\ - & 1,840 & - & 31 \\ - & 1,836 & - & - \\ - & 1,784 & = & = \\ & 1,512 & 12.7 & 31\end{array}$

Permeability

$\begin{array}{ccccc}\text { Average } & \text { Log } & \text { Water } & \text { API } & \text { Initial } \\ \text { (mol) } & \text { range } & \text { saturation } & \text { gravity } & \text { pressure }\end{array}$

$\begin{array}{rr}511 & - \\ 600 & - \\ 700 & - \\ 1.659 & 1-2 \\ 650 & - \\ - & - \\ - & - \\ - & - \\ - & - \\ = & - \\ - & - \\ - & - \\ = & - \\ \overline{-} & - \\ 428 & - \\ 200 & - \\ - & - \\ - & - \\ - & - \\ = & = \\ & =\end{array}$

191

30

600

-

-

-

$-$

$-$

-

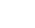

-

960

700
765

765

-

$\overline{-}$

533

-Types of trap are the following: NPP = porosity pinch-out across a nose (dome, terrace); SSF = simple sealing fault; and UPP = updip porosity pinch-out.

tTypes of drive are the following: SG = solution-gas drive (depletion, fluid expansion, etc.) and WD = water drive.

$\neq T$ ypes of production technology are the following: $T=$ thermal recovery project and $W F=$ waterflood.

Dashes indicate information is not available. 
Table 6 (cont.)

\begin{tabular}{|c|c|c|c|c|c|c|}
\hline $\begin{array}{c}\text { RRC } \\
\text { district }\end{array}$ & Field and reservoir & $\begin{array}{l}\text { Production } \\
\text { technology }\end{array}$ & $\begin{array}{l}\text { Well } \\
\text { spacing } \\
\text { (acres) }\end{array}$ & $\begin{array}{l}\text { Residual oil } \\
\text { saturation } \\
\left(\%_{0}\right)\end{array}$ & $\begin{array}{l}\text { Cumulative } \\
\text { production } \\
\text { (MMbb) }\end{array}$ & $\begin{array}{l}\text { P1. ducing } \\
\text { sandstone }\end{array}$ \\
\hline 4 & Alworth, Cole sand & WF & 63 & - & .078 & Cole \\
\hline 4 & Brunis & - & - & - & .001 & Cole \\
\hline 4 & Bruja Vieja, Cole sand & - & - & - & .001 & Cole \\
\hline 4 & Cedro Hill & WF & - & 13.65 & 6.569 & Cole \\
\hline 4 & Charco Redondo & $\mathbf{T}$ & - & 7.7 & .659 & Cole \\
\hline 4 & Colema & WF & - & - & 3.868 & Cole \\
\hline 4 & Dinn & - & - & - & .319 & Cole \\
\hline 4 & Edlasater W, Cole 950 & - & - & - & .013 & Cole \\
\hline 4 & El Puerto N, O'Hem & - & - & - & .001 & Fourth Mirando \\
\hline 4 & Covt. Wells $N, 900$ sand & - & - & - & .315 & Cole \\
\hline 4 & Covt. Wells $N, 1000$ sand & - & - & - & .080 & Cole \\
\hline$N$ & Govt. Wells N, 1150 & - & - & - & .023 & Cole \\
\hline 4 & Cont. Wells N, 1550 & - & - & - & .030 & Cole \\
\hline 4 & Govt. Wells S, Hockley 1900 & - & - & - & .030 & Taracahuas \\
\hline 4 & Hoffman E & - & - & - & 1.387 & Taracahuas \\
\hline 4 & joe Moss, 500 sand & - & - & - & .557 & Second Mirando \\
\hline 4 & Kohler NE, Mirando No. 2 & - & - & - & 1.217 & Cole \\
\hline 4 & Las Animas-Lefevre & - & - & - & 3.402 & Cole \\
\hline 4 & Lopez N (Lopez) & WF & - & 3.600 & 2.225 & Cole \\
\hline 4 & Lundell & WF & - & - & 10.358 & Cole \\
\hline 4 & Orlee & WF & - & - & .266 & First Cole \\
\hline 4 & Peters N, first Cole sand & - & - & - & .042 & Cole \\
\hline 4 & & - & - & - & .465 & First Cole \\
\hline 4 & Rancho Solo, second Cole & - & - & - & .030 & Second Cole \\
\hline 4 & Rancho Solo, extension & - & - & - & .520 & Cole \\
\hline 4 & Richardson & - & - & - & .147 & Cole \\
\hline & $\begin{array}{l}21 \text { fields, } 26 \text { reservoirs } \\
\text { Sum }\end{array}$ & & & & 32.92 & \\
\hline
\end{tabular}

-Types of trap are the following: NPP = porosity pinch-oul across a nose (dome, terrace); SSF = simple sealing fault; and UPP = updip porosity pinch-out.

tTypes of drive are the following: SG = solution-gas drive (depletion, fluid expansion, etc.) and WD = water drive.

\#Types of production technology are the following: $T=$ thermal recovery project and $W F=$ waterflood.

Dashes indicate information is not available. 


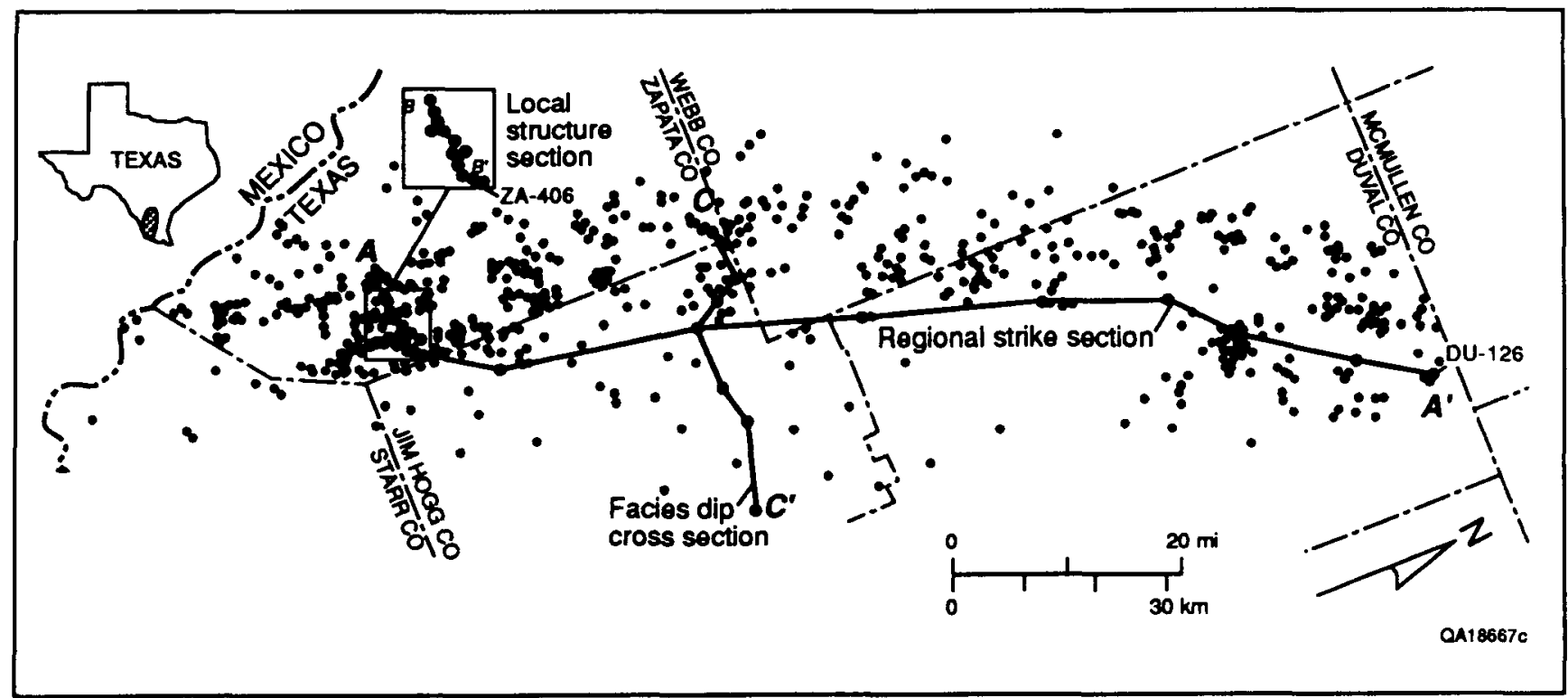

Figure 19. Map locating well control and cross sections. Names of wells on cross sections are listed in appendix 2.

corridor. Original oil in place of the large reservoirs in the Jackson-Yegua Barrier/Strandplain Sandstone play alone is $1.1 \mathrm{Bbbl}\left(1.7 \times 10^{8} \mathrm{~m}^{3}\right.$ ) (Galloway and others, 1983), and cumulative production is $448 \mathrm{MMbbl}$ $\left(7.1 \times 10^{7} \mathrm{~m}^{3}\right)$ (Tyler and others, 1991). Recovery efficiency using primary and secondary recovery for the large reservoirs is a relatively low 37 percent (Galloway and others, 1983). The large reservoirs in the trend (Government Wells-cumulative production $80.0 \mathrm{MMbbl}\left[1.3 \times 10^{7} \mathrm{~m}^{3}\right]$ through 1990 and Loma Novia-cumulative production $48.6 \mathrm{MMbbl}$ $\left[7.7 \times 10^{6} \mathrm{~m}^{3}\right]$ through 1990$)$ produce medium-gravity oil. Two of the large reservoirs, Lundell and Seven Sisters, produce heavy oil; eight of the large reservoirs produce medium oil. Heavy-oil reservoirs represent 15 percent and medium-oil reservoirs 53 percent of the cumulative production of the large reservoirs in the Mirando Trend in the five-county area. Oil gravity may be quite variable within a given field or resenvoir. For example, in the largest field in the Mirando Trend, Covernment Wells North, 20 separate reservoirs produce from Jackson and Yegua sandstones. Oil gravity ranges from $19^{\circ}$ to $35.1^{\circ}$ (mean gravity $=24.64^{\circ} ;$ standard deviation $=5.13^{\circ}$ ) over a depth range of 918 to $3,264 \mathrm{ft}(280$ to $995 \mathrm{~m})$, a mean depth of $1,855 \mathrm{ft}(565 \mathrm{~m})$, and a standard deviation of $646 \mathrm{ft}(197 \mathrm{~m})$.

\section{Heavy-Oil Reservoirs}

In the South Texas geothermal corridor, 21 heavy-oil fields (26 reservoirs) have a minimum cumulative pro- duction of $1,000 \mathrm{bbl}\left(159 \mathrm{~m}^{3}\right)$ per reservoir (table 6). This corridor covers a small area of the Mirando Trend, and thus many heavy-oil reservoirs lie outside the geothermal corridor boundary. The heavy-oil reservoirs compose a resource target with original oil in place of 110 to $330 \mathrm{MMbbl}\left(1.7 \times 10^{7}\right.$ to $\left.5.2 \times 10^{7} \mathrm{~m}^{3}\right)$ over the South Texas geothermal corridor (fig. 15). Recovery efficiency of the heavy-oil reservoirs is estimated at 10 to 30 percent (Charles Kimmell, Fanion Production Company, personal communication, 1990). Total cumulative production from the heavy-oil fields in the South Texas geothermal corridor is $32.9 \mathrm{MMbbl}$ $\left(5.2 \times 10^{6} \mathrm{~m}^{3}\right)$. Seven Sisters (first Cole), the largest heavyoil field, had a cumulative production of $56.0 \mathrm{mmbbl}$ $\left(8.9 \times 10^{6} \mathrm{~m}^{3}\right)$ through 1988; however, it is located just updip of the geothermal corridor. Lundell, the largest heavy-oil reservoir within the geothermal corridor, had a cumulative production of $10.4 \mathrm{MMbbl}\left(1.65 \times 10^{6} \mathrm{~m}^{3}\right)$ through 1988.

\section{API Gravity and Depth}

A plot of API gravity versus depth illustrates an important correlation of API gravity with depth of the large and heavy-oil reservoirs (fig. 20) of the Mirando Trend. The large oil reservoirs show two trends of API gravity with depth: (1) a shallow trend of relatively consistent API gravity (average API gravity $=21^{\circ}$ ) over a depth range of 1,000 to $2,500 \mathrm{ft}$ (305 to $762 \mathrm{~m}$ ) and (2) a deep trend of increasing API gravity with increasing 


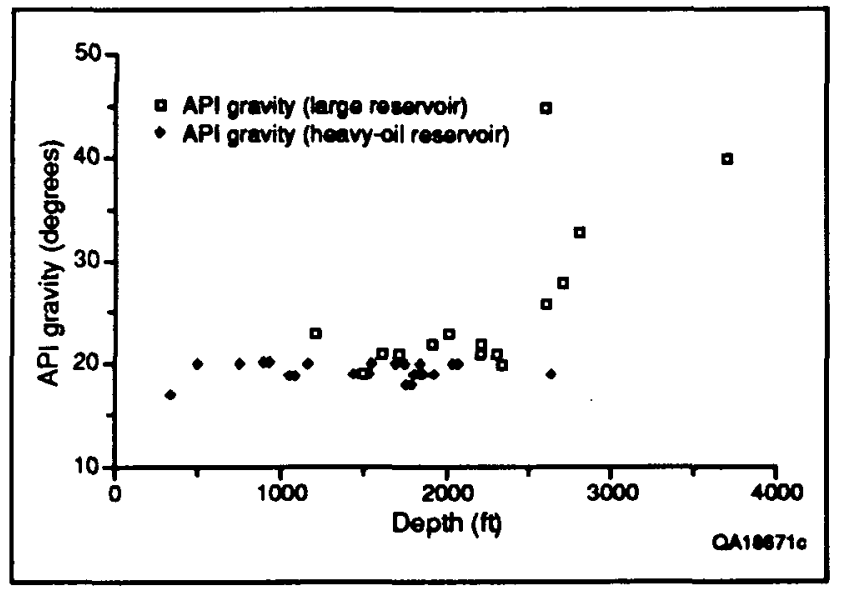

Figure 20. Plot of API gravity as a function of depth for two types of Jackson Group reservoirs in South Texa: large reservoirs and heavy-oil reservoirs. Large reservoirs tend to be deeper and have a greater API gravity value (less viscous) than heavy-oil reservoirs.

depth over a depth range of 2,500 to $4,000 \mathrm{ft}$ (762 to $1,219 \mathrm{~m})$. The heavy-oil resenoirs show a relatively constant gravity (average API gravity $=19.3^{\circ}$ ) over a depth range of 200 to $2,500 \mathrm{ft}(61$ to $762 \mathrm{~m}$ ). Heavy-oil reservoirs are much shallower than the large reservoirs (mean depth of $1,512 \mathrm{ft}[461 \mathrm{~m}]$ for heavy reservoirs versus $2,273 \mathrm{ft}[693 \mathrm{~m}$ ] for large reservoirs). The overall trend of API gravity for both populations of reservoirs illustrates relatively constant gravity (average API gravity $=20^{\circ}$ ) for reservoirs at a depth of 200 to $2,500 \mathrm{ft}$ $(61$ to $762 \mathrm{~m})$. The gravity trend then increases linearly for reservoirs at greater depths.

The rapid increase in API gravity at depths greater than 2,500 $\mathrm{ft}(>762 \mathrm{~m})$ indicates API gravity is controlled by depth-related processes. Two possibly interrelated processes may be responsible for this increase: (1) a depth-related increase in temperature, which limits activity of oil-degrading bacteria at about $2,500 \mathrm{ft}$ $(\sim 762 \mathrm{~m})$ and (2) fresh-water invasion, which is limited to the section shallower than $2,500 \mathrm{ft}(<762 \mathrm{~m})$. The consistently low API gravity for the shallow reservoirs is interpreted as resulting from water washing and bacterial degradation that was particularly active above a depth of 2,500 ft (>762 m) (Tissot and Welte, 1984). In the South Texas area, the corrected subsurface temperature would be $119^{\circ} \mathrm{F}\left(48^{\circ} \mathrm{C}\right)$ at $2,500 \mathrm{ft}(762 \mathrm{~m})$ (fig. 6). Fresh-water invasion in Jackson Group sandstones is indicated by electric logs that show reversal (positive deflection) of the SP curve to a depth of at least 2,000 ft $(610 \mathrm{~m})$. The processes that result in formation of low API gravity crude oils include biodegradation, water washing, loss of volatiles, and oxidation (Philippi, 1977;
Tissot and Welte, 1984). Deeper than 2,500 ft (>762 m), the API gravity increases with depth as a function of increasing temperature above $119^{\circ} \mathrm{F}\left(>48^{\circ} \mathrm{C}\right)$, absence of meteoric water, and less biodegradation.

The API gravity of oil in South Texas Mirando Trend reservoirs also reveals a stratigraphic and geographic segregation among the various Jackson Group sand bodies (fig. 21). The Mirando Trend includes reservoirs within the upper Jackson Group Cole and Government Wells sandstones and the lower Jackson Group Loma Novia and Mirando sandstones, as well as within the Yegua Formation Pettus sandstone. Seventy-nine percent of the oil in the largest reservoirs is in the Covernment Wells and Mirando sands, and the largest reservoirs contain predominantly medium-gravity oil. In contrast, 84 percent of the heavy oil is in Cole sands. The Cole sands contain no medium-oil reservoirs that have a cumulative production greater than $10 \mathrm{MMbbl}\left(>1.6 \times 10^{6} \mathrm{~m}^{3}\right)$. The shallow Cole sands contain many small heavy-oil reservoirs, whereas the medium-oil resenoirs in the Mirando and Government Wells sands are much larger.

\section{Discussion}

The greatest concentration of medium- and heavyoil reservoirs lies along the Texas Gulf Coast in the (1) Jackson-Yegua Barrier/Strandplain Sandstone, (2) Cap Rock, and (3) Piercement Salt Dome plays. Many medium-oil reservoirs also lie in the Frio Barrier/Strandplain Sandstone play along the central Texas Gulf Coast. The East Texas Basin also contains a few large medium- and heavy-oil reservoirs in two plays, the Paluxy Fault Line and the Woodbine Fluvial/ Deltaic/Strandplain plays. The Gulf Coast region in Texas is most favorable for juxtaposition of oil plays containing large medium- to heavy-oil reservoirs and geothermal corridors. The Jackson-Yegua Barrier/Strandplain Sandstone play (Mirando Trend) is the most favorable play for thermal development of medium- to heavy-oil reservoirs because of the abundance, the large size, and the shallow depth of reservoirs.

The general trend of decreasing API gravity (increasing viscosity) with decreasing depth is attributed to degradation of oil quality through oxidization by contact with meteoric waters and biodegradation by aerobic bacteria (Tissot and Welte, 1984; North, 1985). According to Tissot and Welte (1984), most heavy oils originate from normal, light crude oils that have been subsequently degraded in the reservoir by one or more processes, including biodegradation, water washing, loss of volatiles, and inorganic oxidation. As a result, the percentage of light fractions in the crude oil decreases and the 


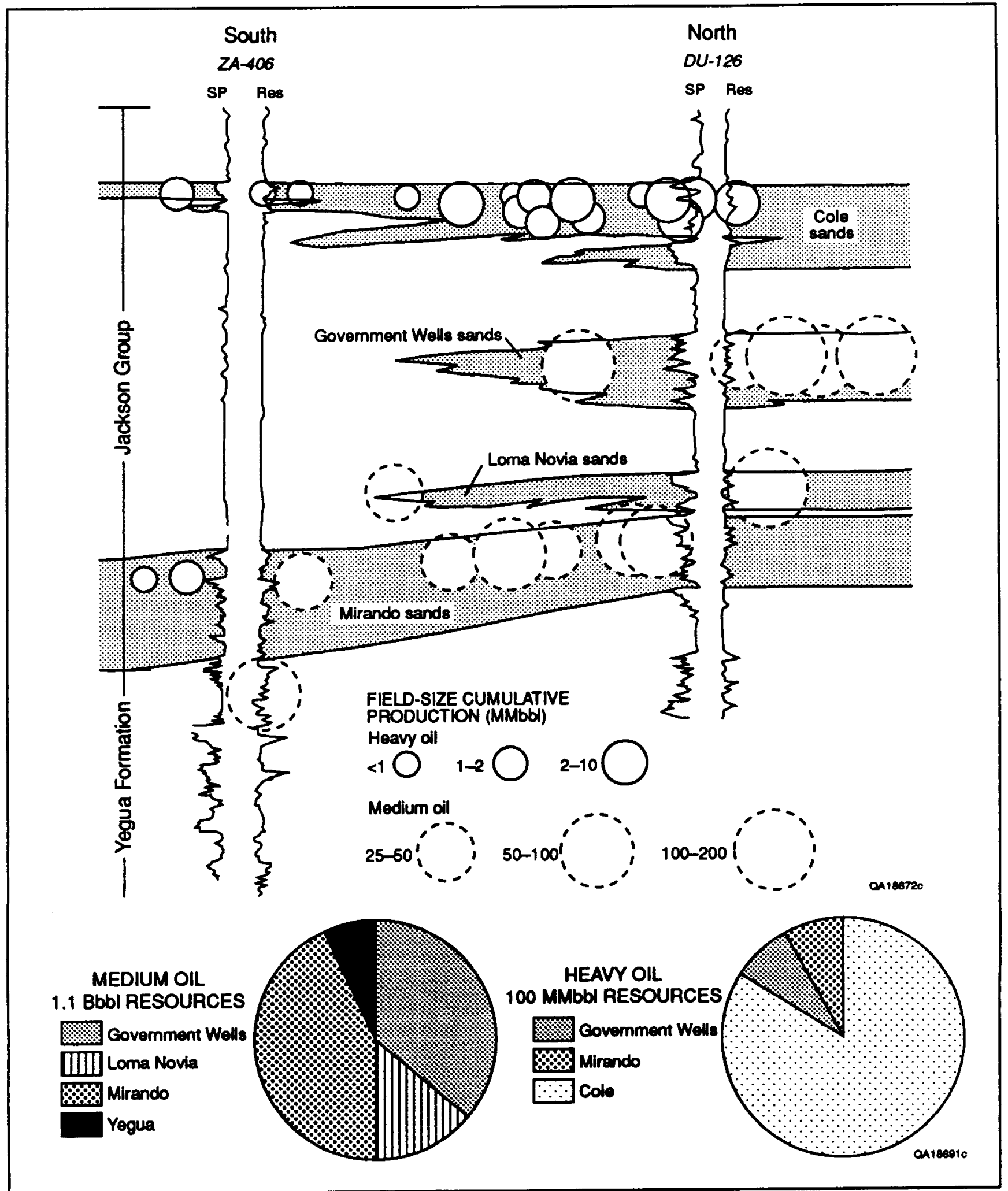

Figure 21. Croes section A-A' along strike from Zapata County (couth) to Duval County (north) illustrating stratigraphic and lateral distribution of heavy-oil reservoirs (API $S 0^{\circ}$ ) and large reservoirs in the Jackeon Group (from Galloway and others, 1983). Pie diagrams show segregation of reservoirs within stratigraphic horizons. Heavy-oil reservoirs are concentrated in Cole sands, whereas large reservoin are concentrated in Govemment Wells, Loma Novia, and Mirando sands. Wells are located at southem and northem ends of regional strike section (figure 19). Well names are listed in appendix 2. 
percentage of more resistant heavier fractions, including the asphaltenes, increases. The extent of degradation is associated with depth, proximity to meteoric waters, and salinity of formation waters. The medium- and heavy-oil reservoirs in Texas are excellent examples of degradation through these processes. In contrast to the dominant trend of decreasing API gravity with decreasing depth in Texas, some basins, such as Greater Oficina area in Venezuela and the Baku region of the Caspian Sea, exhibit the opposite trend of decreasing API gravities with increasing depth as a result of density stratification and increases in water salinity with depth (North, 1985).

Although medium- and heavy-oil reservoirs constitute 10 percent of the large oil reservoirs in Texas, their cumulative production represents only 8.4 percent of the production from the large oil reservoirs. The 1.6 percent difference is a result of the lower average productivity of the medium- and heavy-oil reservoirs and is equivalent to a difference of $629 \mathrm{MMbbl}$ $\left(1.0 \times 10^{8} \mathrm{~m}^{3}\right)$ (or 1.6 percent $\times$ total cumulative production of large reservoirs in Texas) in production between light- and medium- to heavy-oil reservoirs. This is one measure of the potential size of the resource target that is available for geothermally enhanced recovery.

Tyler and others (1984) used the plays delineated by Galloway and others (1983) to evaluate targets for additional recovery of oil in Texas. For the JacksonYegua Barrier/Strandplain Sandstone play alone, they calculated $249 \mathrm{MMbbl}\left(4.0 \times 10^{7} \mathrm{~m}^{3}\right)$ of potentially recoverable target oil. Tyler and others (1984) based their calculation on $1.13 \mathrm{Bbbl}\left(1.8 \times 10^{8} \mathrm{~m}^{3}\right)$ original oil in place, 62 percent unrecovered oil, 27 percent residual oil saturation, 33 percent water saturation (target oil $=$ [percentage of unrecovered oil-tresidual oil saturation/1-water saturation)] $\times$ original oil in place).

\section{Jackson Group Sand-Body Geometry, Facies, and Diagenesis}

Previous regional studies documented the sheetlike geometry and strike orientation of barrier bar/strandplain sands in the Jackson Group of South Texas (West, 1963; Fisher and others, 1970; Kaiser and others, 1978, 1980) and characterized specific oil fields and reservoirs (Galloway and others, 1983; Hopf, 1986; Schultz, 1986; Hyatt, 1990). Our analysis of Jackson Group sand-body geometry and depositional facies in the five-county study area supports previous interpretations of the dominance of shoreline barrier bar/strandplain facies in South Texas. Although the regional architecture of Jackson Group sandstones in the Mirando Trend is relatively simple, reservoir-scale architecture is complex in terms of sandbody geometries, depositional facies, and diagenesis. These complexities must be understood because they affect the suitability of Jackson Group sandstone reservoirs for a TEOR program.

\section{Sand-Body Geometry}

The Jackson Group in South Texas forms a sand-rich belt, 20 to $25 \mathrm{mi}$ ( 32 to $40 \mathrm{~km}$ ) wide, bounded by mudstone both updip and downdip (fig. 22). A diporiented cross section of the Jackson Group in Zapata County illustrates the typical structural setting and stratigraphic relationships of the Jackson Group across the deep Wilcox geothermal fairway and the association of oil reservoirs with the updip pinch-out of strikeelongate sandstones (fig. 23). The influence of faulting on regional patterns of hydrocarbon entrapment is relatively insignificant. However, small faults do form barriers to lateral migration in individual reservoirs. The gulfward dip of Jackson strata ranges from 125 to $250 \mathrm{ft} / \mathrm{mi}\left(1.4^{\circ}\right.$ to $\left.2.7^{\circ}\right)$ and has enhanced the gravity segregation and updip migration of hydrocarbons toward updip sandstone pinch-outs.

A strike-oriented cross section from Zapata to Duval Counties illustrates the lateral continuity of sandstones in the Jackson Group of the South Texas study area (fig. 24). To the north in Duval County, the Jackson is sand rich where Loma Novia and Government Wells sandstones are thick. The Mirando and upper Cole sandstones are continuous across the area; however, the Loma Novia, Government Wells, and lower Cole sandstones pinch out to the south. The axis of thickest 


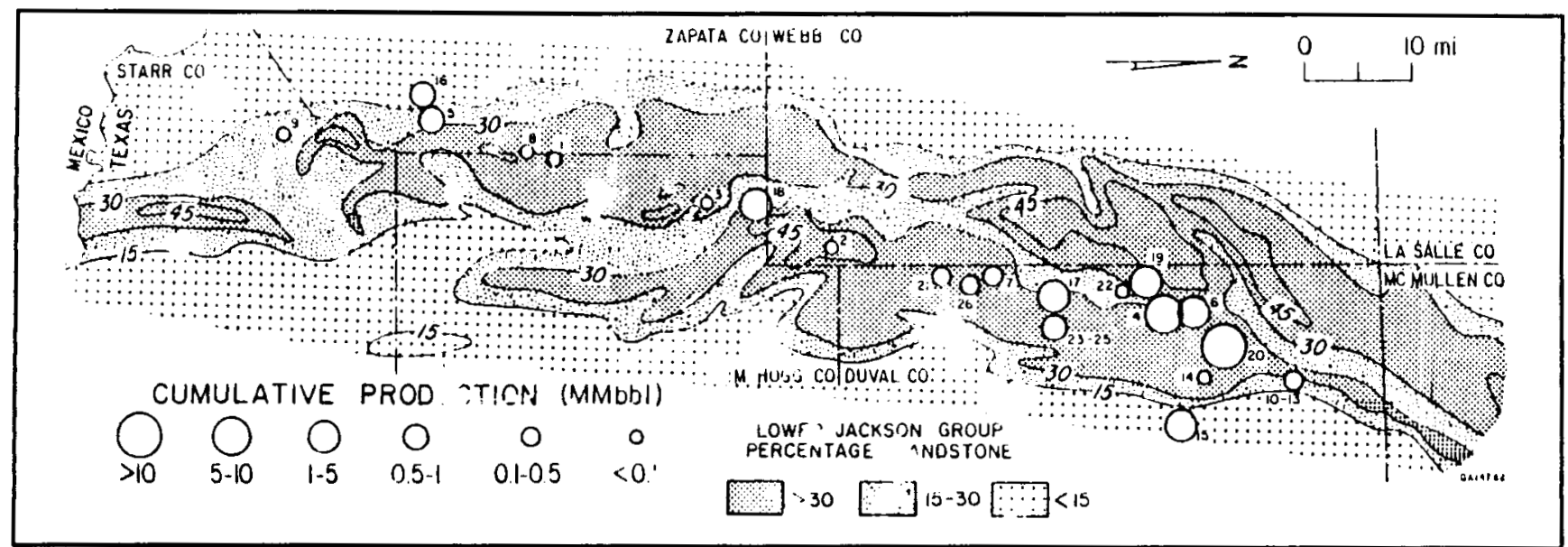

Figure 22. Percentage-sandstone map of the lower part of Jackon Group in South Texas (modified from Kaiser and others, 1980). The percentage of sand for the lower part of the Jackeon Croup does not control the location of heavy-oil reservoirs, which preferentially occur within the Cole sand in the upper part of the Jackeon Croup. The percentagesandstone map emphasizes the distribution of Mirando sands. Numbers acsociated with each heavy-oil reservoir correspond to reservoir names listed in appendix 1.

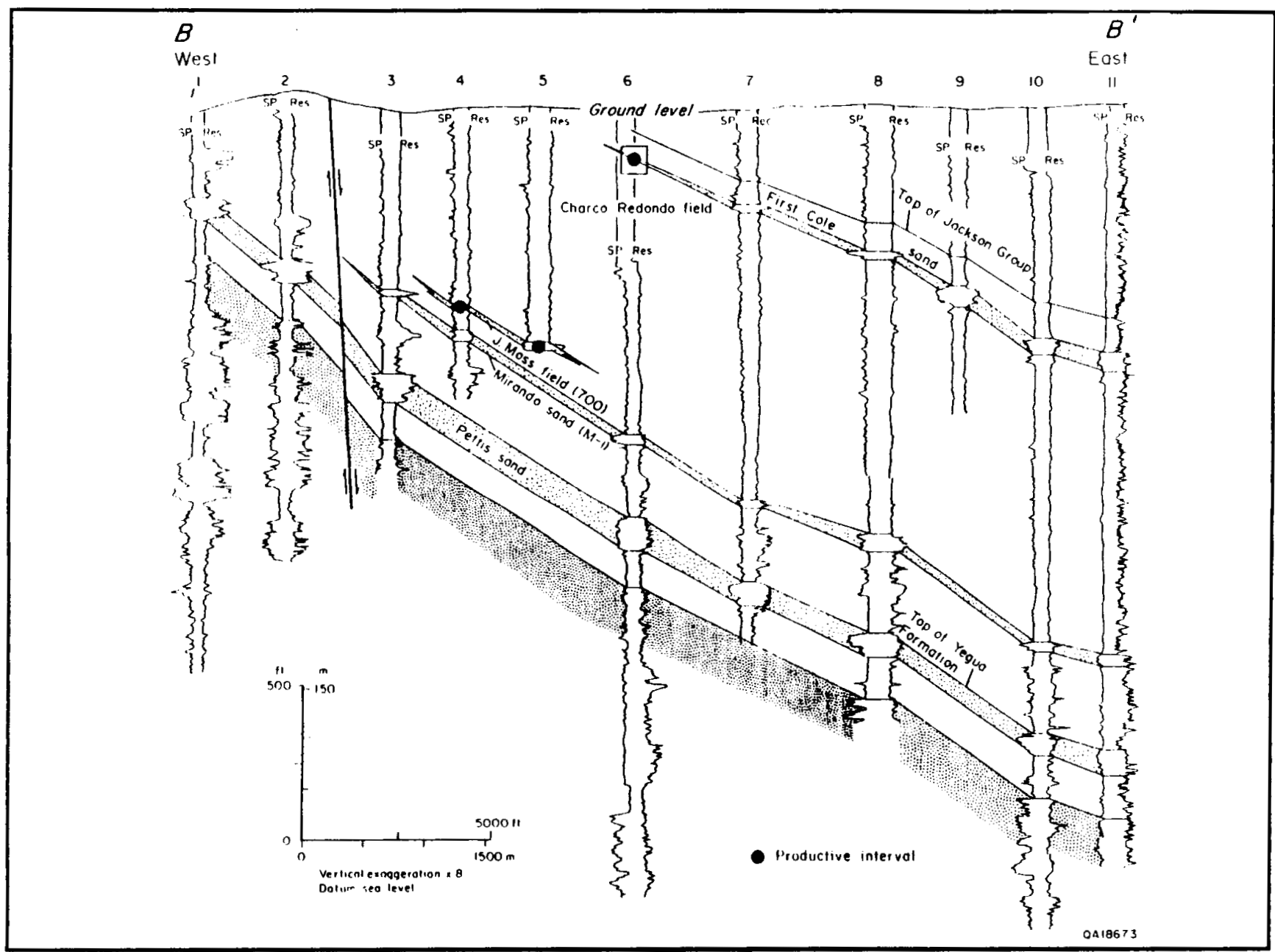

Figure 23. Dip-oriented, structural cross section B-B' illustrating structure of lackson Group and updip pinch-out of upper Jackson Group sand bodies. The cross section is labeled as local structure section in figure 19. Well names are listed in appendix 2. 


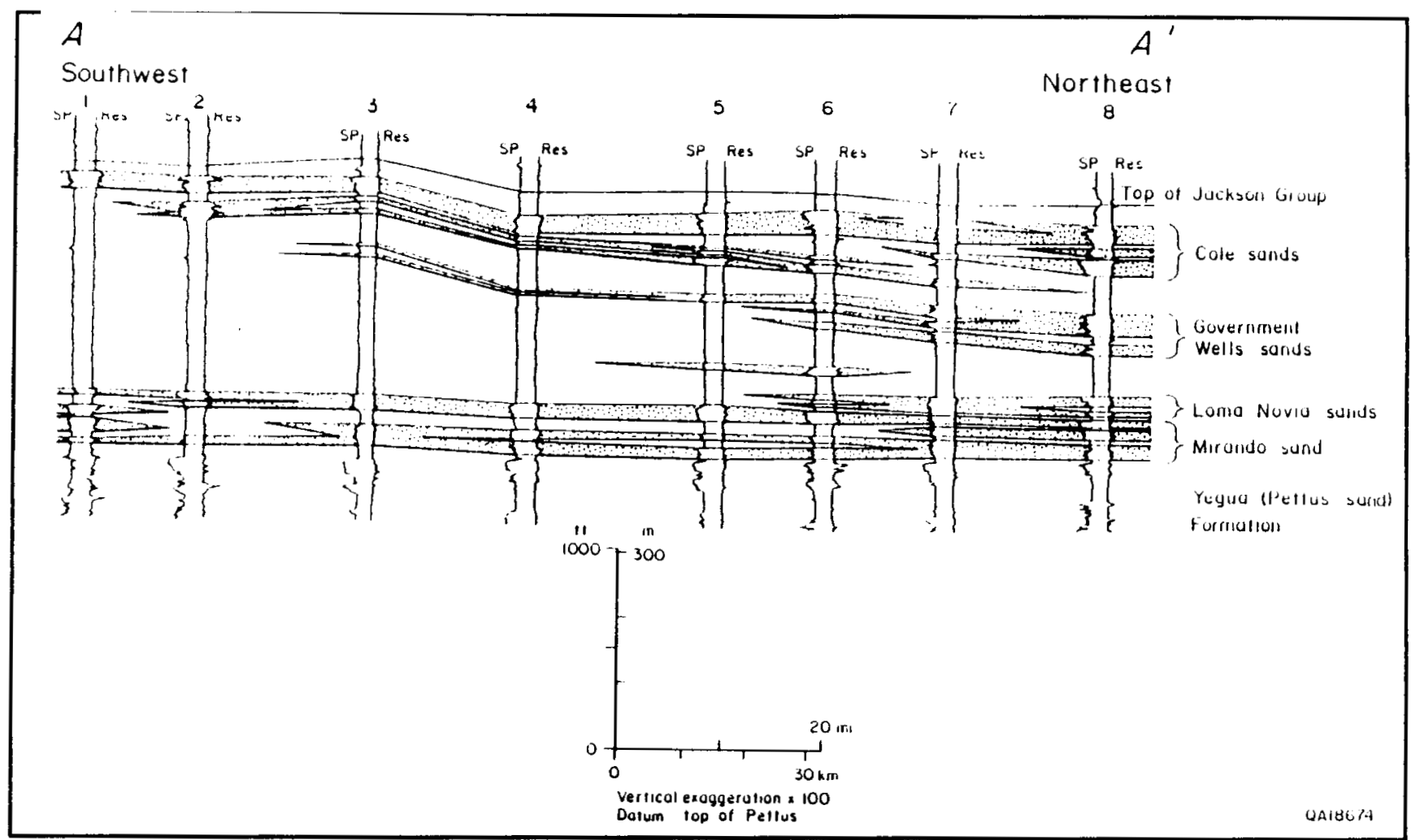

Figure 24. Strike-oriented cross section A- $\hat{A}^{\prime}$ illustrating lateral continunity of Jackson Group sand bodies. The cross section is labeled as regional strike section in figare 19. The section demonstrates the decrease in sandstone from northeast to southwest. Datum is top of Yegua (Pettus sand) formation. Well names are listed in appendix 2.

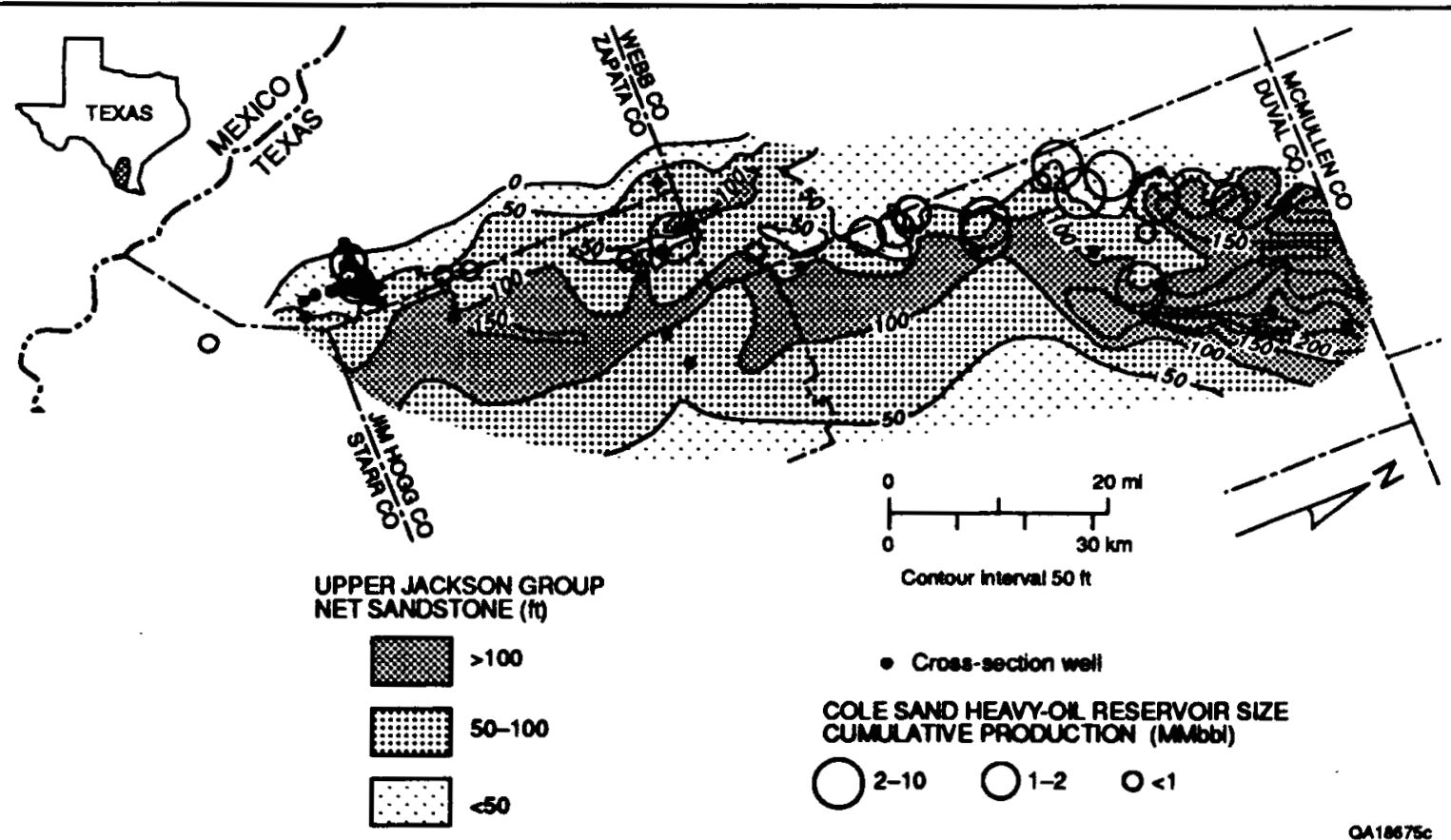

Figure 25. Map of net sandstone thicknese of upper lackoon Group including the Cole and Government Wells sands. Net sandstone is thickest in northem Duval County. The strike-parallel orientation of the axis of thick net sandstone supports the interpretation that upper lackson Group sandatones accumulated principally in barrier/strandplain depositional environments similar to environments of deposition of sandstones of the lower Jackson Group. Heavy-oil reservoirs are preferentially located along updip pinch-out of sandstones. 


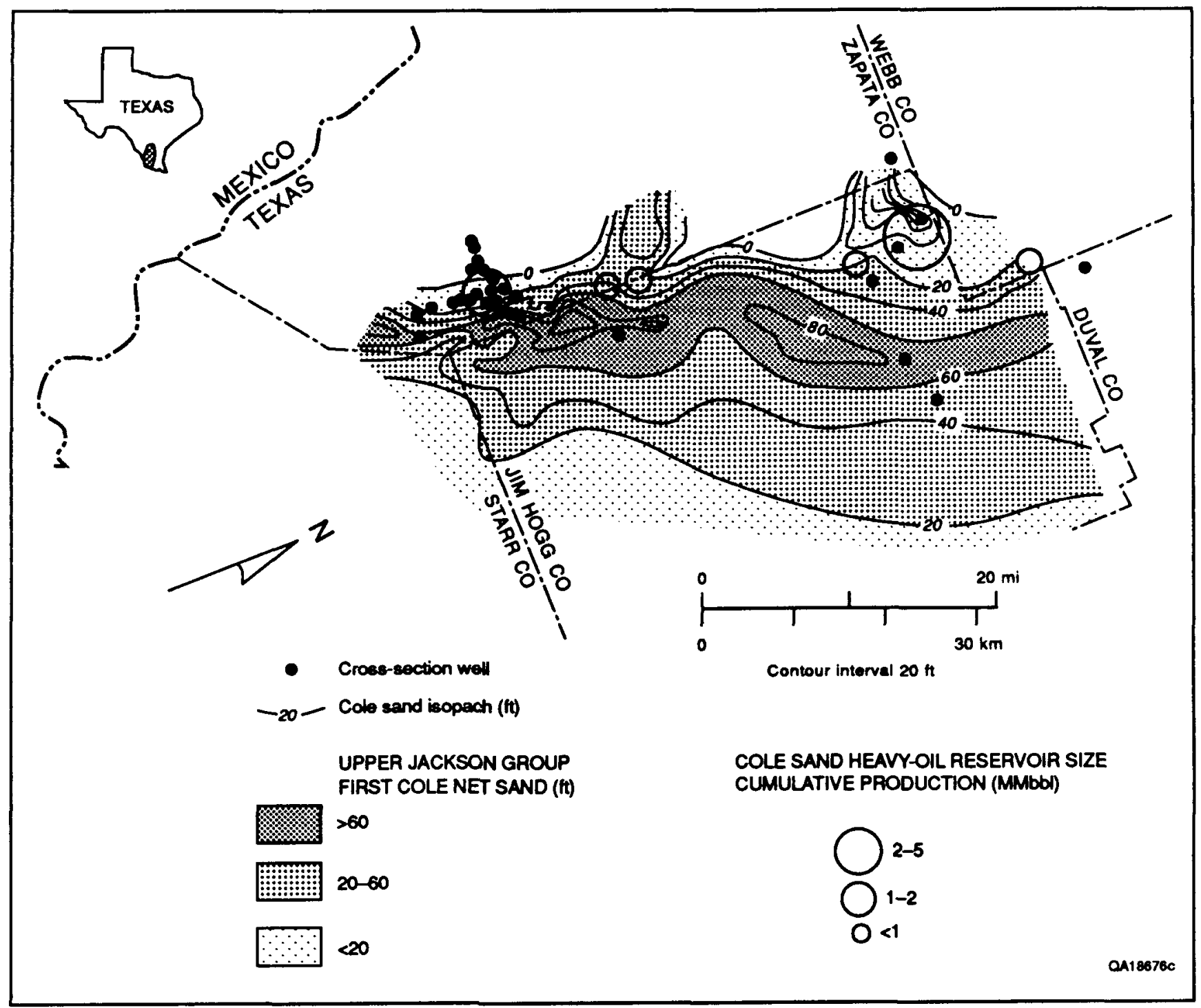

Figure 26. Map of net sandstone thicleness of first Cole sand in lim Hog; and Zapata Counties. Heavy-oil reservoirs are preferentially located along updip pinch-out where sandotone thicloness is les than $20 \mathrm{ft}$.

net sandstone in the upper Jackson has prograded basinward $15 \mathrm{mi}(24 \mathrm{~km})$ in the northern part of the study area from the location of the axis for the lower Jackson. However, little seaward progradation of the axis of thick net sandstone occurred in the southem part of the study area, where the Jackson Group is thicker.

A sand-percent map of the lower part of the Jackson Group illustrates the linear strike orientation of the sandstone belt (fig. 22) (Kaiser and others, 1980). A net-sandstone map of the upper Jackson (fig. 25) (including the Cole and Covernment Wells sandstones) shows a similar strike orientation of sandstone thickness. Sand-body orientation and net sandstone thickness exert a strong control on the location of heavy-oil reservoirs (fig. 25).
Heavy-oil reservoirs at Charco Redondo, Ed Lasater, Alworth, Bruja Vieja, Las Animas-Lefevre, and Bruni South fields are located along the updip pinch-out where net sandstone thickness is less than $100 \mathrm{ft}(<30 \mathrm{~m})$. At Charco Redondo field the upper Cole sand is 10 to $20 \mathrm{ft}$ $(3$ to $6 \mathrm{~m})$ thick. Reservoir traps form in updip facies by losing porosity through (1) sand-body pinch-out and (2) increasing percentage of clay in the sand body.

The updip and downdip pinch-out of a single Cole sand body in lim Hogg and Zapata Counties can also be demonstrated within a vertically restricted stratigraphic section. The thickness of the first Cole sandstone is as much as $100 \mathrm{ft}(\leq 30 \mathrm{~m})$ and its width is approximately 8 to $10 \mathrm{mi}$ (13 to $16 \mathrm{~km}$ ) (fig. 26). 


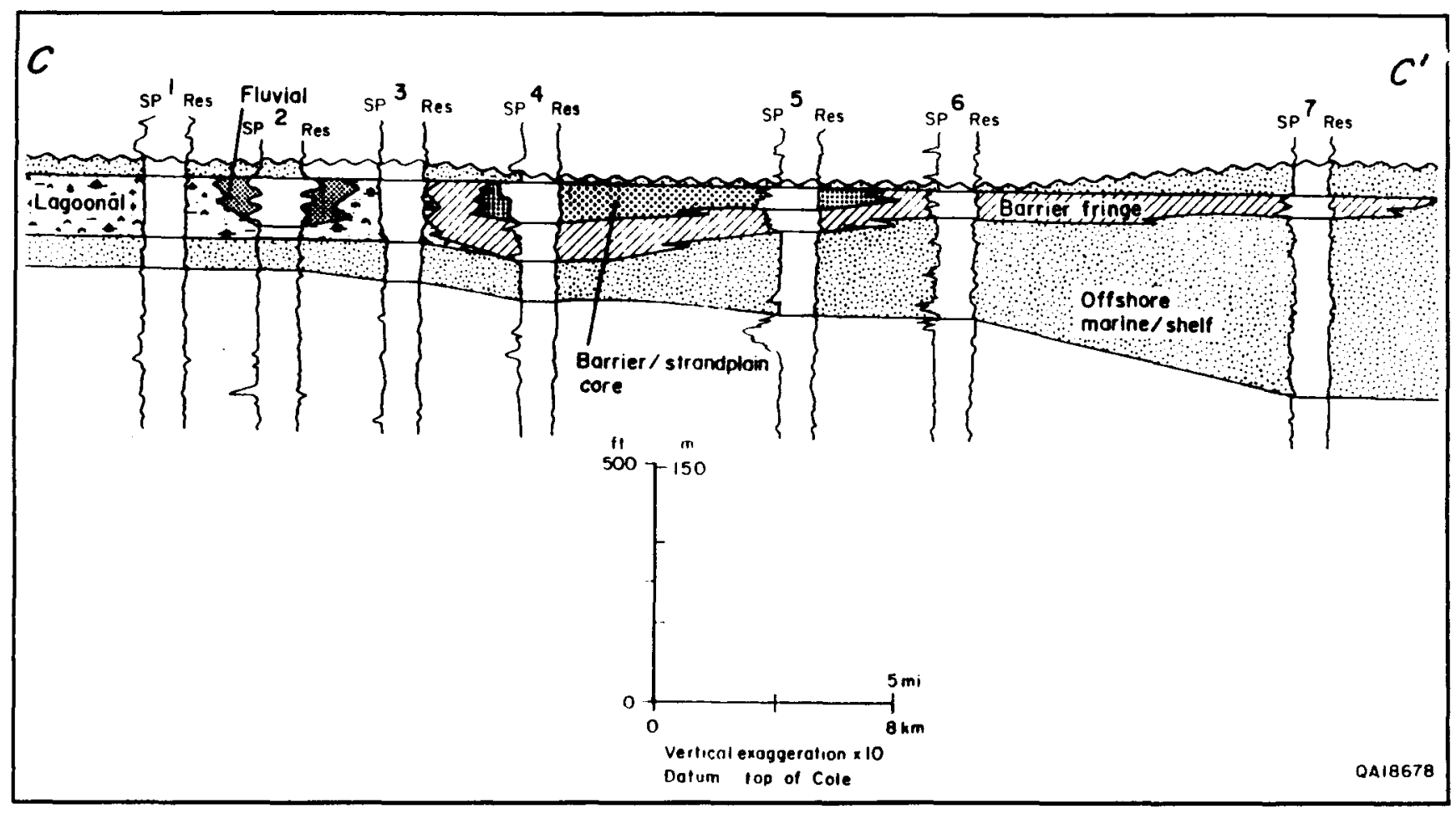

Figure 27. Cross section illustrating $C-C^{\prime}$ facies relationships in first Cole sand. Cross section is labeled as facies dip cross section in figure 19. Datum is top of first Cole sand. Well names are listed in appendix 2.

\section{Depositional Facies}

Reservoir sandstones in the Mirando Trend (and Jackson-Yegua Barrier/Strandplain Sandstone play) are in the barrier bar/strandplain system of the Jackson Group and Yegua Formation. This study focused on the Jackson Group, which contains the most reservoirs. Sand-rich barrier bar/strandplain facies are surrounded by mudstones. Updip to the west, mudstones generally were deposited in lagoonal environments with secondary floodplain environments; downdip to the east, mudstones were dominantly deposited in shelf environments. A diporiented facies cross section illustrates lateral relationships between depositional facies and indicates that the sandstones were deposited in a variety of sand-rich depositional environments (fig. 27).

Thickness relationships and log character were used to identify depositional facies (figs. 27 and 28). A depositional facies map (fig. 28) of the first Cole sandstone indicates that heavy-oil reservoirs are located along the updip pinch-out of barrier-fringe facies against lagoonal mudstones. Sand-body thickness is greatest in the barriercore and strandplain sandstones that are characterized by progradational base and blocky tops. Lagoonal mudstones are present updip of barrier bar/strandplain sandstones. Barrier-core and back-barrier sandy facies rapidly grade updip into sand-poor lagoonal facies. Fluvial facies are isolated within muddy lagoonal facies on the landward updip margin of the sand-rich belt. Within the lagoonal mudstones are isolated, dip-oriented fluvialdeltaic sandstones consisting of thin upward-coarsening packages at the base and multiple upward-fining packages at the top. Fluvial-deltaic sandstones apparently did not prograde across the extensive lagoonal mudstones and breach or feed the barrier bar/strandplain in the study area. Southward thinning of net sandstone and strike-oriented sandstone trends indicate that longshore drift probably supplied sand from the north, where progradation of the shoreline was the most extensive. In a basinward direction, barrier-fringe sandstones thin gradually and are replaced by offshore mudstones and siltstones. 


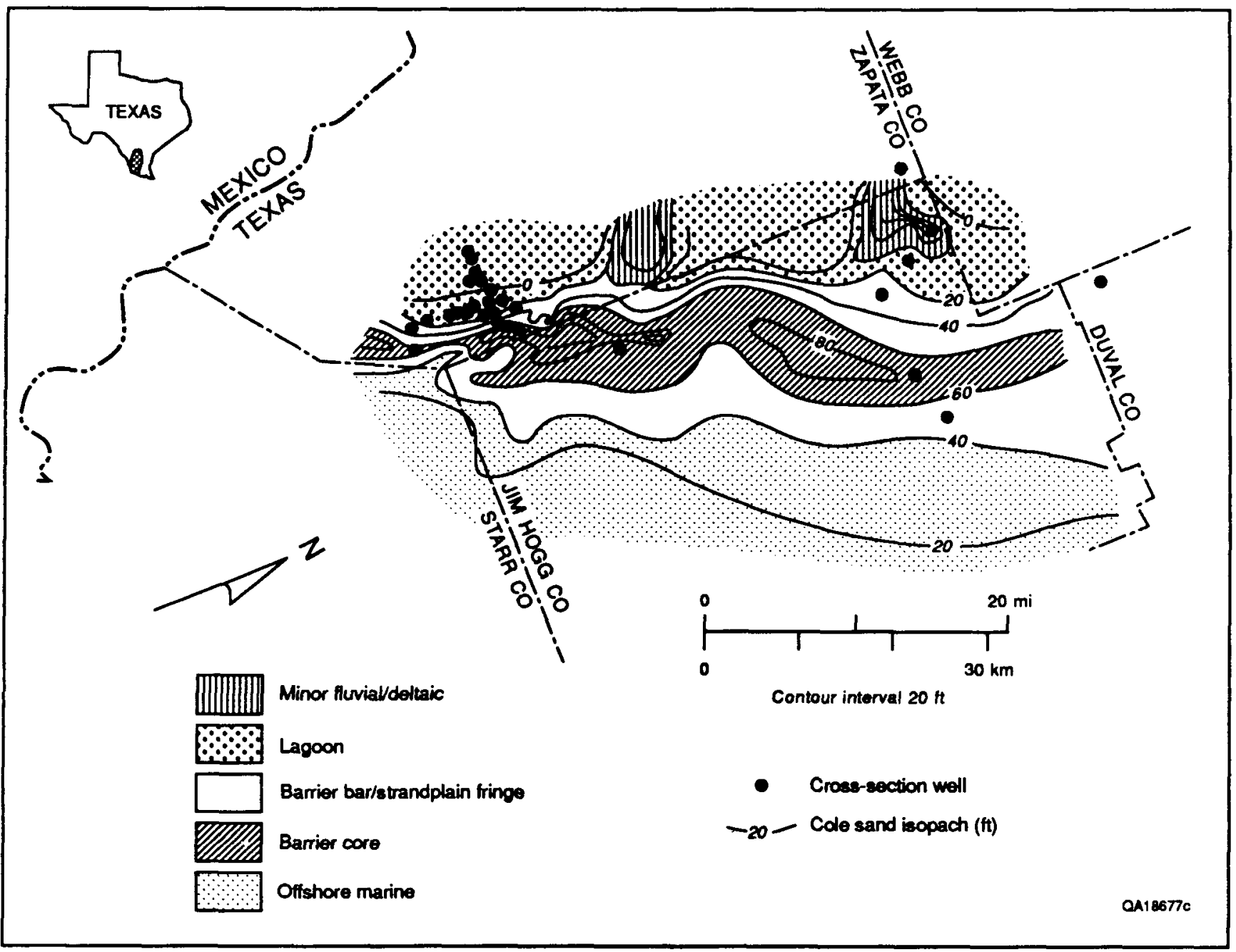

Figure 28. Map of depositional facies of first Cole sand.

\section{Reservoir Texture and Diagenesis}

The abundant core allowed sandstone texture and mineralogy to be characterized at Charco Redondo field, which is associated with the updip pinch-out of the first Cole sand (figs. 23 and 29). The oil reservoir at Charco Redondo field is typically a friable, uncemented, clean fine sandstone that coarsens upward as the percentage of fine silt and clay declines (figs. 29 and 30). Fabric has been destroyed by drilling or burrowing organisms. Textural analysis indicates that the reservoir sandstones are poorly to well sorted, strongly fine skewed, and medium to fine grained, and they contain 75 to 95 percent sand and 1 to 7 percent day. Burrowed, oysterbearing, fine sandy mudstones overlie and underlie the reservoir. The surrounding mudstones are very poorly sorted and fine skewed, a subequal mixture of fine sand and silt with 15 to 22 percent clay. Thin calcite-cemented zones within the reservoir are tight and apparently affect the distribution of the oil (figs. 29 and 30).

Swelling smectite clays are present in mudstones that encase the reservoir. $X$-ray diffraction analysis was done to identify clay mineralogy (fig. 31), and reservoir sandstones at Charco Redondo field were found to contain a relatively low percentage (1 to 7 percent) of smectite clays. The presence of smectite clays in other heavy- and medium-oil reservoirs in the Jackson Group is likely to be common owing to the similar depositional and diagenetic history. The percentage of clay minerals in a given reservoir is expected to depend on the location of the reservoir with respect to sand-body pinch-out and to depositional facies.

A detailed cross section based on closely spaced cores $(50 \mathrm{ft}[15 \mathrm{~m}]$ ) reveals diagenetic heterogeneities related to the presence of low-permeability zones of calcite- 


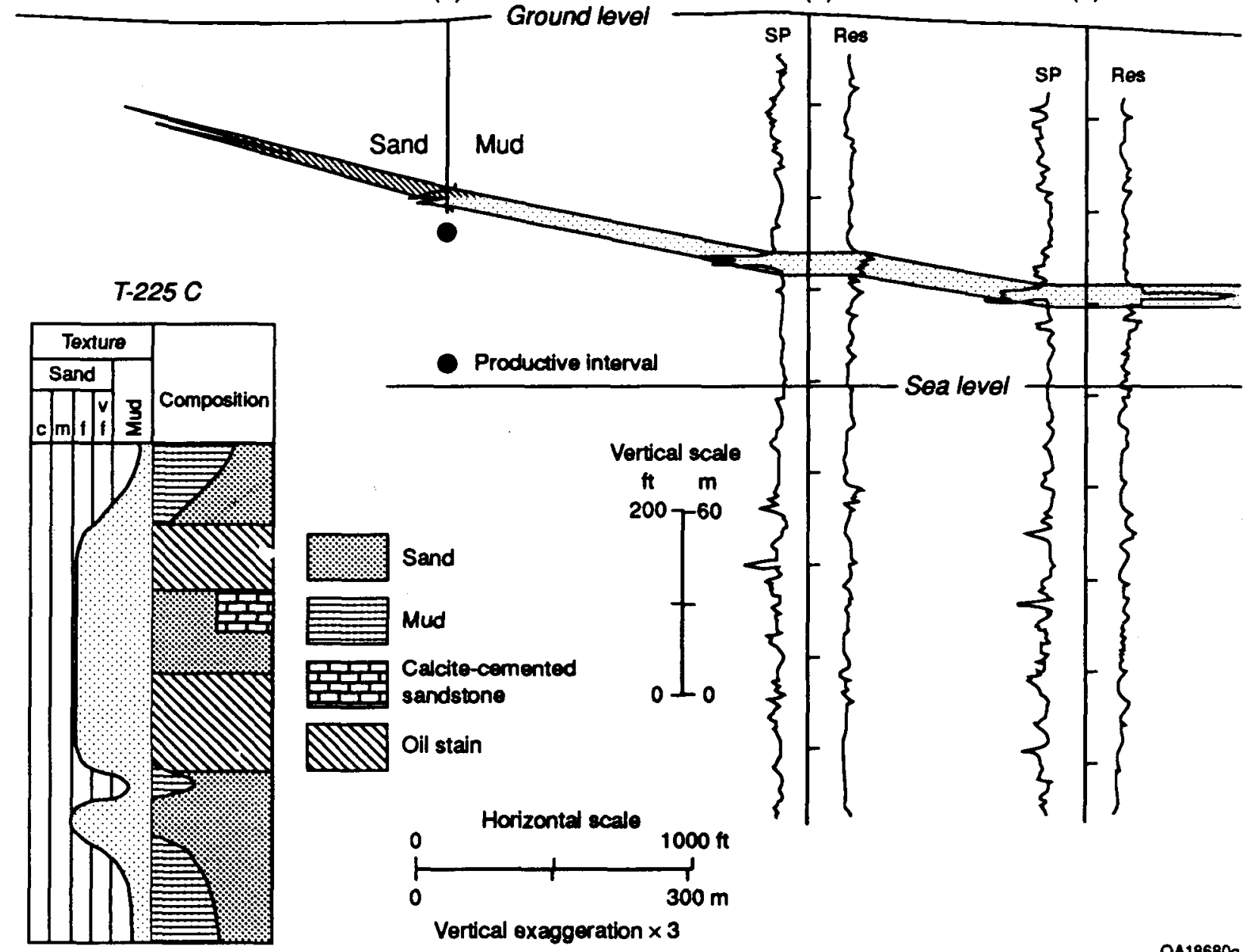

OA18680c

Figure 29. Cross section showing updip pinch-out of first Cole sand at Charco Redondo field. Textural and compositional variations based on description and analysis of core from Charco Redondo field. Well names are listed in appendix 2.

cemented sandstone that apparently segment heavy-oil reservoirs at Charco Redondo field (fig. 32). In an updip position, offlapping calcite-cemented zones occur in the upper part of the sandstone body, dip basinward, and extend to the lower parts of the sandstone body in a downdip position. These zones apparently formed along accretionary-grain surfaces that cross the sand body.

Porosity/permeability plots of reservoirs in the upper Cole sand at Charco Redondo and Seventy-Six West fields reveal a large population characterized by high porosity and permeability and a smaller group characterized by low porosity and permeability (fig. 33). Core analyses indicate zones with high porosity ( 25 to 35 percent) and permeability (100 to $3,000 \mathrm{md}$ [1.0 $\times 10^{-1}$ to $2.96{\mu \mathrm{m}^{2}}^{2}]$ ) are separated by calcitecemented zones with low porosity (5 to 15 percent) and permeability $\left(0.001\right.$ to $10 \mathrm{md}\left[1.0 \times 10^{-6}\right.$ to $1.0 \times 10^{-2} \mu^{2}$ ]) (fig. 32). The low-permeability, calcitecemented zones apparently segment the reservoirs into compartments, interupting resenoir-drainage and potentially affecting pattways of injected geathermal fluids. 


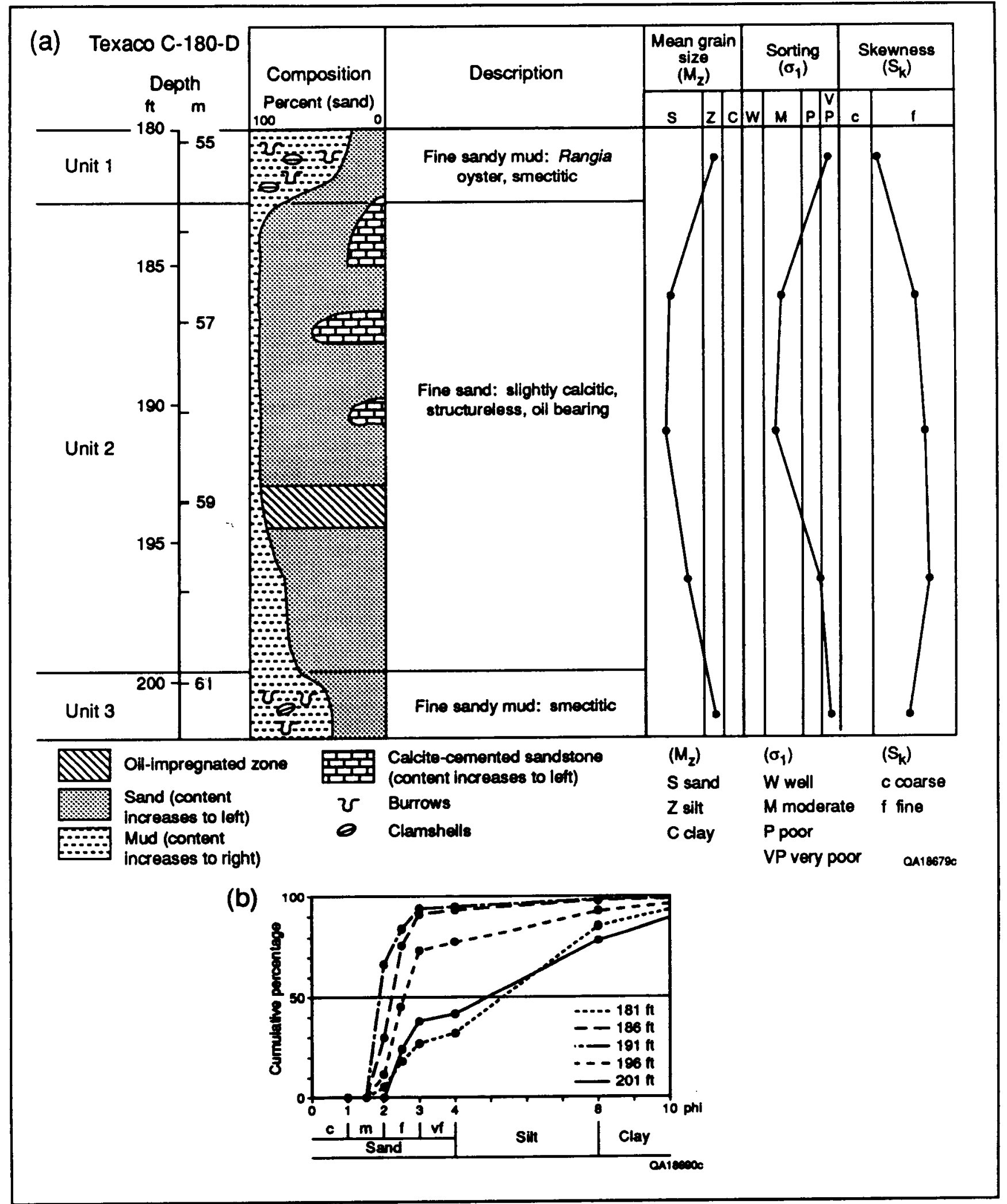

Figure 30. (a) Description of core from upper lackoon Group first Cole sand at Charco Redondo field, Zapata County. (b) Textural data based on wet sieve analysis. Compositional variations result langely from variations in the percentage of matrix clay and silt that is admixed with the abundant fine to medium sand. 


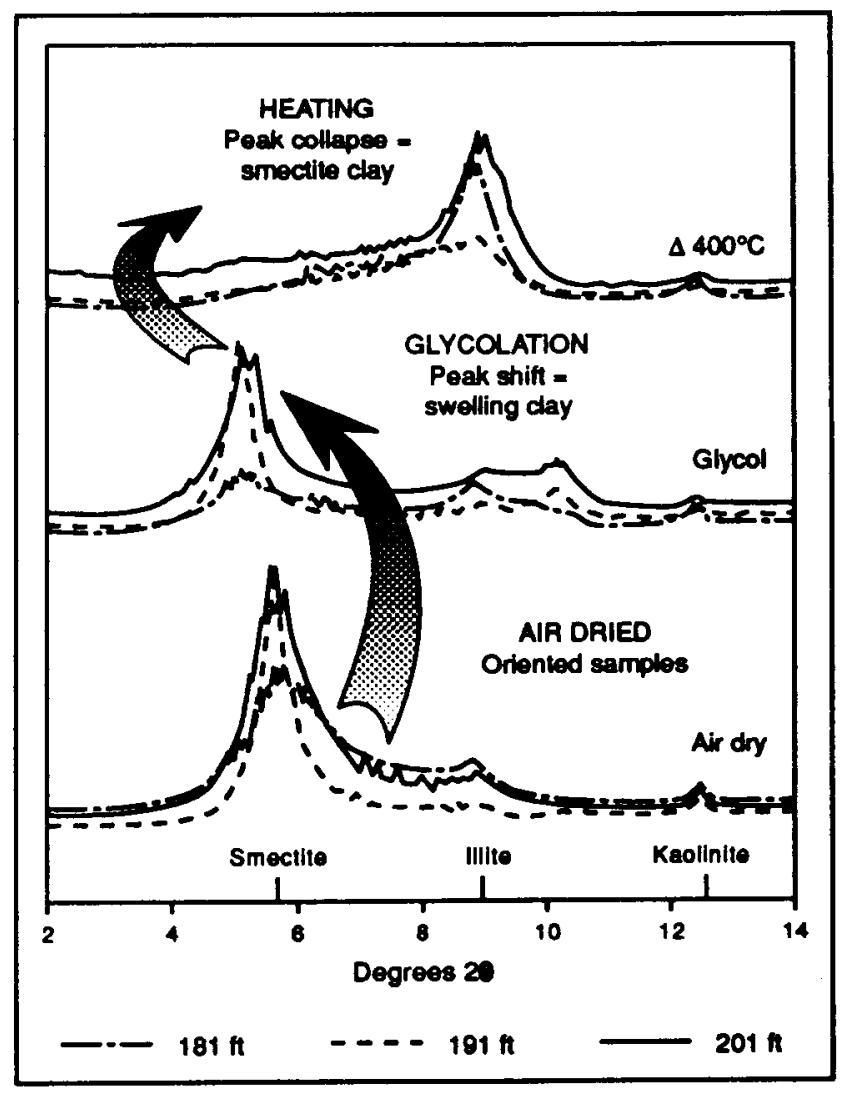

Figure 31. Clay mineral analysis determined by $X$-ray diffraction of finer than 2 um separates from first Cole sand from Charco Redondo field, Zapata County. Smectite is the dominant clay mineral in all three samples, illite is present in samples 181 and 201, and kaolinite is present in trace amounts in all three samples. The shift of the smectite peak during glycolation and heating and collapse during heating indicates the presence of swelling clays.

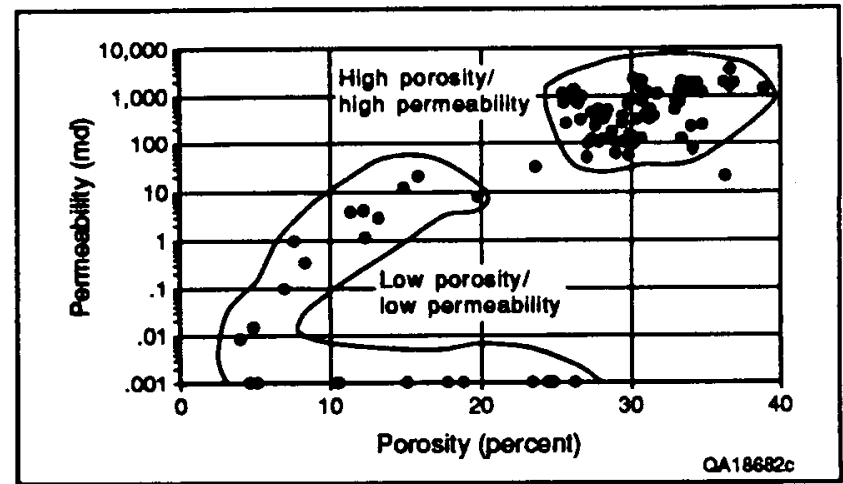

Figure 33. Plot of porosity and permeability from Charco Redondo and Seventy-Six West fields. Most samples are in one of two classes: high porosity $(>25 \%)$, high permeability ( $>100$ md); and low porosity $(<25 \%)$, low permeability (<10 md). Samples with low permeability and low porosity are thin calcite-cemented sandstones.

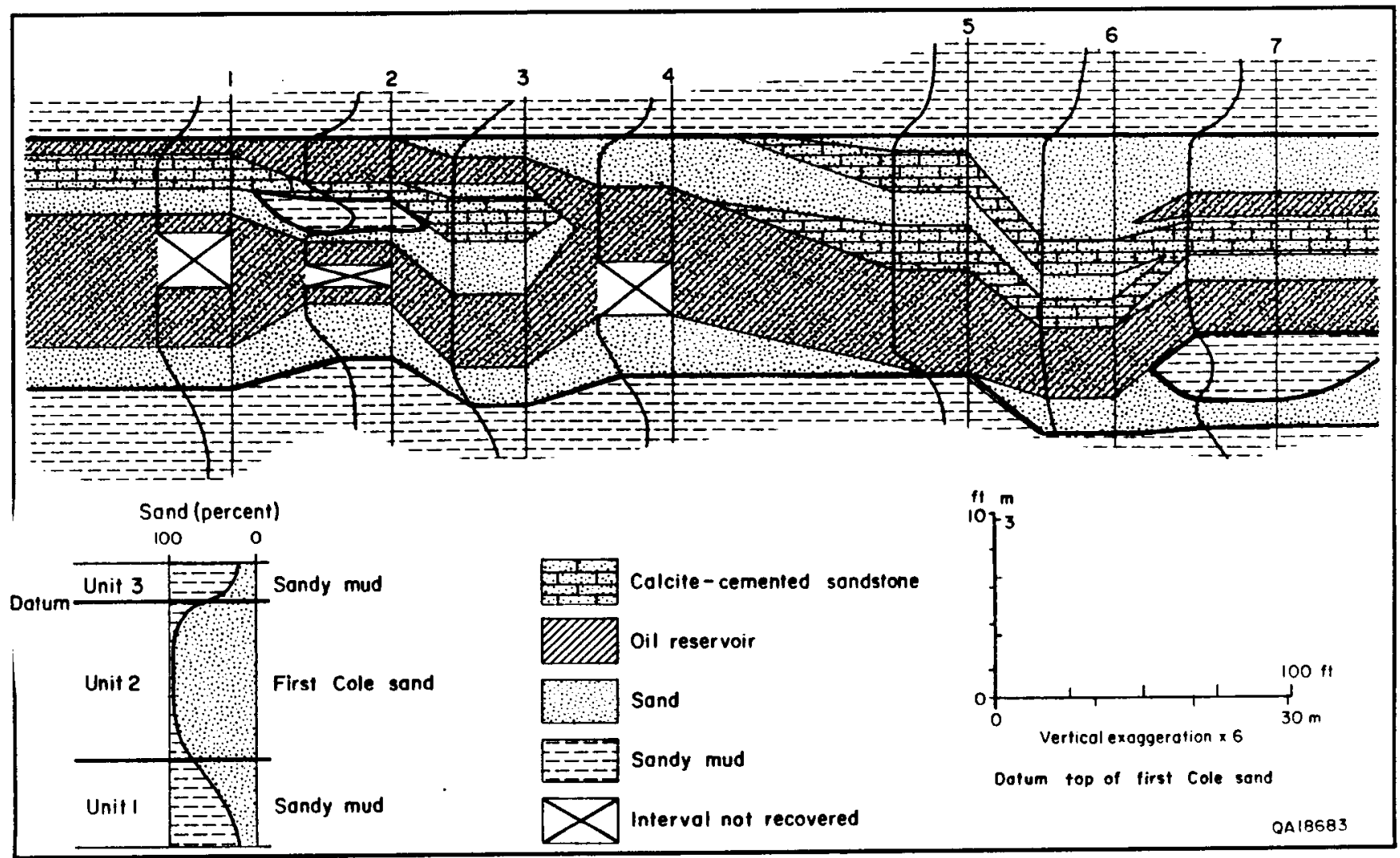

Figure 32. Cross section of Charco Redondo field utilizing core descriptions. Core consisted predominantly of disaggregated sand as a result of shallow depth of burial $(180$ to $200 \mathrm{ft}$ [55 to $60 \mathrm{~m}])$. Thin calcite-cemented sandstones and muddy intervals appear to be flow barriers that segment the reservoir into compartments. Well names are listed in appendix 2. 


\section{Suitability of South Texas Heavy-Oil Reservoirs for Thermally Enhanced Oil Recovery}

The proximity of heavy-oil reservoirs to geothermal corridors is necessary for geothermal fluids to be used in a geothermally enhanced oil recovery process. However, proximity alone does not automatically ensure the commercial or technical feasibility of the process. Characteristics of the potential target oil and geothermal reservoirs must be carefully considered. Conditions significant for a possible geothermally enhanced oil recovery process in the South Texas area include the (1) size of heavy-oil reservoirs, (2) relatively shallow, thin heavy-oil reservoirs with thin oil columns, (3) generally excellent porosity and a permeability complicated by low-pern eability barriers, (4) swelling clays in oil reservoirs, and (5) low permeability in the geothermal reservoir.

Small reservoir size is a major impediment to thermal recovery techniques because the added expense per barrel $\left(\mathrm{m}^{3}\right)$ of thermally recovered oil would be high. Heavy-oil reservoirs in the Mirando Trend tend to be small. The $\mathbf{2 6}$ heavy-oil reservoirs that overlie the South Texas Wilcox geothermal fairway have a total cumulative production of only $32.9 \mathrm{MMbbl}\left(5.2 \times 10^{6} \mathrm{~m}^{3}\right)$, or an average of $1.3 \mathrm{MMbbl}\left(2.1 \times 10^{5} \mathrm{~m}^{3}\right)$ per reservoir. Of the large reservoirs in Texas, excluding the supergiant Hawkins Woodbine reservoir, the heavy-oil fields have the smallest average size of $28 \mathrm{MMbbl}\left(4.4 \times 10^{6} \mathrm{~m}^{3}\right)$, and medium reservoirs have an average size of $60 \mathrm{MMbbl}$ $\left(9.5 \times 10^{6} \mathrm{~m}^{3}\right)$.

The shallow depths of heavy-oil reservoirs (mean depth of $1,512 \mathrm{ft}$ [ $461 \mathrm{m]}$ ) constrain the upper limit of injection pressures to prevent fracture of the reservoir. However, even at these relatively shallow depths, injected geothermal fluids at $350^{\circ} \mathrm{F}\left(177^{\circ} \mathrm{C}\right)$ will still be hot water and not steam. Although hot water is a less efficient mobilizing agent than steam, such inefficiency would be mitigated if an abundant supply of low-cost geothermal water were available.

A thin, blanket-type oil column in a thin reservoir that pinches out updip is an ideal geometry for favorable sweep efficiencies of conventional (nonthermal) water floods. However, the thinness of the reservoir is unfavorable for hot fluids because heat loss to the surrounding country rock will be high (Martin and others, 1972). Although the lateral continuity of heavyoil reservoirs is generally favorable for minimizing reservoir compartmentalization, diagenetic calcitecemented zones have compartmentalized the oil reservoir at Charco Redondo field. Complex lateral facies variations are also likely to segment the oil reservoir. Such zones are thought to be common in other heavy-oil reservoirs of the Mirando Trend. A complete characterization of calcite-cemented zones and facies distribution would help to predict how reservoir performance is affected by flow barriers.

Injection of foreign fluids into an oil reservoir is of concern because of possible reactions that could adversely affect oil production. A common undesirable reaction encountered during injection of fresh water or steam into a reservoir is plugging of pore throats as a result of swelling of smectite clays. Such plugging reduces porosity and permeability. Smectite clays are susceptible to swelling when fresh water becomes bound into the clay structure. High-salinity fluids do not cause smectite clays to swell. Although smectite is present in Mirando Trend reservoirs, the percentage of clay in a given Mirando Trend reservoir is going to be variable and controlled primarily by depositional facies distribution and the relation of oil reservoir to its updip pinch-out.

Inability to predict salinity distribution in the deep upper Wilcox makes the potential problem of swelling clays difficult to assess. The salinity of formation waters is controlled by a complex and poorly understood interaction between local and regional geology, faults, compaction, bulk mineralogy, clay diagenesis, temperature, fluid migration and composition, and salt tectonics (Gregory and others, 1980). Geothermal resenoirs along the Texas Gulf Coast display wide variations in salinity within generalized trends. Salinity typically increases with depth to the geopressured zone. In the geopressured zone salinity decreases. In the deepest zone, salinity trends become unpredictable. Generally, in the South Texas area, the salinity is lower (in the range of $<10,000 \mathrm{ppm}$ to $>\mathbf{8 0 , 0 0 0} \mathrm{ppm}$ ) than it is at comparable depth along the upper Texas coast, reflecting 
the general paucity of halite deposits and salt domes (Gregory and others, 1980; Hamlin and others, 1989).

Geothermal fairways in Tertiary strata in the South Texas area, including the Frio, Vicksburg, and upper Wilcox reservoirs, were originally not considered favorable for high-volume production $(20,000 \mathrm{bbl} / \mathrm{d}$ [0.037 $\mathrm{m}^{3} \mathrm{5}^{-1}$ ]) of geothermal fluids owing to generally poor resenoir quality (low permeability) compared with that of other geothermal fairways (Bebout and others, 1978; Loucks, 1979; Bebout and others, 1982). However, production rates from South Texas geothermal reservoirs are likely to be as much as $2,000 \mathrm{bbl} / \mathrm{d}$ $\left(\leqslant 0.004 \mathrm{~m}^{3} \mathrm{~s}^{-1}\right)$, which may be adequate for geothermally enhanced oil recovery.

\section{Favorable Colocation Characteristics}

A computerized data fite at the Railroad Commission of Texas (RRC) was accessed to determine the status of existing wells drilled after 1970 in South Texas that might serve as suitable geothermal wells at a fraction of the cost of drilling a geothermal design well. The wells examined are from the inventory of well logs on file at the Bureau of Economic Ceology (BEG). The South Texas well log data base at the BEG exceeds 700 wells, including shallow Jackson logs (100 to $3,000 \mathrm{ft}$ [30 to $914 \mathrm{ml})$ and deeper Wilcox logs (>8,000 ft $(>2,438 \mathrm{ml})$. BEG has acquired logs from more than 90 percent of the wells in the South Texas area that penetrate through the upper Wilcox. The status of post-1970 wells in the BEG file (266 wells) is as follows: 44 percent (118) are current producers, 23 percent (60) are abandoned producers, 21 percent (55) are plugged and abandoned, 12 percent (33) were not inventoried by the RRC, and pre-1970 wells with logs in the Wilcox interval (294 wells from the BEG well file) have an average depth of 7,238 $\mathrm{ft}(2,206 \mathrm{~m})$, whereas post-1970 wells have an average depth of $12,836 \mathrm{ft}(3,912 \mathrm{~m})$. Of the groups of well types examined, abandoned gas wells were considered most favorable because they are likely to be deep, to have intact casing, and to have an existing infrastructure of pipelines and other production facilities. Abandoned gas-producing wells have the deepest average depth of $14,765 \mathrm{ft}(4,500 \mathrm{~m})$. Appendix 4 lists abandoned gas wells in the South Texas five-county area that have a drilled depth below $8,000 \mathrm{ft}(2,438 \mathrm{~m})$ and are in the inventory of well logs on file at the BEG.

A $2.5-\mathrm{mi}(4-\mathrm{km})$ radius was plotted around abandoned gas-producing wells in the South Texas colocation area to determine the extent of colocation of the wells and potential heavy- and medium-oil reservoirs (fig. 34). The boundaries of 38 heavy-and medium-oil fields in the Jackson Group contact or lie within a $2.5-\mathrm{mi}(4-\mathrm{km})$ radius around abandoned gas wells in the upper Wilcox in the South Texas colocation area. Approximately 35 abandoned gas wells exist within a $2.5-\mathrm{mi}(4-\mathrm{km})$ radius of a heavy-oil or large reservoir field. Fifty-two percent of the heavy-oil fields in the South Texas area are within $2.5 \mathrm{mi}(4 \mathrm{~km})$ of an abandoned well in the deep upper Wilcox, whereas 65 percent of the large $(>10 \mathrm{MMbbl}$ (>1.6 $\left.\times 10^{6} \mathrm{~m}^{3}\right]$ ) reservoirs in the Jackson Group (Galloway and others, 1983) are within the same radius. On the basis of surface distance alone, many deep abandoned gas wells are favorably located with respect to heavy- and medium-oil reservoirs.

The productivity of abandoned gas wells (water temperature and water production rates) is not addressed in this report. However, temperatures at a given depth can be estimated in South Texas Wilcox wells on the basis of corrected bottom-hole temperature versus depth (fig. 6) from all wells in the South Texas BEG log file that penetrate the Wilcox. At the average depth of $14,765 \mathrm{ft}$ $(4,500 \mathrm{~m})$ for abandoned gas-producing wells in South Texas, the average temperature would be $377^{\circ} \mathrm{F}\left(192^{\circ} \mathrm{C}\right)$.

The comentional production casing size of $51 / 2$ inches for the deep upper Wilcox gas wells allows a tubing size of $31 / 2$ inches $(8.9 \mathrm{~cm})$ or $23 / 8$ inches $(6.0 \mathrm{~cm})$ to fit inside. With conventional casing and tubing, production rates for geothermal fluids typically are limited to less than 20,000 bbl/d $\left(<0.037 \mathrm{~m}^{3} \mathrm{~s}^{-1}\right)$. However, wellproductivity limits imposed by standard casing and tubing diameters should not be a significant constraint when the geothermal fluids are to be used for hot-water flooding. During conventional waterflooding in Jackson Group oil resenoirs in South Texas, injection rates are 400 to $600 \mathrm{bbl} / \mathrm{d}\left(7.4 \times 10^{-4} \mathrm{~m}^{3} \mathrm{~s}^{-1}\right.$ to $\left.1.1 \times 10^{-3} \mathrm{~m}^{3} \mathrm{~s}^{-1}\right)$ for injection wells (RRC hearings files for Seventy-Six West field). $A$ line of five injection wells with an injection rate of $500 \mathrm{bbl} / \mathrm{d}\left(9.0 \times 10^{-4} \mathrm{~m}^{3} \mathrm{~s}^{-1}\right)$ would require a single geothermal well producing $2,500 \mathrm{bbl} / \mathrm{d}$ $\left(4.6 \times 10^{-3} \mathrm{~m}^{3} \mathrm{~s}^{-1}\right)$. Abandoned gas wells could form a costeffective conduit for accessing geothermal reservoirs because as a group they are relatively deep and can contain relatively hot water. 


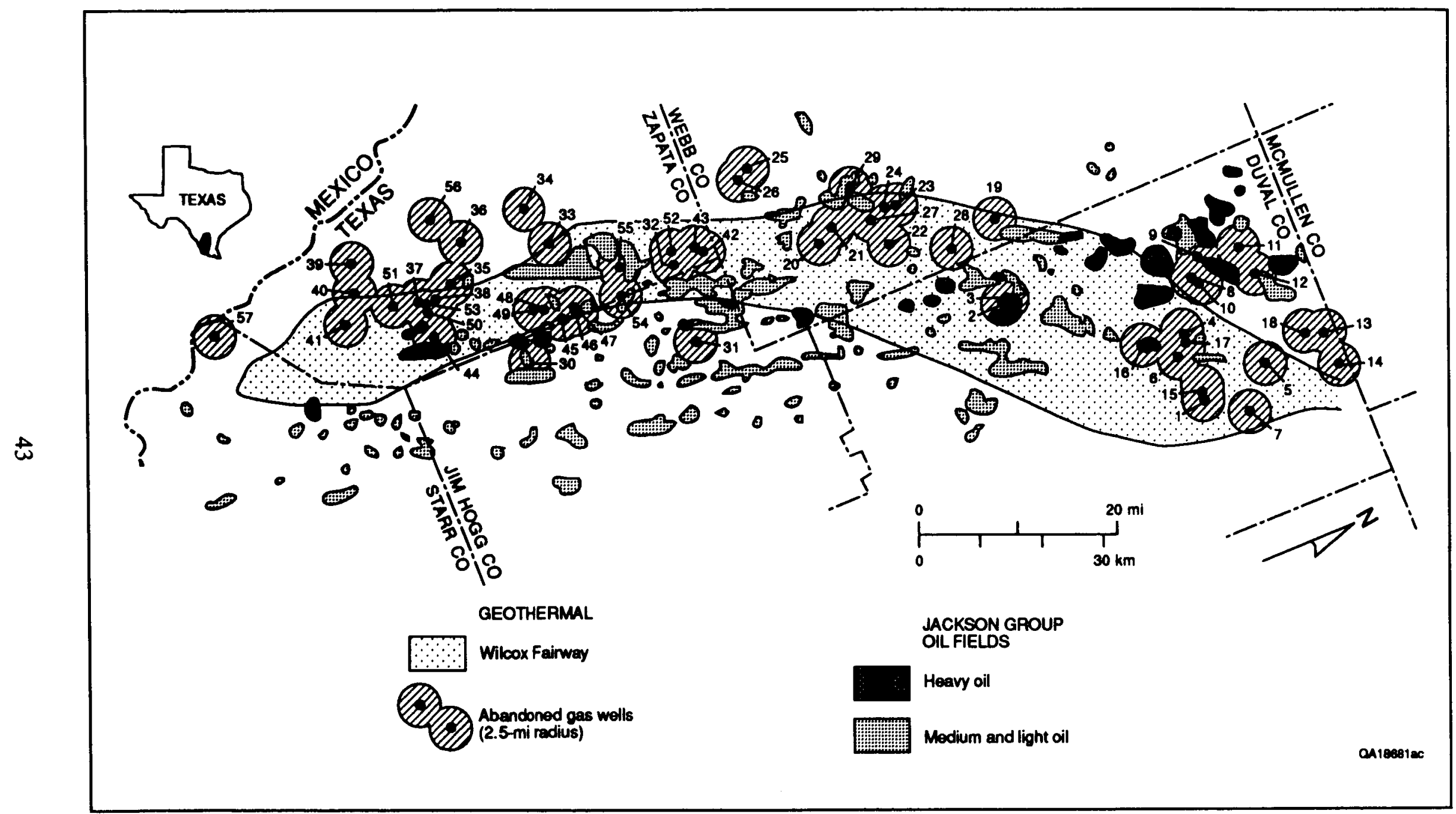

Figure 34. Map showing location of deep abandoned gas wells, oil fields in the upper fackeon, and the South Texas geothermal corridor. A 2.5-mi (4.0-km) radius around the abandoned gas wells intercepts more than half of all heavy-oil reservoirs in the geothermal corridor. Appendix 3 lists the following data for mumbered abandoned gas wells: unique BEG identification number, operator/well name, field, and reservoir. 


\section{Conclusions}

1. The best region in Texas to test the viability of using geopressured-geothermal fluids to improve oil recovery is South Texas, where abundant heavyoil reservoirs of the Jackson Group immediately overlie geothermal fairways in the upper Wilcox Group. Mirando Trend medium- and heavy-oil reservoirs are well suited for testing TEOR techniques because they have generally excellent porosity and permeability but low recovery efficiency as a result of high oil viscosity. The relatively small size of the heavy-oil reservoirs is a disadvantage.

2. Approximately 35 abandoned gas wells that penetrate the deep, upper Wilcox in the South Texas colocation area are within $2.5 \mathrm{mi}(4 \mathrm{~km})$ of reservoirs containing heavy and medium oil in the overlying Jacksin Group. With appropriate workover, abandoned gas wells may serve as costeffective geothermal wells.

3. In the South Texas colocation area, heavy-oil reservoirs are concentrated in the Jackson Group Cole sandstone, whereas medium-oil reservoirs are concentrated in the Government Wells, Loma Novia, and Mirando sandstones. The medium-oil resource is larger than the heavy-oil resource. Microbial degradation and fresh-water washing of light oil are inferred to have concentrated the heavy oil in the shallower Cole sandstone reservoirs.

4. Jackson Group sandstones in South Texas are characterized by a sheetlike geometry as a consequence of deposition in barrier bar/strandplain environments and are surrounded by lagoonal and shelf muds. Heavy- and medium-oil reservoirs in
Jackson Group sandstones are trapped predominantly by porosity changes as a result of updip stratigraphic pinch-out of barrier-fringe sands. Subtle structural influences such as nosing and small faults also assist in oil entrapment. Intrafield permeability barriers compartmentalize oil reservoirs in Charco Redondo field.

5. Swelling smectite clays occur within Jackson Group reservoir sandstones. When exposed to fresh water, smectite clays will swell and could potentially interfere with reservoir performance by reducing permeability.

6. Deep geothermal fairways in South Texas contain geopressured-geothermal brines having temperatures locally that exceed $350^{\circ} \mathrm{F}\left(177^{\circ} \mathrm{C}\right)$, but they are characterized by low permeability, which would limit their productivities.

7. Upper Wilcox geopressured-geothermal reservoirs in South Texas will not produce brine at the rate of $20,000 \mathrm{bbl} / \mathrm{d}\left(0.037 \mathrm{~m}^{3} \mathrm{~s}^{-1}\right)$, which occurred from the Frio Formation at the Pleasant Bayou geothermal test well in Brazoria County. However, production rates of approximately 1,000 to $2,000 \mathrm{bbl} / \mathrm{d}\left(\sim 1.8 \times 10^{-3} \mathrm{~m}^{3} \mathrm{~s}^{-1}\right.$ to $3.7 \times$ $10^{-3} \mathrm{~m}^{3} \mathrm{~s}^{-1}$ ) have been demonstrated in a production test from the upper Wilcox at Riddle No. 2 Saldana in Zapata County, South Texas. Such rates may be adequate to (1) test the technology for geothermally enhanced oil recovery, (2) determine engineering data on South Texas geothermal reservoirs, and (3) study interactions between geothermal fluids and heavy-oil reservoirs. 


\section{Acknowledgments}

This work was supported by the U.S. Department of Energy under Cooperative Agreement No. DE-FC07$85 N V 10412$ and managed through the Idaho National Engineering Laboratory Geopressured-Geothermal Program. We thank the following individuals and organizations for their assistance: Mark Miller, Petroleum Engineering Department, The University of Texas at Austin; Ray Fortuna, U.S. Department of Energy, Washington, D.C.; Jane Negus-de Wys, Idaho National Engineering Laboratory; Charles Kimmell, Fanion Production Company; and Shell Exploration and Production Company. We wish to acknowledge two individuals who initially recognized the potential for geothermal energy production - the late Myron Dorfman (who was named the W. A. Moncrief, Jr., Centennial Endowed Chair in Petroleum Engineering at The
University of Texas at Austin) and William L. Fisher (current Director of the Bureau of Economic Ceology). Dr. Jane Negus-de Wys has supported, encouraged, and promoted the direct use of geothermal fluids for thermally enhanced oil recovery.

Technical editing was by Tucker F. Hentz. Jay A. Raney, H. Scott Hamlin, Mary L. W. Jackson, W. R. Kaiser, and Paul R. Knox reviewed the manuscript. Michele Bailey, Susan Krepps, Patrice A. Porter, Kerza A. Prewitt, and Tari Weaver drafted the figures under the supervision of Richard L. Dillon, chief cartographer. Others contributing to the publication of this circular were David M. Stephens, text illustration photography; Susan Lloyd, word processing and typesetting; Bobby Duncan, editing; Margaret L. Evans, design; and Kitty Challstrom and Jeannette Miether, proofreading.

\section{References}

Ball Associates, Ltd., 1965, Surface and shallow oilimpregnated rocks and shallow oil fields in the United States: U.S. Bureau of Mines Monograph 12, 375 p.

Barker, B. J., Gulati, M. S., Bryan, M. A., and Riedel, K. L., 1991, Geysers reservoir performance: Geo-Heat Center Quarterly Bulletin, v. 13, no. 3, p. 1-14.

Bebout, D. C., Agagu, O. K., and Dorfman, M. H., 1975a, Geothermal resources_-Frio Formation, middle Texas Gulf Coast: The University of Texas at Austin, Bureau of Economic Geology Geological Circular 75-8, 43 p.

Bebout, D. G., and Bachman, A. L., 1981, eds., Proceedings, Fifth U.S. Gulf Coast Geopressured-Geothermal Energy Conference: Baton Rouge, Louisiana State University, $343 \mathrm{p}$.

Bebout, D. G., Dorfman, M. H., and Agagu, O. K., 1975b, Geothermal resources-Frio Formation, South Texas: The University of Texas at Austin, Bureau of Economic Geology Geological Circular 75-1, 36 p.

Bebout, D. G., and Gutierrez, D. R., 1981, Geopressured geothermal resource in Texas and Lovisiana-geological constraints, in Bebout, D. G., and Bachman, A. L., eds., Proceedings, Fifth U.S. Gulf Coast GeopressuredGeothermal Energy Conference: Baton Rouge, Louisiana State University, p. 13-28.

Bebout, D. G., Loucks, R. G., Bosch, S. C., and Dorfman, M. H., 1976, Geothermal resources-Frio Formation, upper Texas Gulf Coast: The University of Texas at Austin, Bureau of Economic Geology Geological Circular 76-3, $47 \mathrm{p}$.

Bebout, D. G., Loucks, R. G., and Gregory, A. R., 1978, Frio sandstone reservoirs in the deep subsurface along the
Texas Gulf Coast: their potential for production of geopressured geothermal energy: The University of Texas at Austin, Bureau of Economic Geology Report of Investigations No. 91, 93 p.

Bebout, D. G., Weise, B. R., Gregory, A. R., and Edwards, M. B., 1982, Wilcox sandstone reservoirs in the deep subsurface along the Texas Gulf Coast: their potential for production of geopressured geothermal energy: The University of Texas at Austin, Bureau of Economic Geology Report of Investigations No. 117, 125 p.

Blount, C. W., Price, L. C., Wenger, L. M., and Tarullo, M., 1979, Methane solubility in aqueous $\mathrm{NaCl}$ solutions at elevated temperatures and pressures: Idaho State University and U.S. Geological Survey, progress report prepared for the U.S. Department of Energy under contract no. ET-78-S-07-1716, 38 p.

Bodner, D. P., Blanchard, P. E., and Sharp, J. M., Jr., 1985, Variations in Gulf Coast heat flow created by groundwater flow: Gulf Coast Association of Geological Societies Transactions, v. 35, p. 19-27.

Bruce, C. H., 1973, Pressured shale and related sediment deformation: mechanism for development of regional contemporaneous faults: American Association of Petroleum Geologists Bulletin, v. 53, no. 1, p. 73-93.

Burger, Jacques, Sourieau, Pierre, and Combarnous, Michael, 1985, Thermal methods of oil recovery: Paris, France, Editions Technip; Gulf Publishing Company, Book Division, $430 \mathrm{p}$.

Clark, J. D., 1985, Engineering interpretation of exploration drawdown tests, lower Miocene geopressured-brine reservoirs, T-F\&S/DOE Gladys McCall No. 1 well, Cameron Parish, Louisiana, in Dorfman, $M$. H., and 
Morton, R. A., eds., Proceedings, Sixth U.S. Gulf Coast Geopressured-Geothermal Energy Conference: New York, Pergamon Press, p. 23-46.

Craig, F. F., Jr., 1971, The reservoir engineering aspects of water flooding: Society of Petroleum Engineers, Monograph Series, v. 3, 141 p.

Dietz, D. N., 1972, Hot-water drive, in Thermal recovery techniques: Richardson, Texas, Society of Petroleum Engineers, Reprint Series, no. 10, p. 79-85.

Dodge, M. M., and Posey, J. S., 1981, Structural cross sections, Tertiary formations, Texas Gulf Coast: The University of Texas at Austin, Bureau of Economic Geology cross sections.

Dorfman, M. H., and Deller, R. W., 1975, eds., Proceedings, First U.S. Gulf Coast Geopressured-Geothermal Energy Conference: The University of Texas at Austin, report prepared for the U.S. Energy Research and Development Administration, $362 \mathrm{p}$.

1976, eds., Proceedings, Second U.S. Gulf Coast Geopressured-Geothermal Energy Conference: The University of Texas at Austin, report prepared for the U.S. Energy Research and Development Administration under contract no. E (40-1) 49(), 369 p.

Dorfman, M. H., and Fisher, W. L., 1979, eds., Proceedings, Fourth U.S. Gulf Coast Geopressured-Geothermal Energy Conference: The University of Texas at Austin, report prepared for the U.S. Department of Energy, 1692 p.

Dorfman, M. H., and Kehle, R. O., 1974, Potential geothermal resources of Texas: The University of Texas at Austin, Bureau of Economic Geology Ceological Circular 77-4, $33 \mathrm{p}$.

Dorfman, M. H., and Morton, R. A., 1985, eds., Proceedings, Sixth U.S. Gulf Coast Geopressured-Ceothermal Energy Conference: New York, Pergamon Press, 344 p.

DuBar, J. R., 1990, Hot-water flooding: its role in the mobilization of heavy oil, in Raney, J. A., project director, Consolidation of geologic studies of geopressuredgeothermal resources in Texas: The University of Texas at Austin, Bureau of Economic Geology, open-file report prepared for the U.S. Department of Energy under contract no. DE-FC07-85NV10412, p. 39-61.

Durrett, L. R., 1985, Results of long-term testing of a geopressured-geothermal design well, T-F\&S/DOE Gladys McCall No. 1, in Dorfman, M. H., and Morton, R. A., 1985, eds., Proceedings, Sixth U.S. Gulf Coast Geopressured-Ceothermal Energy Conference: New York, Pergamon Press, p. 11-22.

Eaton Operating Company, 1991, Contract performance report, October, 1991: Houston, Texas, report prepared for the U.S. Department of Energy under contract no. DEAC07-85ID12578, 70 p.

Edwards, M. B., 1981, Upper Wilcox Rosita delta system of South Texas: growth-faulted shelf-edge deltas: American Association of Petroleum Geologists Bulletin, v. 65, p. 54-73.

Ewing, T. E., 1983, Jackson-Yegua barrier/strandplain sandstone, in Galloway, W. E., Ewing, T. E., Garrett,
C. M., Tyler, Noel, and Bebout, D. G., Atlas of major Texas oil reservoirs: The University of Texas at Austin, Bureau of Economic Geology Special Publication, p. 30 32.

1986, Structural styles of the Wilcox and Frio growth-fault trends in Texas: constraints on geopressured reservoirs: The University of Texas at Austin, Bureau of Economic Geology Report of Investigations No. 154, $86 \mathrm{p}$.

Fertl, W. H., Chilingarian, G. V., and Rieke, H. H., III, 1976, Abnormal formation pressures: New York, Elsevier, $382 \mathrm{p}$.

Fisher, W. L., Proctor, C. V., Jr., Galloway, W. E., and Nagle, J. S., 1970, Depositional systems in the Jackson Group of Texas-their relationship to oil, gas, and uranium: Gulf Coast Association of Ceological Societies Transactions, v. 20, p. 234-261.

Galloway, W. E., Ewing, T. E., Garrett, C. M., Tyler, Noel, and Bebout, D. G., 1983, Atlas of major Texas oil reservoirs: The University of Texas at Austin, Bureau of Economic Geology Special Publication, $139 \mathrm{p}$.

Garg, S. K., and Riney, T. D., 1985, Analysis of flow data from the DOW/DOE L. R. Sweezy No. 1 Well, in Dorfman, M. H., and Morton, R. A., eds., Proceedings, Sixth U.S. Gulf Coast Geopressured-Geothermal Energy Conference: New York, Pergamon Press, p. 71-80.

Gould, T. L., Kenner, C. B., and Clark, J. D., 1981, in Bebout, D. G., and Bachman, A. L., 1981, eds., Proceedings, Fifth U.S. Gulf Coast Geopressured-Ceothermal Energy Conference: Baton Rouge, Louisiana State University, p. 317-324.

Gregory, A. R., Dodge, M. M., Posey, J. S., and Morton, R. A., 1980, Volume and accessibility of entrained (solution) methane in deep geopressured reservoirsTertiary formations of the Texas Gulf Coast: The University of Texas at Austin, Bureau of Economic Geology, openfile report prepared for the U.S. Department of Energy under contract no. DE-AC08-78ET11397, $390 \mathrm{p}$.

Hamlin, H. S., Walter, T. G., and Kreitler, C. W., 1989, Colocation of heavy oil and geopressured-geothermal brine resources: examples from South Texas and Kern County, California, in Kreitler, C. W., project director, Consolidation of geologic studies of geopressuredgeothermal resources in Texas: The University of Texas at Austin, Bureau of Economic Geology, open-file report prepared for the U.S. Department of Energy under contract no. DE-FC07-85NV10412, p. 187-241.

Hannah, J. L., 1975, The potential of low temperature geothermal resources in northern California: California Department of Conservation, Division of Oil and Gas, Geothermal Unit, 53 p.

Hopf, R. W., 1986, Cole field re-entered, Duval and Webb Counties, Texas, in Stapp, W. L., ed., Contributions to the geology of South Texas: San Antonio, South Texas Geological Society, p. 83-99.

Hughes, E. E., and Campbell, R. G., 1985, Hybrid power system for Pleasant Bayou geopressured well, in Dorfman, 
M. H., and Morton, R. A., eds., Proceedings, Sixth U.S. Gulf Coast Geopressured-Geothermal Energy Conference: New York, Pergamon Press, p. 251-257.

Hyatt, D. B., 1990, Geology and production characteristics of the Seventy-Six West field, Duval County, Texas: Gulf Coast Association of Geological Societies Transactions, v. 40, p. 305-318.

Interstate Oil Compact Commission, 1984, Major tar sand and heavy oil deposits of the United States: Oklahoma City, Oklahoma, 272 p.

Jones, P. H., 1976, Natural gas resources of the geopressured zones in the northern Gulf of Mexico basin, in Natural gas from unconventional geologic sources: National Research Council, Board of Mineral Resources, Commission on Natural Resources, National Academy of Sciences, p. 17-33.

Kaiser, W. R., Ayers, W. B., Jr., and La Brie, L. W., 1980, Lignite resources in Texas: The University of Texas at Austin, Bureau of Economic Geology Report of Investigations No. 104, 52 p.

Kaiser, W. R., Johnston, J. E., and Bach, W. N., 1978, Sandbody geometry and the occurrence of lignite in the Eocene of Texas: The Universit, of Texas at Austin, Bureau of Economic Geology Geological Circular 78-4, 19 p.

Kehle, R. O., 1971, Geothermal survey of North America, 1971 annual progress report: Research Committee, American Association of Petroleum Geologists (unpublished), $31 \mathrm{p}$.

King, R. L., and Lee, W. J., 1976, An engineering study of the Hawkins (Woodbine) field: Journal of Petroleum Technology, v. 28, p. 123-128.

Klauzinski, R. Z., 1981, Testing of six "Wells of Opportunity" during 1980 and 1981, in Bebout, D. G., and Bachman, A. L., eds., Proceedings, Fifth U.S. Gulf Coast Geopressured-Geothermal Energy Conference: Baton Rouge, Louisiana State University, p. 171-176.

Lane, E. C., and Garton, E. L., 1925, "Base" of a crude oil: U.S. Bureau of Mines, Report of Investigations 3279, $12 \mathrm{p}$.

Lewis, C. R., and Rose, S. C., 1970, A theory relating high temperatures to overpressures: Journal of Petroleum Technology, v. 22, p. 11-16.

Lombard, D. B., 1985, Geopressured geothermal brines-a resource for the future, in Dorfman, M. H., and Morton, R. A., eds., Proceedings, Sixth U.S. Gulf Coast Geopressured-Geothermal Energy Conference: New York, Pergamon Press, p. 3-7.

Loucks, R. G., 1979, Sandstone distribution and potential for geopressured geothermal energy production in the Vicksburg Formation along the Texas Gulf Coast: The University of Texas at Austin, Bureau of Economic Geology Geological Circular 79-4, 33 p.

Loucks, R. G., Dodge, M. M., and Galloway, W. E., 1980, Importance of secondary leached porosity in lower Tertiary sandstone reservoirs along the Texas Gulf Coast: The University of Texas at Austin, Bureau of Economic Geology Geological Circular 80-2, 8 p.
Loucks, R. G., Richman, D. L., and Milliken, K. L., 1981, Factors controlling reservoir quality in Tertiary sandstones and their significance to geopressured geothermal production: The University of Texas at Austin, Bureau of Economic Geology Report of Investigations No. 111, $41 \mathrm{p}$.

Lunis, B. C., 1990, Geopressured-geothermal direct use potentials are significant: Geo-Heat Center Quarterly Bulletin, v. 12, no. 2, p. 1-7.

Lunis, B. C., Negus-de Wys, Jane, Plum, M. M., Lienau, P. J., Spencer, F. J., and Nitschke, G. F., 1991, The feasibility of applying geopressured-geothermal resources to direct uses: EG\&G Idaho, Idaho National Engineering Laboratory, EGG-EP-9839, 58 p.

Martin, W. L., Dew, J. N., Powers, M. L., and Steves, H. B., 1972, Results of a Tertiary hot waterflood in a thin sand resenvoir, in Thermal recovery techniques: Richardson, Texas, Society of Petroleum Engineers, Reprint Series, no. 10, p. 97-110.

McCulloh, R. P., and Piño, M. A., 1981, Ceopressured geothermal resource potential of Miocene Bayou Hebert Prospect, Vermilion and Iberia Parishes, Louisiana, in Bebout, D. G., and Bachman, A. L., eds., Proceedings, Fifth U.S. Gulf Coast Geopressured-Geothermal Energy Conference: Baton Rouge, Louisiana State University, p. 237-240.

Meriwether, John, ed., 1977, Proceedings, Third U.S. Gulf Coast Geopressured-Geothermal Energy Conference: Lafayette, Louisiana, The University of Southwestern Louisiana, report prepared for the U.S. Department of Energy under contract no. EG-77-G-05-5557, variously paginated.

Milliken, K. L., Land, L. S., and Loucks, R. G., 1981, History of burial diagenesis determined from isotopic geochemistry, Frio Formation, Brazoria County, Texas: American Association of Petroleum Geologists Bulletin, v. 65, no. 8, p. 1397-1413.

Morton, R. A., 1981, Pleasant Bayou No. 2-A review of rationale, ongoing research and preliminary test results, in Bebout, D. G., and Bachman, A. L., eds., Proceedings, Fifth U.S. Gulf Coast Ceopressured-Geothermal Energy Conference: Baton Rouge, Louisiana State University, p. 55-58.

Morton, R. A., Ewing, T. E., and Tyler, Noel, 1983, Continuity and intemal properties of Gulf Coast sandstones and their implications for geopressured fluid production: The University of Texas at Austin, Bureau of Economic Ceology Report of Investigations No. 132, 70 p.

Negus-de Wys, Jane, 1990, eds., Proceedings, Industrial Consortium for the Utilization of the GeopressuredGeothermal Resource: EC\&G, Inc., Idaho National Engineering Laboratory, Idaho Falls, Idaho, 2 vols.

1991, ed., Proceedings, Industrial Consortium for the Utilization of the Geopressured-Geothermal Resource: EG\&G, Inc., Idaho National Engineering Laboratory, Idaho Falls, Idaho, 2 vols.

Negus-de Wys, Jane, Kimmell, C. E., Hart, G. F., and Plum, M. M., 1991, The feasibility of recovering medium to 
heavy oil using geopressured-geothermal fluids: EG\&G Idaho, Idaho National Engineering Laboratory, EGG-EP. 9840, 107 p.

North, F. K., 1985, Petroleum geology: Unwin Hyman, Winchester, Massachusetts, 631 p.

Peterson, K. P., 1981, Structural geology of Wells of Opportunity" tested during 1980 and 1981, in Bebout, D. G., and Bachman, A. L., eds., Proceedings, Fifth U.S. Gulf Coast Geopressured-Geothermal Energy Conference: Baton Rouge, Louisiana State University, p. 163-170.

Philippi, G. T., 1977, On the depth, time, and mechanism of origin of the heavy- to medium-gravity naphthenic crude oils: Geochimica et Cosmochimica Acta, v. 41, no. 1, p. 33-52.

Podio, A. L., Gray, K. E., Isokrari, O. F., Knapp, R. M., Silberberg, I. H., and Thompson, T. W., 1976, Reservoir research and technology, in Reservoir research and technology, Proceedings, Second GeopressuredGeothermal Energy Conference, The University of Texas at Austin, Center for Energy Studies, v. 3, part 1, p. 54 56.

Prats, Michael, 1986, Thermal recovery: Richardson, Texas, Society of Petroleum Eng: ineers, 283 p.

Pritchett, J. W., and Riney, T. D., 1985, Analysis of the T-F\&S/DOE Gladys McCall No. 1 Well test results and history matching simulations for sand zone no. 8, in Dorfman, M. H., and Morton, R. A., eds., Proceedings, Sixth U.S. Gulf Coast Geopressured-Geothermal Energy Conference: New York, Pergamon Press, p. 47-56.

Riggs, S. R., Ellison, S. P., Jr., Fisher, W. L., Galloway, W. E., Jackson, M. L. W., and Morton, R. A., 1991, Mineral resources and geopressured-geothermal energy, in Salvador, A., ed., The Gulf of Mexico Basin: Geological Society of America, The geology of North America, v. J, chapter 16, p. 495-527.

Rodgers, J. S., Coble, Larry, and Hamilton, J. R., 1985, Analyses of DOW/DOE No. 1 L. R. Sweezy well tests, in Dorfman, M. H., and Morton, R. A., eds., Proceedings, Sixth U.S. Gulf Coast Geopressured-Geothermal Energy Conference: New York, Pergamon Press, p. 57-70.

Rodgers, R. W., and Durham, C. O., Jr., 1985, The Sweet Lake geopressured-geothermal project, Cameron Parish, Louisiana-final summary and analysis, in Dorfman, M. H., and Morton, R. A., eds., Proceedings, Sixth U.S. Gulf Coast Geopressured-Geothermal Energy Conference: New York, Pergamon Press, p. 93-103.

Schultz, A. L., 1986, Geology of the first Mirando Sand, South Lopez Unit, Lopez field, Webb and Duval Counties, Texas, in Stapp, W. L., ed., Contributions to the geology of South Texas: San Antonio, South Texas Geological Society, p. 100-108.

Seni, S. J., and Walter, T. G., 1990, Colocation of geothermal and heavy-oil reservoirs: a South Texas update, in Raney, J. A., project director, Consolidation of geologic studies of geopressured-geothermal resources in Texas: The
University of Texas at Austin, Bureau of Economic Geology, open-file report prepared for the U.S. Department of Energy under contract no. DE-FCO785NV10412, p. 1-37.

Smith, H. M., 1968, Crude oil: qualitative and quantitative aspects - the petroleum world: U.S. Bureau of Mines Bulletin 642, $125 \mathrm{p}$.

Snyder, F. C., and Pilger, R. H., Jr., 1981, Structuralstratigraphic setting of Lafourche Crossing prospect, Louisiana, in Bebout, D. G., and Bachman, A. L., 1981, eds., Proceedings, Fifth U.S. Gulf Coast GeopressuredGeothermal Energy Conference: Baton Rouge, Louisiana State University, p. 233-236.

Swanson, R. K., Oetking, P., Osoba, J. S., and Hagens, R. C., 1976, Development of an assessment methodology for geopressured zones of the Upper Gulf Coast based on a study of abnormally pressured gas fields in South Texas: San Antonio, Southwest Research Institute, report prepared for the U.S. Energy Research and Development Administration under contract no. E (11-1) 2687, 75 p.

Tissot, B. P., and Welte, D. H., 1984, Petroleum formation and occurrence: New York, Springer-Verlag, 699 p.

Tyler, Noel, Galloway, W. E., Garrett, C. M., Jr., and Ewing, T. E., 1984, Oil accumulation, production characteristics, and targets for additional recovery in major oil reservoirs of Texas: The University of Texas at Austin, Bureau of Economic Geology Geological Circular 84-2, 31 p.

Tyler, Noel, Holtz, M. H., Garrett, C. M., Jr., and White, W. G., 1991, Atlas of major Texas oil reservoirs: data base: The University of Texas at Austin, Bureau of Economic Ceology computerized data base.

Wallace, R. H., Kraemer, T. F., Taylor, R. E., and Wesselman, J. B., 1979, Assessment of geopressured-geothermal resources in the northern Gulf of Mexico basin, in Muffler, L. J. P., ed., Assessment of geothermal resources in the United States-1978: U.S. Geological Survey Circular 790, p. 132-155.

West, T. S., 1963, Typical stratigraphic traps, Jackson trend of South Texas: Gulf Coast Association of Geological Societies Transactions, v. 13, p. 67-78.

Winker, C. D., Morton, R. A., Ewing, T. E., and Garcia, D. D., 1983, Depositional setting, structural style, and sandstone distribution in three geopressured geothermal areas, Texas Gulf Coast: The University of Texas at Austin, Bureau of Economic Geology Report of Investigations No. $134,60 \mathrm{p}$.

Woodruff, C. M., 1982, Geothermal resources of Texas: The University of Texas at Austin, Bureau of Economic Geology Energy and Mineral Resources Maps, scale $1: 1,000,000$.

Wrighton, Fred, 1981, An economic overview of geopressured solution gas, in Bebout, D. G., and Bachman, A. L., eds., Proceedings, Fifth U.S. Gulf Coast Geopressured-Geothermal Energy Conference: Baton Rouge, Louisiana State University, p. 45-48. 


\section{Appendix 1: Medium- and Heavy-Oil Reservoirs}

Eiqure 15

lackson-Yegua Barrier/Strandplain

1. Lundell

2. Seven Sisters

3. Aviators

4. Govt. Wells N

5. Govt. Wells $S$

6. Mirando City

7. Lopez

8. Piedre Lumbre

9. Escobas

10. Hoffman

\section{Cap Rock}

11. Humble Cap Rock

12. Sour Lake Cap Rock

13. Spindletop Cap Rock

\section{Piercement Salt Dome}

14. Big Creek

15. Port Neches

16. Damon Mound

17. Clam Lake

18. Barbers Hill

19. Fannett

20. Markham

Woodbine Fluvial/Deltaic/Strandplain

21. Hawkins

Paluxy Fault Line

22. Pewitt Ranch

23. Sulphur Bluff

24. Talco

\section{Fiqure 18}

Heavy-oil fields (reservoirs)

1. Alworth (Cole sand)

2. Bruni $S$

3. Bruja Vieja (Cole sand)

4. Cedro Hill

5. Charco Redondo

6. Colmena

7. Dinn

8. Edlasater W (Cole 950)

9. El Puerto $N\left(O^{\prime} \mathrm{Hem}\right)$

10. Govt. Wells $\mathbf{N}(900$ sand)

11. Govt. Wells N (1000 sand)

12. Govt. Wells N (1150)

13. Govt Wells $N(1550)$

14. Govt. Wells $S$ (1900)

15. Hoffman E

16. Joe Moss (500 sand)

17. Kohler NE (Mirando No. 2)

18. Las Animas-Lefevre

19. Lopez N (Lopez)

20. Lundell

21. Orlee

22. Peters $N$ (first Cole sand)

23. Rancho Solo

24. Rancho Solo (second Cole sand)

25. Rancho Solo (extension)

26. Richardson
Large oil fields
A. Aviators
B. Colorado
C. Conoco Driscoll
D. Escobas
E. Govt. Wells N
F. Govt. Wells S
G. Hoffman
H. Loma Novia
l. Lopez
J. Lundell
K. Mirando City
L. O'Hem
M. Piedre Lumbre
N. Prado
O. Seven Sisters 


\section{Appendix 2: Wells on Cross Sections}

Figure 21 (A-A)

1. ZA-406

2. DU-126 Royal Oil and Gas No. 1-R F. Lowe Bindewald

Figure $23(B-B)$

1. ZA-364

2. ZA-394

3. ZA-359

4. ZA-357

5. ZA-349

6. ZA-418

7. ZA-338

8. ZA-334

9. ZA-410

10. ZA-406

11. ZA-413

Delaney Oil and Gas No. 3 A. de Vela

Moss No. 1 Vela

Moss No. 3 Vela

Florence E. Green No. 1 Mission Prod.

Moss and Watson No. 6 Vela

Suburban Propane No. 1 Trevino

DeLange and Fallis No. 2 P. Trevino

Schwab et al. No. 1-B A. Garcia

Guardian No. 1 A. Garcia

Southland Royalty No. 2 A. Garcia

Allen No. 1 A. Garcia

Figure 24 (A-A)

1. ZA-406

Southland Royalty No. 2 A. Garcia

2. $\mathrm{H}-37$

3. $\mathrm{JH}-34$

Humble Oil and Refining No. 1 Colorado GU 1

4. DU-78

Cox and Cox No. 1 A. Martinez

5. DU-89

Union Producing Co. No. 1 Brennan-Benavides

6. DU-59

Getty (Texaco) No. 1 V. K. Gruy

7. DU-146

Floumoy et al. No. 1 Cuellar Brothers

8. DU-126

Shell Oil No. 2 A. R. Hubbard GU 1

Royal Oil and Gas No. 1-R F. Lowe Bindewald

Figure $28(C-C)$

1. $\mathrm{H}-1$

2. $\mathrm{JH}-3$

Shell Oil No. 1 J. E. Fulbright

3. $\mathrm{JH}-15$

Austral No. 2 Marrs McLean

4. $\mathrm{JH}-34$

Atlantic Richfield No. C-4 Marrs McLean Trust

5. $\mathrm{H}-334$

Cox and Cox No. 1 A. Martinez

6. $\mathrm{JH}-324$

Coastal Well Service No. 1 Felix Stroman

7. $\mathrm{JH}-326$

Humble Oil and Refining No. 2 Moody Ranch

Humble Oil and Refining No. 1-D Mostena Oil and Gas

Figure 29

1. T-225-C

2. ZA-330

Texaco No. T-225-C Charco Redondo

3. $\mathrm{ZA}-310$

Schwab et al. No. 3 Flores

Miller and Pierce No. 1 E. J. Flores et al.

Figure 32

1. T-180-D Texaco No. T-180-D Charco Redondo

2. T-180-C Texaco No. T-180-C Charco Redondo

3. T-180-B Texaco No. T-180-B Charco Redondo

4. T-180-A Texaco No. T-180-A Charco Redondo

5. T-O-A Texaco No. T-O-A Charco Redondo

6. T-O-B Texaco No. T-O-B Charco Redondo

7. T-O-C Texaco No. T-O-C Charco Redondo 


\section{Appendix 3. Abandoned Deep Gas Wells in South Texas}

\begin{tabular}{|c|c|c|c|c|}
\hline $\begin{array}{c}\text { Well } \\
\text { number }\end{array}$ & $\begin{array}{c}\text { BEG } \\
\text { number }\end{array}$ & Well name & Field name & Reservoir \\
\hline 1 & DU.50 & Harkins No. 1-A Garza-Cuellar & Los Reyes & Weatherby sand \\
\hline 2 & DU-65 & Eason-Harper No. 1-160 Peters Estate & Peters S & Wilcox \\
\hline 3 & DU-66 & Eason No. 1 Peters Estate & Peters S & Wilcox \\
\hline 4 & DU-81 & K. P. Exploration No. 2 Wm. Hubberd & Leedy & Wilcox B \\
\hline 5 & DU-82 & Exxon No. 1 Bravo Land Co. & Rejeletta S & 10,000 sand \\
\hline 6 & DU-83 & Harkins and Co. No. 1 La Venada & La Venada & Weatherby \\
\hline 7 & DU-85 & Shell No. 1 J. F. Welder Heirs & Bold Forbes & Carrizo $P$ \\
\hline 8 & DU-96 & Marine Contractors et al. No. 1 Hall-Weiderkehr & Govt. Wells & Mirando \\
\hline 9 & DU-97 & Fair and Woodwand No. 1 J. Luptack & East 76 & Wilcox \\
\hline 10 & DU-99 & Harkins and Co. No. 1-100 D.C.R.C. & Govt. Wells & \\
\hline 11 & DU-105 & Harkins and McDonald No. 2 D.C.R.C. & Piedre Lumbre & Wilcox W \\
\hline 12 & DU-110 & Exxon No. 2-H D.C.R.C. & Petrox & Wilcox 7100 \\
\hline 13 & DU-124 & Inland Ocean No. 1 Ross & Labbe $S$ & Wilcox Upper \\
\hline 14 & DU-126 & Royal Oil and Gas No. 1-R F. Lowe Bindewald & Hostetter S & Wilcox 10,200 \\
\hline 15 & DU-132 & Harkins and Co. No. 1 A. S. Serna & Los Reyes & Weatherby sand \\
\hline 16 & DU-141 & Shell No. 1 J. S. Garcia & Rosita NW & Wilcox S-8 \\
\hline 17 & DU-153 & Tana Oil No. 1 Hahl & & \\
\hline 18 & DU.158 & T. D. Exploration No. 1 De la Fuente & Herbst-Wilcox & Herbst III \\
\hline 19 & WE-2 & Houston Oil and Minerals No. 1 F. Billings & Lopez W & Floyd-A \\
\hline 20 & WE-16 & Hughes and Hughes No. A-1 O. Laurel & Tom Sherman & 10500 \\
\hline 21 & WE-49 & E. P. Operating Co. No. 2 A. Z. Laurel & El Milagro & Seventh Hinnan \\
\hline 22 & WE-52 & Forest Oil No. 1 Rosa V. de Benavides & Cole W & Wilcox \\
\hline 23 & WE-56 & Conoco No. 1 Carlos Benavides & Picoso & Wilcox 10,300 \\
\hline 24 & WE-58 & Conoco No. B-3 Carlos Benavides & Picoso & Wilcox 11,800 \\
\hline 25 & WE-59 & Conoco No. A-2 Alicia Henry-BMT & Perdido & Taylor Lobo \\
\hline 26 & WE-60 & Conoco No. A-1 Alicia Henry-BMT & Perdido & Taylor Lobo \\
\hline 27 & WE-65 & Sagex No. 1 C. B. Dickenson & Picoso $\mathrm{E}$ & Carrizo 8000 \\
\hline 28 & WE-67 & Aminoil USA No. 2 Moglia & Moglia & 11200 \\
\hline 29 & WE-68 & Forest Oil No. 1 G. C. Villareal GU & Oilton $N$ & 10600 \\
\hline 30 & $\mathrm{JH}-25$ & Pan American Sales Corp. No. 3 Gutierrez & Travis Ward & First Hinnant \\
\hline 31 & $\mathrm{JH}-34$ & Cox and Cox No. 1 A. Martinez & Petroleo & Wilcox \\
\hline 32 & ZA-17 & Blocker No. 252 Hinnant & Toquachie Creek & \\
\hline 33 & $Z A-41$ & Pennzoil Production No. 1 A. R. Gutierrez & Jennings $S$ & Wilcox 8550 \\
\hline 34 & $Z A-46$ & Houston Oil and Minerals No. 1 Asche & Charco & 9100 \\
\hline 35 & ZA-60 & Pennzoil Production No. 1 A. Vela & Comitas SW & 7000 \\
\hline 36 & ZA-63 & Samedan Oil No. 1 Maties Unit & Cinco de Mayo & 10150 \\
\hline 37 & ZA-82 & Pennzoil Production No. I C-1 A. Vela & El Grullo & 6760 \\
\hline 38 & ZA-85 & Pennzoil Production No. 1 P. Gonzales Vela & El Grullo & 7300 \\
\hline 39 & ZA-88 & Texas Oil and Gas Corp. No. 1 Guerra "M" & Roleta & 6800,7483 \\
\hline 40 & ZA.92 & $\begin{array}{l}\text { Gulf Energy and Minerals U.S. } \\
\text { No. 1-A G. Gonzalez }\end{array}$ & Falcon Lake $\mathrm{N}$ & Wilcox 6400 \\
\hline 41 & ZA-100 & Good Hope Refineries No. I Falcon & Onepol & Wilcox Upper \\
\hline 42 & ZA-130 & Hughes and Hughes No. G-1 L. A. Hinnant & Aviators S & 11800 \\
\hline
\end{tabular}




\section{Appendix 3 (cont.)}

\begin{tabular}{|c|c|c|}
\hline $\begin{array}{c}\text { Well } \\
\text { number }\end{array}$ & $\begin{array}{c}\text { BEG } \\
\text { number }\end{array}$ & Well name \\
\hline 43 & ZA-132 & Hughes and Hughes No. M-1 Hinnant \\
\hline 44 & ZA-140 & Shell Oil No. I L. Taylor \\
\hline 45 & ZA-146 & Shell Oil No. 1 G. G. Hinojosa \\
\hline 46 & ZA-150 & Shell Western E and P No. A-2 H. B. Zachry \\
\hline 47 & $Z A-151$ & Shell Oil No. 3 Muzza \\
\hline 48 & ZA-153 & Shell Oil No. 2 L. Garza et al. \\
\hline 49 & ZA-156 & Shell Oil No. 3 M. T. Longoria \\
\hline 50 & ZA-160 & Killam and Hurd No. 2 E. Vela \\
\hline 51 & ZA-170 & Pennzoil Production No. 1 A. Garcia \\
\hline 52 & ZA-181 & Blocker Explor. No. 1-112 L. A. Hinnant \\
\hline 53 & ZA-184 & Entex Petroleum No. 1 A. M. Vela \\
\hline 54 & ZA-185 & Gulf Oil No. 1 Saldana Unit \\
\hline 55 & ZA-190 & Canus Petroleum No. 1 San Miguel et al. \\
\hline 56 & ZA-199 & Gulf Oil No. 1 Vela de Peña \\
\hline 57 & ST-12 & [ order No. 2 N. Silva \\
\hline
\end{tabular}

\begin{tabular}{|c|c|}
\hline Field name & Reservoir \\
\hline Aviators S & Wilcox 11050 \\
\hline El Grullo E & Taylor sand \\
\hline \multicolumn{2}{|l|}{ Fandango } \\
\hline Fandango & Wilcox Upper T6 \\
\hline Fandango & Wilcox Upper T6 \\
\hline \multicolumn{2}{|l|}{ Fandango } \\
\hline Randado Ranch & Queen City \\
\hline \multicolumn{2}{|l|}{ Wildcat } \\
\hline Volpe SE & Wilcox 7730 \\
\hline Toquachie Creek & Wilcox \\
\hline Herlinda Vela & Wilcox \\
\hline Martinez & $\begin{array}{l}\text { First Hinnant } \\
\text { Upper }\end{array}$ \\
\hline Cuellar & 9215 \\
\hline Cinco de Mayo & 8500 \\
\hline Falcon Dam & Wilcox \\
\hline
\end{tabular}

